\title{
GEOLOGY AND GEOCHEMISTRY OF THE REDROCK GRANITE AND ANORTHOSITE XENOLITHS (PROTEROZOIC) IN THE NORTHERN BURRO MOUNTAINS, GRANT COUNTY, NEW MEXICO, USA
}

\author{
VIRGINIA T. MCLEMORE, NELIA DUNBAR, PAULA J. KOSUNEN, \\ O. TAPANI RÄMÖ, MATT HEIZLER AND ILMARI HAAPALA
}

McLEMORE, VIRGINIA T., DUNBAR, NELIA, KOSUNEN, PAULA J., RÄMÖ, O. TAPANI, HEIZLER, MATT, and HAAPALA, ILMARI 2002. Geology and geochemistry of the Redrock Granite and anorthosite xenoliths (Proterozoic) in the northern Burro Mountains, Grant County, New Mexico, USA. Bulletin of the Geological Society of Finland 74, Parts 1-2, 7-52.

Mineral ages from the A-type granites and anorthosite xenoliths in the Redrock area in the northwestern Burro Mountains in southwestern New Mexico cluster around $\sim 1220-1225 \mathrm{Ma}$ and provide yet another example of bimodal igneous activity during this time period in the southwestern United States. The metaluminous to peraluminous, marginally alkaline to subalkaline Redrock Granite exhibits the textural, mineralogical, and geochemical features of A-type granite that was emplaced at a relatively high crustal level. Field relationships, whole rock and mineral geochemical and isotopic trends suggest that the four phases of the Redrock Granite are genetically related, with the miarolitic biotite/alkali feldspar granite being the youngest phase. Spatial relationships and geochemical data suggest that the anorthosite xenoliths were coeval with the Redrock Granite, which is consistent with the anorthosite being derived from the upper mantle, possibly due to deep mantle upwellings, and the Redrock Granite from the lower crust. The process involved melting in the upper mantle, emplacement of anorthosite in the crust resulting in partial crustal melting and thinning, and, finally, intrusion of shallow silicic plutons, the Redrock Granite. The Redrock Granite and anorthosite were presumably derived from sources characterized by subtle, long-term LREE depletion, with $\varepsilon_{\mathrm{Nd}}($ at $1220 \mathrm{Ma}$ ) values on the order of +1 to +2 .

Key words: granites, A-type granites, anorthosite, xenoliths, geochemistry, chemical composition, electron probe data, isotopes, magmatism, Proterozoic, Burro Mountains, New Mexico, United States

Virginia T. McLemore, Nelia Dunbar, and Matt Heizler: New Mexico Bureau of Geology and Mineral Resources, New Mexico Institute of Mining and Technology, Socorro, NM, 87801, USA

E-mail: ginger@gis.nmt.edu

Paula J. Kosunen, O. Tapani Rämö, and Ilmari Haapala: Department of Geology, P.O. Box 64, FIN-00014 University of Helsinki, Finland 


\section{INTRODUCTION}

Recent studies of Proterozoic rocks in the Burro Mountains in southwestern New Mexico have uncovered several interesting geologic relationships. In the Redrock area of the northwestern Burro Mountains (Fig. 1), there is a spatial association of anorthosites and A-type granites. The bimodal anorthosite-granite association supports current theories involving mantle underplating and partial melting of the lower crust that resulted in intrusion of both types of magmas (Anderson \& Bender 1989, Emslie 1991, Haapala \& Rämö 1990, Rämö \& Haapala 1995). Mineral ages from the Redrock area cluster around $\sim 1220-1225 \mathrm{Ma}$ and it is one of the few areas of bimodal igneous activity during this time period in southwestern United States (Bickford et al. 2000, McLemore et al. 2000a, b). The main goals of our research of the Proterozoic rocks in the Burro Mountains are (1) petrology (protolith history and magmatic evolution) of the granitic plutons, (2) interplay of tholeiitic and potassic mafic magmatism in the petrogenesis of the granitic rocks, (3) Proterozoic geochronology of the Burro Mountains region, and (4) tectonic evolution of southern Laurentia.

The purpose of this paper is to describe the lithology and chemistry of the $\sim 1220$ Ma Redrock Granite and spatially associated anorthosites in the Redrock area of the northern Burro Mountains (Fig. 1). The work reported here builds on results summarized by McLemore et al. (2000b) that briefly described the various rock types and regional geologic setting, in terms of geochemical, isotopic, and geochronological data.

\section{GEOLOGIC SETTING}

The regional structural evolution of the southwestern United States and northern Mexico, specifically the Burro Mountains, has been dominated by a succession of dynamic and sometimes rapidly changing plate tectonic settings from the Proterozoic to the Recent (Coney 1978, Karlstrom \& Bowring 1988, Karlstrom et al. 1990, 2001). This prolonged history of complex continental tecton- ics can be divided into ten phases: (1) Mazatzal orogeny, 1700-1600 Ma (Karlstrom \& Bowring 1988, 1993, Karlstrom et al. 1990), (2) Late Proterozoic granitic plutonism, 1500-1300 Ma (Stacey \& Hedlund 1983, Karlstrom \& Bowring 1988, 1993, Adams \& Keller 1996, Karlstrom et al. 1997, 2001, Karlstrom \& Humphreys 1998), (3) pre-Grenville extension and formation of continental margin at 1300-1260 Ma (Pittenger et al. 1994, Adams \& Keller 1994, 1996, Karlstrom et al. 1997, Karlstrom \& Humphreys 1998, Barnes et al. 1999), (4) 1260-1000 Ma period of mafic and Atype granitic magmatism and volcanic activity in Texas and Arizona, coincident with the Grenville orogeny and perhaps extension (Adams \& Keller 1996, Smith et al. 1997, Shannon et al. 1997, Mosher 1998, Barnes et al. 1999, Reese et al. 2000, McLemore et al. 2000b, Bickford et al. 2000), (5) Paleozoic period of alkaline and carbonatite magmatism and extension at $\sim 500 \mathrm{Ma}$ (McLemore \& McKee 1988b, McLemore et al. 1999a, McMillan et al. 2000), (6) Paleozoic period of basin formation and uplift as part of the Ancestral Rocky Mountains (Florida uplift, Pedregosa Basin; Ross \& Ross 1986), (7) Cretaceous continental arc, shallow marine deposition (Drewes 1991), (8) Laramide compressional deformation and magmatic arc volcanism and plutonism (Late Cretaceous to early Tertiary, Drewes 1991), (9) mid-Tertiary calc-alkaline volcanism to bimodal volcanism with caldera formation (Schoolhouse Mountain caldera related to the Datil-Mogollon field, McIntosh et al. 1991), and (10) late Tertiary-Quaternary Basin and Range extensional deformation (Coney 1978). Each of these tectonic periods left remnant structural trends in the Burro Mountains that were either reactivated or crosscut by younger tectonic events and together have resulted in a structurally complex, relatively thin, brittle, and anisotropic crust in southwestern United States.

The Burro Mountains in southwestern New Mexico comprise a complex Proterozoic terrain that spanned at least from 1633 to $\sim 1000 \mathrm{Ma}$ (Table 1). The Proterozoic rocks include metamorphic 

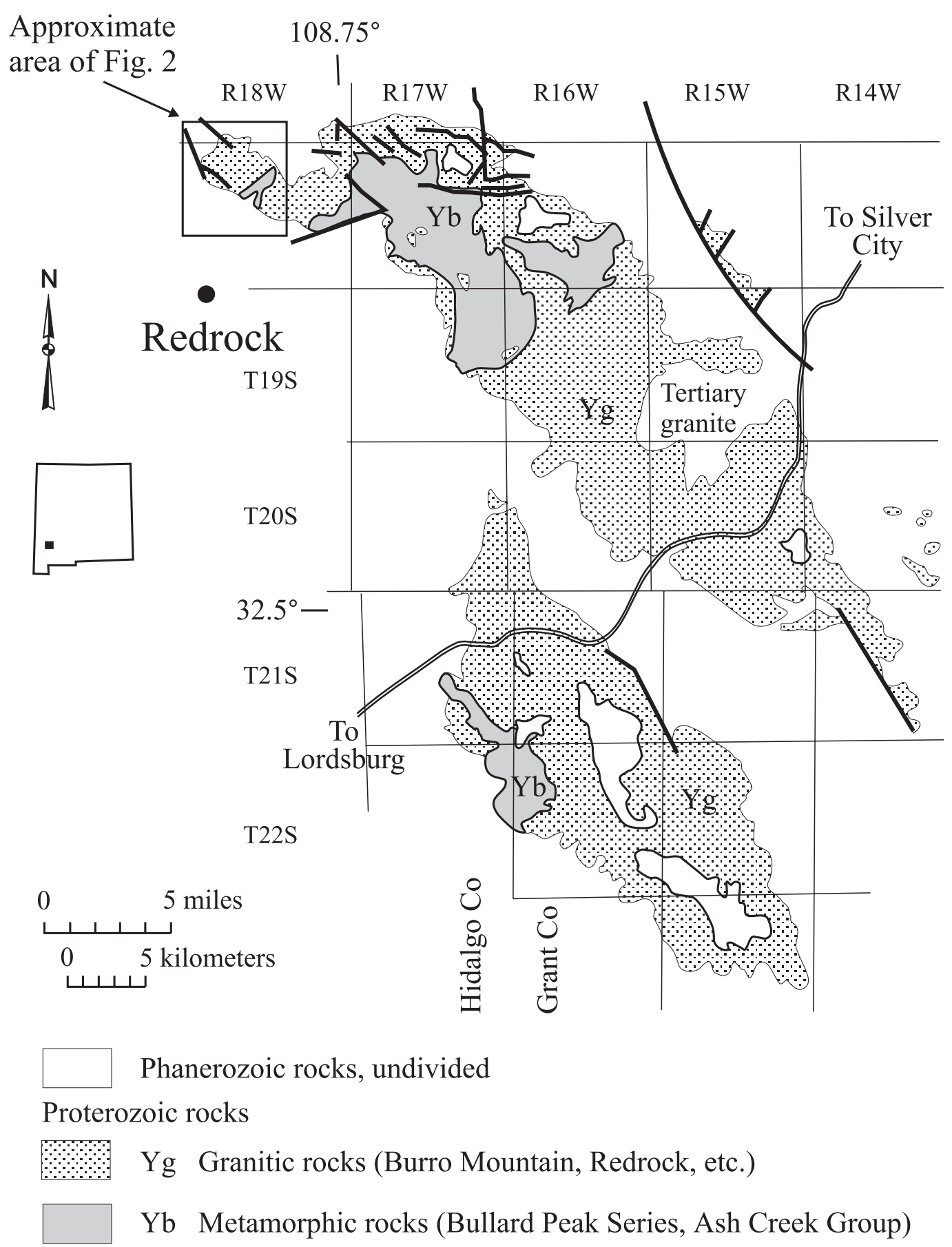

Phanerozoic rocks, undivided

Yg Granitic rocks (Burro Mountain, Redrock, etc.)

Yb Metamorphic rocks (Bullard Peak Series, Ash Creek Group)

Fig. 1. Generalized geologic map of the Proterozoic rocks in the Burro Mountains. Geology complied from Drewes et al. (1985). 
TABLE 1. Age relationships of the Proterozoic and younger rocks in the northern Burro Mountains (youngest to oldest). Best age estimates are in parenthesis (from Stacey \& Hedlund 1983, McLemore et al. 2000b, unpublished ${ }^{40} \mathrm{Ar} \mathrm{r}^{\mathrm{B}} \mathrm{Ar}$ and $\mathrm{U} / \mathrm{Pb}$ isotopic data).

\section{Units}

Tertiary rhyolite and quartz monzonite dikes and plugs

Tertiary-Cretaceous andesite sills and dikes

Cretaceous Beartooth Quartzite

Cambrian-Ordovician to Proterozoic syenite bodies

Proterozoic rocks

Gabbro/diabase/diorite dikes

Pegmatite dikes

Serpentinite veins

Fine-grained alkali feldspar and biotite granite dikes ( 1200-1220 Ma)

Rhyodacite-dacite porphyry dikes ( 1200-1220 Ma)

Redrock Granite ( 1220 Ma)

Miarolitic biotite granite/alkali feldspar granite

Hornblende granite

Biotite-hornblende granite

Anorthosite/leucogabbro xenoliths ( 1225 Ma)

Gneissic granite/granodiorite (Ygd of Hedlund 1980a, b) ( 1440-1450 Ma)

Jack Creek Rapakivi Granite ( 1465 Ma)

Porphyritic granite $(\sim 1440-1460 \mathrm{Ma})$

Minette ( 1465 Ma)

Burro Mountain Granite (Yg of Hedlund 1980a, b) ( 1440-1460 Ma)

Bullard Peak and Ash Creek metamorphic rocks (>1633, 1550-1570 Ma)

Quartzo-feldspathic gneiss (granulite of Hedlund 1980a)

Gabbro/diabase/diorite intrusions ( 1633 Ma)

rocks (Bullard Peak and Ash Creek Group, >1633, 1550-1570 Ma) that were intruded by granitic and mafic rocks (Fig. 1; Hewitt 1959, Hedlund 1980a, b, Drewes et al. 1985, McLemore \& McKee 1988a, McLemore et al. 2000b). Chemically and petrologically distinct granitic rocks in the Burro Mountains include (1) Burro Mountain Granite ( 1440-1460 Ma), (2) gneissic granite/granodiorite ( 1440-1450 Ma), (3) Jack Creek Rapakivi Granite ( 1465 Ma, McLemore et al. 2000b), (4) Redrock Granite ( 1220 Ma, McLemore et al. 2000b), (5) rhyodacite-dacite porphyry dikes, (6) fine-grained alkali feldspar and biotite granite dikes, and (7) pegmatite dikes (youngest). The mafic rocks include (1) an older group of gabbro/ diabase/diorite intrusions ( $1633 \mathrm{Ma}$; unpublished $\mathrm{U} / \mathrm{Pb}$ isotopic data), (2) several synplutonic lamprophyre (minette) dikes and numerous enclaves within the $\sim 1465$ Ma Jack Creek Rapakivi Granite, (3) approximately 50 anorthosite xenoliths (from $5 \mathrm{~m}$ in diameter to $270 \mathrm{~m}$ long and $30 \mathrm{~m}$ wide) within the Redrock Granite, and (4) a younger group of gabbro/diabase/diorite intrusions $(<1200 \mathrm{Ma})$. These age relationships are summarized in Table 1.

During the latest Proterozoic and Cambrian, the Burro Mountains were uplifted and subsequently eroded during the Paleozoic and again during the Laramide and mid-Tertiary. The Burro Mountains were either a highland during much of Phanerozoic time, or older sedimentary rocks were eroded before deposition of Cretaceous rocks when seas partially covered the mountain range. Laramide compressional tectonics and mid-Tertiary extensional tectonics have since affected the area. Andesites and rhyolites intruded some of the Proterozoic rocks during the Laramide and mid-Tertiary (Drewes et al. 1985, McLemore 2000, McLemore et al. 2000b).

The Proterozoic rocks in the Redrock area lie along the southern ring-fracture zone of the 33.5 Ma Schoolhouse Mountain caldera, which is one 
of approximately 25 calderas that formed in southwestern New Mexico during the mid-Tertiary (Wahl 1980, Finnell 1987, McIntosh et al. 1991). Younger north- and northwest-striking Basin and Range faults have offset the caldera boundary (Finnell 1987, McLemore 2000, McLemore et al. 2000b). Only the Proterozoic rocks are discussed in this report, but they have been cut and altered by these younger tectonic events.

\section{METHODS OF STUDY}

This study began in 1987, when a preliminary investigation of the Proterozoic rocks was undertaken in order to assess their economic potential (McLemore \& McKee 1988a). This early investigation also indicated that previous mapping by Hewitt (1959) and Hedlund (1980a, b) did not adequately differentiate the diverse Proterozoic rocks. Subsequent mapping by Finnell (1987) grouped the Proterozoic rocks together as one unit. Additional studies by the authors of this paper continued in 1988, 1996, and 1998-2001 and are ongoing (Kosunen et al. 1999, McLemore et al. 1999b, 2000b, Rämö et al. 1999, Haapala et al. 2000). Current studies by the authors include detailed field mapping, sampling, and analysis of the Proterozoic rocks (Fig. 2) in order to explain the petrogenesis of the mafic rocks and spatially related granites, and to assess their economic potential.

Samples of the igneous rocks were analyzed by $\mathrm{X}$-ray fluorescence spectrometry (XRF) at New Mexico Institute of Mining and Technology (NMIMT) for major and trace elements to distinguish between the various lithologic units and to determine the magmatic differentiation history. Major elements were analyzed by XRF on a Philips PW 2400 instrument using standard instrument settings on fused glass discs and trace elements using pressed powder briquettes. Instrumental neutron-activation analyses on many of the samples were carried out commercially by XRAL Laboratories (Canada). Locations of samples are shown in Appendix 1.

Polished thin-section samples were examined using a Cameca SX-100 electron microprobe at NMIMT. Samples were mapped using backscattered electrons to examine sample textures and textural relationships, before quantitative analyses of mineral phases were conducted. Instrumental conditions of $15 \mathrm{kV}$ accelerating voltage, $20 \mathrm{nA}$ beam current, and a 10-micron beam size for feldspar, 5-micron beam size for mica, and 1-micron beam size for all other phases were used. Standard ZAF recalculation procedures were used; details can be obtained from the second author. Analytical errors reported in tables are based on replicate analyses of multiple standard reference materials as defined in footnotes to the appropriate tables and appendices.

Samples were also submitted to the New Mexico Geochronological Research Laboratory at NMIMT for age determinations by ${ }^{40} \mathrm{Ar} /{ }^{39} \mathrm{Ar}$ methods; laboratory procedures are briefly described by McLemore et al. (1999a) or can be obtained from the fifth author. Representative samples have also been analyzed for $\mathrm{Nd}$ and $\mathrm{Sr}$ isotopes at the Geological Survey of Finland by the fourth author; laboratory procedures are summarized as footnotes to the appropriate tables.

\section{FIELD RELATIONSHIPS AND PETROGRAPHY}

\section{Bullard Peak and Ash Creek metamorphic rocks}

The oldest rocks in the Redrock area (Table 1, Fig. 2) are the metamorphic Bullard Peak and Ash Creek Group (Hewitt 1959) that were later correlated to each other by Hedlund (1980a, b). The metamorphic rocks were not studied in detail for this study and the reader is referred to Hewitt (1959) for more information. Since individual units are irregular in shape, discontinuous, and difficult to map, they are typically grouped as undifferentiated metamorphic rocks (Hedlund 1980a, b, Finnell 1987, McLemore et al. 2000b).

The metamorphic rocks consist of a variety of light-colored quartzo-feldspathic gneisses and schists, dark-colored biotite and hornblende schists, black amphibolite, gray to greenish-gray 

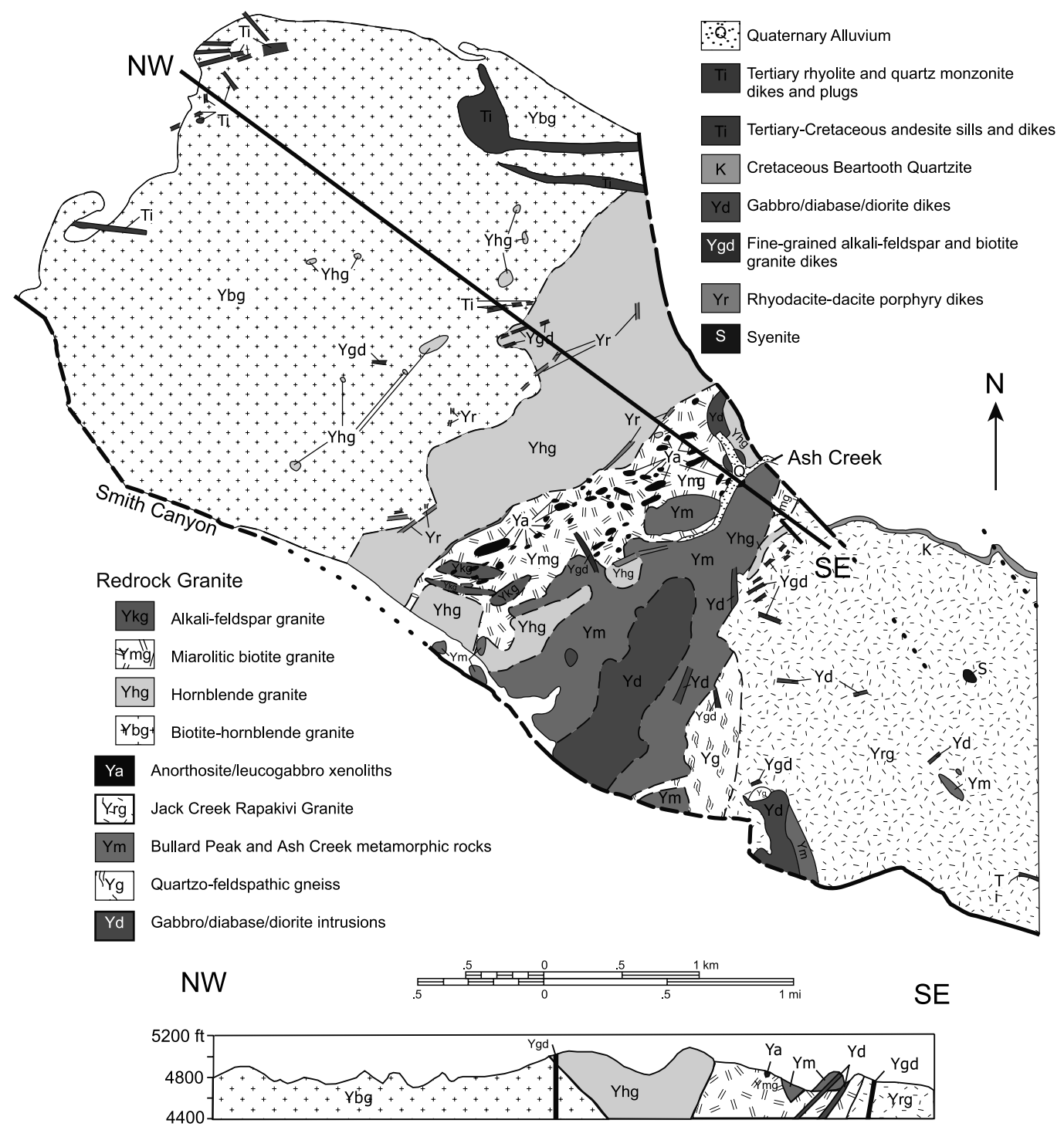

Fig. 2. Generalized geologic map of the Proterozoic rocks in the Redrock area, northern Burro Mountains (McLemore et al. 2000b, modified in part from Hewitt 1959, Hedlund 1980a, b, Finnell 1987).

phyllite, gray to white quartzite, and banded green, white, and yellow serpentine-carbonate rocks (Hewitt 1959). They consist of interlayered metaigneous and metasedimentary units that are disrupted by intrusion of granites, fine-grained alkali feldspar and biotite granite dikes, rhyodac- 
ite-dacite porphyry dikes, and pegmatites. The rocks in the Redrock area were regionally metamorphosed to the greenschist or amphibolite facies, but in Ash Creek, adjacent to the Redrock Granite, they also exhibit contact metamorphism (Hewitt 1959, McLemore et al. 2000b). Small pods of hornfels and skarn formed where the Redrock Granite intruded the serpentine-carbonate rocks. Veins of serpentine and carbonate are common within and adjacent to the intrusive contact between the Redrock Granite and the metamorphic rocks. Metamorphic foliation is well to poorly developed and variable in orientation. Migmatites are common along some contacts with the Redrock Granite. The carbonate rocks, which are older than the Redrock Granite, may correlate with the Castner Marble in the Franklin Mountains in west Texas, which has an age of $1260 \pm 20 \mathrm{Ma}(\mathrm{U} / \mathrm{Pb}$, Pittenger et al. 1994).

\section{Anorthosites}

Approximately 50 anorthosite/leucogabbro xenoliths are scattered throughout a northeast-trending zone in the miarolitic biotite granite phase of the Redrock Granite (Fig. 2). The largest body is approximately $270 \mathrm{~m}$ long and $30 \mathrm{~m}$ wide. The Redrock anorthosites are heterogeneous, altered, and commonly brecciated by diabase, gabbro, miarolitic biotite granite, and fine-grained biotite granite dikes. The anorthosites are tan to whitegray and black, medium to coarse grained with small patches of white and black leucogabbro. Euhedral relict plagioclase crystals vary in length from a few centimeters to $50 \mathrm{~cm}$ (Fig. 3).

The anorthosites have a replacement texture with relict textures suggestive of hypidiomorphicgranular to diabasic to pegmatitic (Fig. 3). They consist of unzoned, highly altered plagioclase with hornblende or pyroxene, chlorite, biotite, relict magnetite-ilmenite, and rare titanite, apatite, pyrite, olivine, and zircon. Biotite is present as subhedral to anhedral grains and is interstitial. Aggregates of biotite and hornblende with ilmenite, titanite, and other minor accessory minerals are common. Intergrowth textures of titanite, secondary chlorite, and secondary prehnite are similar to

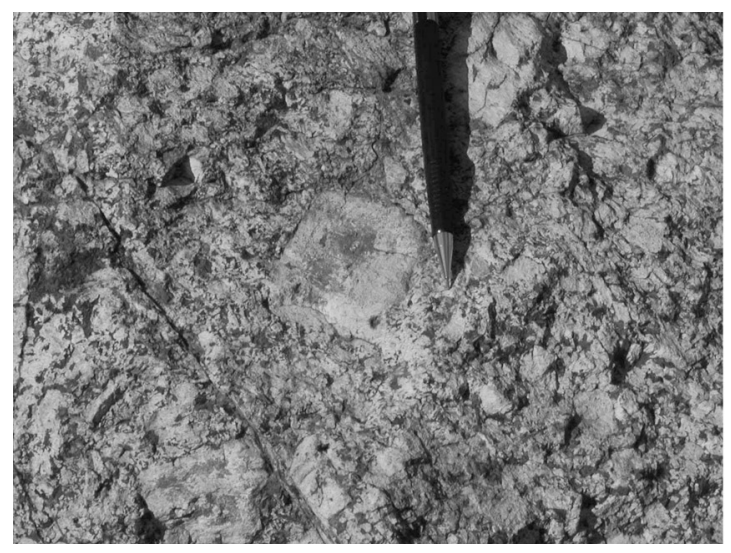

Fig. 3. An anorthosite xenolith in Ash Creek $\left(N 32.752347^{\circ}, W 108.700622^{\circ}\right)$.

contact-metasomatic textures found in skarns. Oxidized rims typically surround cubic pyrite crystals. Zircons range in size from $<10$ to $50 \mathrm{mi}$ crons and are embayed, fractured, and corroded. Alkali feldspar and quartz occur locally within the anorthosite bodies as replacements and are probably derived from fluids generated by the granitic magma. McLemore and McKee (1988a) described a quartz anorthosite and a hybrid anorthosite, which is consistent with the replacement. Fine-grained biotite granite dikes brecciate some of the anorthosites. The anorthosites locally exhibit replacement of plagioclase by as many as three feldspar compositions (described in mineral chemistry section below). These relationships are consistent with the anorthosite xenoliths being partially metamorphosed and/or hydrothermally altered by the Redrock Granite.

Anorthosites are commonly classified into six groups based on age, texture, tectonic setting, and associations of other mafic rocks (Ashwal \& Burke 1987, Ashwal 1993, Easton 1990): (1) Archean megacrystic anorthosites, (2) massif-type anorthosites, (3) anorthosites of layered mafic intrusions, (4) anorthosites of oceanic settings, (5) anorthosite inclusions, and (6) other types. It is difficult to classify the Redrock anorthosites with confidence because they are altered xenoliths within the Redrock Granite. However, it appears that the Redrock anorthosites are best classified 
as massif-type on the basis of relict textures (coarse, lath-shaped plagioclase phenocrysts), intermediate plagioclase composition (see mineral chemistry section below), general tectonic setting (probably continental, possibly extensional), and age (probably 1400-1200 Ma). Type 3, anorthosites of layered mafic intrusions, cannot be eliminated as a classification of the Redrock anorthosite xenoliths with available data.

\section{Redrock Granite}

The Redrock Granite forms the western margin of the Proterozoic terrain north of Redrock (Fig. 1). It extends from Smith Canyon southeastward to Ash Creek (Fig. 2). Four phases of granite are mapped: hornblende granite, biotite-hornblende granite, miarolitic biotite granite, and alkali feldspar granite. These granites are texturally and mineralogically distinct, but they have chemical compositions that imply them to be genetically related. Xenoliths of metamorphic rocks are locally common in the hornblende granite, biotite-hornblende granite, and miarolitic biotite granite phases. Hedlund (1980a) originally designated this granite and the Jack Creek Rapakivi Granite as the granite of Redrock. McLemore et al. (2000b) redefined the Redrock Granite as the granitic rocks that crop out west and north of Ash Creek (Fig. 2 ), on the basis of textural, mineralogical, and chemical differences between the Redrock Granite and the Jack Creek Rapakivi Granite farther to the east. Small exposures of the Redrock Granite are found south of Ash Creek. The four types of granite are described in order of perceived age (oldest to youngest).

\section{Biotite-hornblende granite}

The medium- to coarse-grained biotite-hornblende granite is orange to red-brown and consists of plagioclase, alkali feldspar, quartz, biotite, hornblende, and trace amounts of zircon, titanite, ilmenite, and apatite. This granite weathers to dark orange-brown knobby outcrops. Epidote alteration is common. The biotite-hornblende granite grades into the hornblende granite. Xenoliths are rare.
The granite is unconformably overlain by Tertiary ash-flow tuff along the western and northern contacts where it is highly weathered and altered (Fig. 2).

Both plagioclase and alkali feldspar occur as euhedral to lath-shaped crystals. Alkali feldspar shows exsolution. Some portions of the granite are alkali feldspar rich, whereas other portions are albite rich. Albite is zoned, typically with a sodium-rich core. Biotite is present as subhedral to anhedral grains, is interstitial, and appears to have crystallized last. Aggregates of biotite and hornblende with ilmenite and other minor accessory minerals are common. Zircons are rounded and interstitial.

\section{Hornblende granite}

The coarse-grained hornblende granite is orange to red-brown and consists of plagioclase, alkali feldspar, quartz, hornblende, and trace amounts of zircon, titanite, ilmenite, and apatite; biotite concentrations vary from none to trace amounts. This granite weathers to dark orange-brown knobby outcrops and is slightly foliated; the foliation is formed by dark hornblende phenocrysts up to 2 $\mathrm{cm}$ long (Fig. 4). Xenoliths and pegmatites are rare.

Both plagioclase and alkali feldspar occur as euhedral to lath-shaped crystals. Alkali feldspar shows exsolution. Albite is zoned, typically with a sodium-rich core. Interstitial biotite, where present, occurs as subhedral to anhedral grains. Aggregates of biotite and hornblende with ilmenite and other minor accessory minerals are common. Zircons are rounded and interstitial.

Field relationships indicate that the hornblende granite is younger than the Jack Creek Rapakivi Granite. At the sharp intrusive contact between the hornblende granite and the Jack Creek Rapakivi Granite east of Ash Creek, the hornblende granite is medium grained and increases in grain size away from the contact (i.e. a chilled margin; Fig. 5). The rapakivi granite is slightly foliated near the contact and plagioclase phenocrysts within the rapakivi granite are cut by the Redrock Granite. Pegmatite and fine-grained biotite granite dikes, 

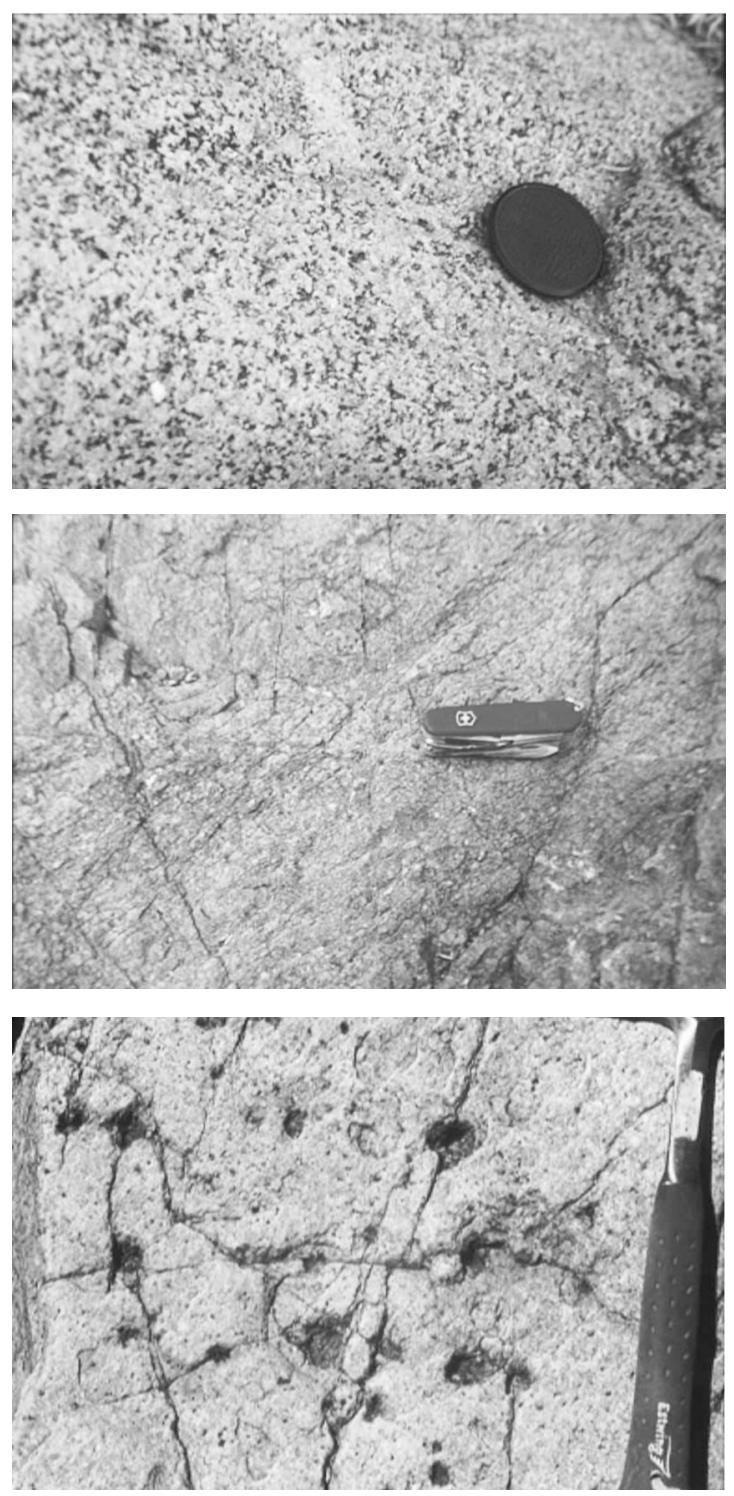

probably related to the Redrock Granite, intruded the rapakivi granite parallel to the contact.

\section{Miarolitic biotite granite}

The miarolitic biotite granite is orange to pink, fine- to medium-grained, and consists of plagioclase, alkali feldspar, quartz, biotite, muscovite, and trace amounts of hornblende, zircon, titanite, magnetite, ilmenite, monazite, andradite garnet, fluor-
Fig. 4. The hornblende granite phase of the Redrock Granite $\left(N 32.74833^{\circ}\right.$, W108.7217 $)$.

Fig. 5. Contact between the Redrock Granite (the hornblende granite phase, upper half of the figure) and the Jack Creek Rapakivi Granite (N32.748479 ${ }^{\circ}$, W108.698118).

Fig. 6. Miarolitic cavities in the miarolitic biotite granite phase of the Redrock Granite (N32.753072 ${ }^{\circ}$, $\left.W 108.702676^{\circ}\right)$.

ite, and apatite. It is characterized by miarolitic cavities that are nearly circular to elliptical in shape and range from $<1 \mathrm{~cm}$ to $15 \mathrm{~cm}$ in diameter (Fig. 6). Metamorphic and anorthosite/leucogabbro xenoliths are common in the miarolitic biotite granite.

Both plagioclase and alkali feldspar occur as euhedral to lath-shaped crystals. Alkali feldspar shows exsolution. Biotite is present as subhedral to anhedral grains, is interstitial, and appears to 
have crystallized last. Aggregates of biotite, muscovite, and hornblende with ilmenite and other minor accessory minerals are common. Euhedral grains of monazite form inclusions within quartz phenocrysts. Titanite occurs as euhedral crystals or irregular masses. Zircons are rounded and interstitial.

Two types of muscovite are observed in the miarolitic biotite granite. The first are large, subhedral to euhedral crystals, and the second are smaller patches and intergrowths of muscovite and biotite. The first type of muscovite appears to be magmatic on the basis of texture using the criteria of Barbarin (1996) and Roycroft (1991). The magmatic muscovite is well crystallized with clean crystal terminations, is of similar size and shape as other magmatic crystals, and contains small accessory minerals along crystal faces. The magmatic muscovites are not enclosed by or do not enclose any potassium-bearing minerals from which the muscovite could be an alteration product. The difference in mineral chemistry (see mineral chemistry section below) and textures of other muscovites, which are finely intergrown with biotite, suggest that the second type formed by a local subsolidus alteration within the granite (see Barbarin 1996). The altered muscovites are anhedral to subhedral, embayed, fractured, and occur in the vicinity or surrounding alkali feldspar and biotite.

Along the contact between the miarolitic biotite granite and hornblende granite, small dikes of younger biotite granite and rhyodacite-dacite porphyry intruded the hornblende granite. In places, the miarolitic biotite granite has brecciated a xenolith or roof pendant of the hornblende granite, which indicates that the miarolitic biotite granite is the younger phase (Table 1). Elsewhere the contact is sharp or covered.

Locally, the miarolitic biotite granite is pervasively altered to epidote, quartz, and chlorite along fractures and in thin veins. Altered zones and veins are as much as $2 \mathrm{~m}$ wide and are controlled by fractures. The magmatic-hydrothermal alteration has formed greenish-gray aggregates or balls of epidote, quartz, hematite, and chlorite within miarolitic cavities up to $20 \mathrm{~cm}$ in diameter (Fig. 6).
Some of these epidote balls occur alone within the granite surrounded by relatively unaltered granite, whereas other areas exhibit vertical trains or linear arrays of these balls connected by fractures containing epidote, quartz, and chlorite. Here and there, large $(<6 \mathrm{~cm}$ long) alkali feldspar phenocrysts form a halo surrounding the epidote balls. Hematite is locally abundant in the veins and cavities. This alteration is typical of degassing of the underlying pluton and resembles in appearance and mode of occurrence greisen or tourmaline alteration of granite elsewhere in the world (e.g. Richardson et al. 1990), but with different mineralogy and chemical composition (Haapala et al. 2000).

\section{Alkali feldspar granite}

Small lenses of white to light pinkish-gray, finegrained alkali feldspar granite are intermingled with the miarolitic biotite granite. This granite differs from the miarolitic biotite granite by a lighter color, fewer miarolitic cavities, and absence of biotite and xenoliths. It contains alkali feldspar, quartz, and varying amounts of plagioclase. Both plagioclase and alkali feldspar occur as euhedral to lath-shaped crystals. The contacts with the miarolitic biotite granite are gradational. The alkali feldspar granite is most likely a differentiate of the miarolitic biotite granite.

\section{Fine-grained alkali feldspar and biotite granite dikes}

White to gray, fine-grained alkali feldspar granite dikes and orange-pink to gray-pink, finegrained biotite granite dikes intruded the Redrock, Jack Creek Rapakivi, and Burro Mountain granites and some of the larger gabbro/diabase/diorite intrusions (Fig. 2). The intrusive contacts are sharp and locally chilled along the dike margins. The dikes vary in size up to several meters wide and $100 \mathrm{~m}$ long and consist of plagioclase, alkali feldspar, quartz, biotite or muscovite, and trace amounts of zircon, titanite, ilmenite, and apatite. The dikes have no preferred orientation. 
TABLE 2. Representative alkali feldspar analyses of the Redrock Granite and the anorthosites.

\begin{tabular}{|c|c|c|c|c|c|c|c|c|c|c|}
\hline & \multicolumn{3}{|c|}{$\begin{array}{l}\text { Redrock } \\
\text { miarolitic biotite granite }\end{array}$} & \multicolumn{2}{|c|}{$\begin{array}{l}\text { Redrock biotite- } \\
\text { hornblende granite }\end{array}$} & \multicolumn{2}{|c|}{$\begin{array}{l}\text { Redrock } \\
\text { hornblende granite }\end{array}$} & \multicolumn{3}{|c|}{ Anorthosite } \\
\hline & $\begin{array}{l}\text { NM } \\
11-14 \\
\end{array}$ & $\begin{array}{l}\text { NM } \\
11-19 \\
\end{array}$ & $\begin{array}{l}\text { NM93- } \\
98-17\end{array}$ & $\begin{array}{l}\text { NM93- } \\
98-18\end{array}$ & $\begin{array}{l}\text { NM279- } \\
99-8\end{array}$ & $\begin{array}{l}\text { NM } \\
19-48 \\
\end{array}$ & $\begin{array}{l}\text { NM } \\
131-12 \\
\end{array}$ & $\begin{array}{l}\text { NM } \\
131-40 \\
\end{array}$ & $\begin{array}{l}\text { NM } \\
1-6 \\
\end{array}$ & $\begin{array}{l}\text { NM } \\
312-35 \\
\end{array}$ \\
\hline $\mathrm{SiO}_{2}$ & 64.19 & 64.37 & 63.65 & 64.21 & 64.78 & 64.35 & 64.44 & 63.83 & 63.28 & 63.70 \\
\hline $\mathrm{Al}_{2} \mathrm{O}_{3}$ & 18.83 & 18.89 & 19.02 & 19.06 & 18.97 & 18.44 & 18.81 & 18.75 & 18.55 & 18.86 \\
\hline $\mathrm{CaO}$ & 0.00 & 0.02 & 0.05 & 0.09 & 0.03 & 0.02 & 0.00 & 0.04 & 0.08 & 0.02 \\
\hline $\mathrm{FeO}$ & 0.08 & 0.00 & 0.11 & 0.04 & 0.12 & 0.20 & 0.04 & 0.09 & 0.98 & 0.06 \\
\hline $\mathrm{SrO}$ & n.d. & n.d. & n.d. & n.d. & n.d. & n.d. & n.d. & n.d. & n.d. & n.d. \\
\hline $\mathrm{BaO}$ & n.d. & n.d. & 0.41 & 0.24 & 0.18 & 0.27 & 0.16 & 0.26 & 0.33 & 0.26 \\
\hline $\mathrm{Na}_{2} \mathrm{O}$ & 0.30 & 0.04 & 0.33 & 0.76 & 1.56 & 0.29 & 1.55 & 0.82 & 0.32 & 0.31 \\
\hline $\mathrm{K}_{2} \mathrm{O}$ & 16.72 & 16.87 & 16.55 & 16.01 & 15.13 & 16.24 & 15.09 & 15.90 & 16.34 & 16.64 \\
\hline Total & 100.18 & 100.21 & 100.12 & 100.44 & 100.78 & 99.84 & 100.09 & 99.69 & 99.89 & 99.90 \\
\hline $\mathrm{Ab}$ & 2.6 & 0.3 & 2.9 & 6.7 & 13.5 & 2.6 & 13.5 & 7.3 & 2.9 & 2.8 \\
\hline An & 0 & 0.1 & 0.3 & 0.4 & 0.1 & 0.1 & 0 & 0.2 & 0.4 & 0.1 \\
\hline Or & 97.4 & 99.6 & 96.8 & 92.9 & 86.4 & 97.3 & 86.5 & 92.5 & 96.7 & 97.1 \\
\hline
\end{tabular}

Analytical error, based on 12 replicate analyses of standard reference materials MAD-10 orthoclase (UCB 374 used for $\mathrm{SiO}_{2}, \mathrm{Al}_{2} \mathrm{O}_{3}$, and $\mathrm{FeO}$ ), Cazadero albite (UCB 301, used for $\mathrm{Na}_{2} \mathrm{O}$ ) and Grass Valley anorthite (UCB 305, used for CaO) (all obtained from University of California at Berkeley), from 2 separate analytical sessions, are as follows: $\mathrm{SiO}_{2} \pm 0.4$ wt. $\%, \mathrm{Al}_{2} \mathrm{O}_{3} \pm 0.1$ wt. $\%, \mathrm{CaO} \pm 0.2$ wt. $\%, \mathrm{FeO} \pm 0.03$ wt. $\%, \mathrm{Na}_{2} \mathrm{O} \pm 0.08$ wt. $\%$, and $\mathrm{K}_{2} \mathrm{O} \pm 0.18$ wt. $\%$. The levels of Ba and $\mathrm{Sr}$ in the reference materials are not sufficient to determine analytical error, but the detection limits for these two elements are 0.07 and 0.06 wt.\%, respectively.

\section{Pegmatites}

Pegmatites are relatively rare in the Redrock area as compared to other Proterozoic terranes in New Mexico. They are mostly simple pegmatites, consisting of quartz, plagioclase, alkali feldspar, and muscovite with rare biotite. They are pink-red and typically small, from a few centimeters to $<1 \mathrm{~m}$ wide and several tens of meters long. In places, quartz forms an irregular core surrounded by intergrown plagioclase, alkali feldspar, and locally muscovite. Pegmatites occur predominantly in the miarolitic biotite granite, but are found intruding all the granitic rocks. Tourmaline and ilmenite are found in a few dikes that intruded the miarolitic biotite granite phase of the Redrock Granite.

\section{MINERAL CHEMISTRY}

Quantitative chemical analyses were performed on feldspars, amphiboles, and micas from the biotitehornblende, hornblende, and miarolitic biotite phases of the Redrock Granite using the electron microprobe (Appendices 2-5). Backscattered electron (BSE) imagery was used to study the appearance of the mineral phases, as well as to select the locations of analyzed points, so the textural context of each analysis is well understood. Quantitative chemical analyses were performed on feldspars and amphiboles of the anorthosites.

\section{Feldspars}

A total of 234 points were analyzed to determine the compositions of feldspars (Tables 2, 3, Fig. 7, Appendices 2, 3). The feldspars in the anorthosite samples appear to preserve no primary igneous textures, but are patchy and show evidence of extensive chemical alteration. The compositions of these feldspars are not interpreted to represent original igneous compositions. The least-altered plagioclase found in the anorthosites is labradorite $\left(\mathrm{An}_{53}\right.$ to $\left.\mathrm{An}_{59}\right)$; albite to oligoclase (of secondary alteration) is also present (Table 3, Fig. 7, Appen$\operatorname{dix} 3$ ). Orthoclase (related to secondary alteration) is also found in the anorthosites. 
TABLE 3. Representative plagioclase analyses of the Redrock Granite and the anorthosites.

Redrock miarolitic Redrock biotite- Redrock hornblende granite

Anorthosites biotite granite hornblende granite

\begin{tabular}{|c|c|c|c|c|c|c|c|c|c|c|c|c|}
\hline & $\begin{array}{l}\mathrm{NM} \\
11-16\end{array}$ & $\begin{array}{l}\mathrm{NM} \\
11-21\end{array}$ & $\begin{array}{l}\text { NM93- } \\
98-4\end{array}$ & $\begin{array}{l}\text { NM279- } \\
99-3\end{array}$ & $\begin{array}{l}\text { NM } \\
19-55\end{array}$ & $\begin{array}{l}\mathrm{NM} \\
131-4\end{array}$ & $\begin{array}{l}\text { NM } \\
1-22\end{array}$ & $\begin{array}{l}\text { Red } \\
7-6\end{array}$ & $\begin{array}{l}\text { Red } \\
7-8\end{array}$ & $\begin{array}{l}\text { NM } \\
312-11\end{array}$ & $\begin{array}{l}\text { Red } \\
4-6\end{array}$ & $\begin{array}{l}\text { Red } \\
4-19\end{array}$ \\
\hline $\mathrm{SiO}_{2}$ & 66.51 & 64.18 & 64.57 & 67.18 & 66.45 & 63.06 & 66.89 & 52.74 & 62.34 & 67.31 & 55.74 & 53.06 \\
\hline $\mathrm{Al}_{2} \mathrm{O}_{3}$ & 21.20 & 22.83 & 22.69 & 21.01 & 21.10 & 23.48 & 20.94 & 29.99 & 23.75 & 20.34 & 31.61 & 30.03 \\
\hline $\mathrm{CaO}$ & 1.55 & 3.24 & 2.23 & 0.31 & 1.37 & 4.18 & 0.46 & 12.00 & 3.97 & 1.25 & 2.37 & 11.79 \\
\hline $\mathrm{FeO}$ & 0.01 & 0.06 & 0.15 & 0.09 & 0.19 & 0.08 & 0.15 & 0.23 & 0.07 & 0.24 & 0.15 & 0.66 \\
\hline $\mathrm{SrO}$ & n.d. & n.d. & 0.08 & n.d. & n.d. & n.d. & n.d. & n.d. & n.d. & n.d. & 0.20 & 0.08 \\
\hline $\mathrm{BaO}$ & n.d. & n.d. & 0.11 & n.d. & n.d. & n.d. & n.d. & n.d. & n.d. & 0.06 & n.d. & n.d. \\
\hline $\mathrm{Na}_{2} \mathrm{O}$ & 10.90 & 9.76 & 9.67 & 11.05 & 10.80 & 9.22 & 10.93 & 4.45 & 8.96 & 11.22 & 7.82 & 4.57 \\
\hline $\mathrm{K}_{2} \mathrm{O}$ & 0.08 & 0.38 & 0.82 & 0.63 & 0.22 & 0.20 & 0.51 & 0.32 & 0.39 & 0.04 & 1.06 & 0.39 \\
\hline Total & 100.26 & 100.47 & 100.31 & 100.28 & 100.15 & 100.25 & 99.93 & 99.76 & 99.54 & 100.51 & 99.00 & 100.60 \\
\hline $\mathrm{Ab}$ & 92.30 & 82.70 & 84.50 & 95.00 & 92.30 & 79.10 & 94.90 & 39.40 & 78.50 & 94.00 & 79.60 & 40.30 \\
\hline An & 7.30 & 15.20 & 10.80 & 1.50 & 6.50 & 19.80 & 2.20 & 58.70 & 19.20 & 5.80 & 13.30 & 57.50 \\
\hline Or & 0.40 & 2.10 & 4.70 & 3.60 & 1.20 & 1.10 & 2.90 & 1.90 & 2.20 & 0.20 & 7.10 & 2.30 \\
\hline
\end{tabular}

Analytical error, based on 12 replicate analyses of standard reference materials MAD-10 orthoclase (UCB 374 used for $\mathrm{SiO}_{2}, \mathrm{Al}_{2} \mathrm{O}_{3}$, and $\mathrm{FeO}$ ), Cazadero albite (UCB 301, used for $\mathrm{Na}_{2} \mathrm{O}$ ) and Grass Valley anorthite (UCB 305, used for CaO) (all obtained from University of California at Berkeley), from 2 separate analytical sessions, are as follows: $\mathrm{SiO}_{2} \pm 0.4$ wt. $\%, \mathrm{Al}_{2} \mathrm{O}_{3} \pm 0.1$ wt. $\%, \mathrm{CaO} \pm 0.2$ wt. $\%, \mathrm{FeO} \pm 0.03$ wt. $\%, \mathrm{Na}_{2} \mathrm{O} \pm 0.08$ wt. $\%$, and $\mathrm{K}_{2} \mathrm{O} \pm 0.18$ wt. $\%$. The levels of $\mathrm{Ba}$ and $\mathrm{Sr}$ in the reference materials are not sufficient to determine analytical error, but the detection limits for these two elements are 0.07 and $0.06 \mathrm{wt} . \%$, respectively.

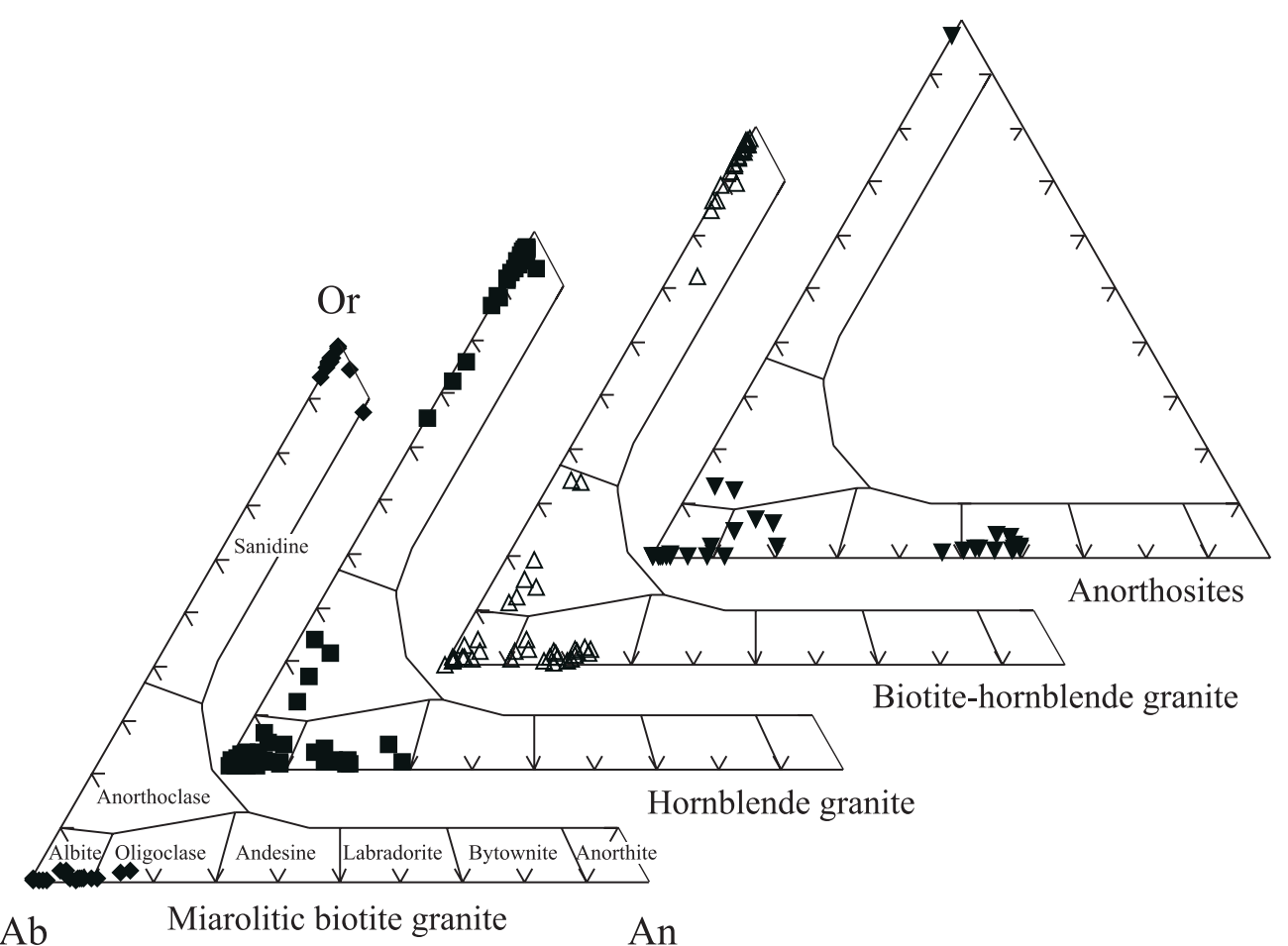

Fig. 7. Composition of feldspars of the Redrock Granite and the anorthosites. Analytical errors are found in Tables 2 and 3 . 
The biotite-hornblende, hornblende, and miarolitic biotite phases of the Redrock Granite all contain two primary feldspars: potassic alkali feldspar and sodic plagioclase. Both feldspars exhibit primary igneous textures, and the alkali feldspar shows extensive perthitization. Some crystals of the plagioclase are compositionally zoned, with slightly more potassium and less sodium in the crystal rims relative to the cores. The alkali feldspar is orthoclase, between $\mathrm{Or}_{86}$ and $\mathrm{Or}_{98}$ (Table 2, Fig. 7, Appendix 2); composition of the plagioclase ranges from $\mathrm{An}_{0}$ to $\mathrm{An}_{28}$ (albite to oligoclase) (Table 3, Fig. 7, Appendix 3). Many of the feldspar analyses are from areas of perthitization, and are not truly representative of the original igneous feldspar compositions, but rather represent the two unmixed feldspar endmembers. The perthitic lamellae are typically pure albite endmember, whereas the larger crystals of albitic feldspar in the granite contain more calcium. Some analyses of feldspar fall in the anorthoclase compositional field (Fig. 7). These are interpreted to represent unintentional overlap of the electron beam onto finely exsolved endmembers. However, because exsolution at this fine scale could not be directly observed using BSE imaging, there is no justification for discarding these data.

\section{Amphiboles}

Amphiboles are found in the biotite-hornblende granite, the hornblende granite, and in one of the anorthosite samples. A total of 53 points were analyzed (Table 4, Appendix 4). The composition of amphiboles shows a range, particularly with respect to $\mathrm{FeO}$ and $\mathrm{MgO}$, but all samples appear to be part of a geochemical trend (Fig. 8). Amphibole compositions from the two granite phases overlap, and range from ferro-actinolite to ferro-edenite or hastingsitic hornblende and are ironrich with $\mathrm{Fe} /(\mathrm{Fe}+\mathrm{Mg})$ ranging from 0.7 to 1.0 (Table 4). Mafic silicates with high $\mathrm{Fe} /(\mathrm{Fe}+\mathrm{Mg})$ are characteristic of subalkaline A-type granites, including many of the Proterozoic rapakivi granites (Rämö \& Haapala 1995, Elliott 2001) and the Red Bluff Granite in west Texas (Shannon et al. 1997).

TABLE 4. Representative amphibole analyses of the Redrock Granite and the anorthosites.

\begin{tabular}{|c|c|c|c|c|c|c|c|}
\hline & \multicolumn{2}{|c|}{$\begin{array}{l}\text { Redrock biotite- } \\
\text { hornblende granite }\end{array}$} & \multicolumn{4}{|c|}{ Redrock hornblende granite } & \multirow{2}{*}{$\begin{array}{l}\text { Anorthosite } \\
\text { NM } \\
312-38\end{array}$} \\
\hline & $\begin{array}{l}\text { NM93- } \\
98-35\end{array}$ & $\begin{array}{l}\text { NM279- } \\
99-37\end{array}$ & $\begin{array}{l}\text { NM } \\
1-27\end{array}$ & $\begin{array}{l}\text { NM } \\
1-48\end{array}$ & $\begin{array}{l}\text { NM } \\
19-66 \\
\end{array}$ & $\begin{array}{l}\text { NM } \\
131-23\end{array}$ & \\
\hline $\mathrm{SiO}_{2}$ & 40.61 & 39.33 & 41.70 & 39.15 & 49.32 & 38.05 & 45.91 \\
\hline $\mathrm{TiO}_{2}$ & 1.32 & 1.59 & 0.14 & 1.79 & 0.69 & 1.39 & 1.16 \\
\hline $\mathrm{Al}_{2} \mathrm{O}_{3}$ & 8.27 & 7.94 & 6.96 & 8.69 & 3.27 & 8.32 & 6.56 \\
\hline $\mathrm{MgO}$ & 3.02 & 2.26 & 0.78 & 0.72 & 10.21 & 2.09 & 8.89 \\
\hline $\mathrm{CaO}$ & 10.09 & 9.67 & 11.00 & 10.15 & 11.17 & 9.54 & 10.89 \\
\hline $\mathrm{MnO}$ & 0.81 & 0.57 & 0.43 & 0.72 & 0.42 & 1.05 & 0.40 \\
\hline $\mathrm{FeO}$ & 30.13 & 31.50 & 34.33 & 33.42 & 21.14 & 31.58 & 22.42 \\
\hline $\mathrm{Na}_{2} \mathrm{O}$ & 1.77 & 1.99 & 1.03 & 1.99 & 1.30 & 1.57 & 0.91 \\
\hline $\mathrm{K}_{2} \mathrm{O}$ & 1.21 & 1.35 & 1.32 & 1.24 & 0.44 & 1.30 & 0.59 \\
\hline $\mathrm{H}_{2} \mathrm{O}$ & 1.63 & 1.55 & 1.77 & 1.67 & 1.67 & 0.03 & 1.84 \\
\hline $\mathrm{F}$ & 0.45 & 0.54 & 0.11 & 0.33 & 0.66 & 3.67 & 0.27 \\
\hline Total & 99.30 & 98.27 & 99.57 & 99.86 & 100.29 & 98.59 & 99.82 \\
\hline $\mathrm{Fe}$ & 23.36 & 24.42 & 26.61 & 25.91 & 16.39 & 24.48 & 17.38 \\
\hline $\mathrm{Mg}$ & 1.82 & 1.36 & 0.47 & 0.44 & 6.16 & 1.26 & 5.36 \\
\hline $\mathrm{Fe} /(\mathrm{Fe}+\mathrm{Mg})$ & 0.93 & 0.95 & 0.98 & 0.98 & 0.73 & 0.95 & 0.76 \\
\hline
\end{tabular}

Analytical error, based on 12 replicate analyses of standard reference material Kakanui hornblende (obtained from the Smithsonian Institution), from 2 separate analytical sessions, are as follows: $\mathrm{SiO}_{2} \pm 0.29$ wt. $\%, \mathrm{TiO}_{2} \pm 0.1 \mathrm{wt}$. $\%, \mathrm{Al}_{2} \mathrm{O}_{3}$ \pm 0.08 wt. $\%, \mathrm{MgO} \pm 0.12$ wt. $\%, \mathrm{CaO} \pm 0.11$ wt. $\%, \mathrm{MnO} \pm 0.01$ wt. $\%, \mathrm{FeO} \pm 0.13$ wt. $\%, \mathrm{Na}_{2} \mathrm{O} \pm 0.13$ wt. $\%, \mathrm{~K}_{2} \mathrm{O} \pm 0.05$ wt. $\%$, and $\mathrm{F} \pm 0.04$ wt. $\%$. 

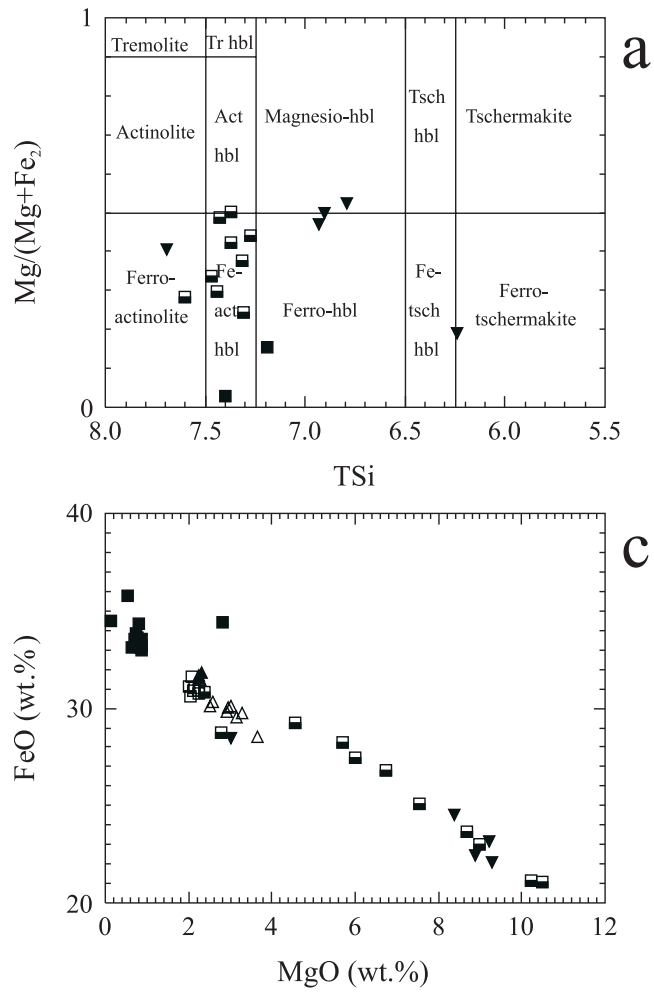
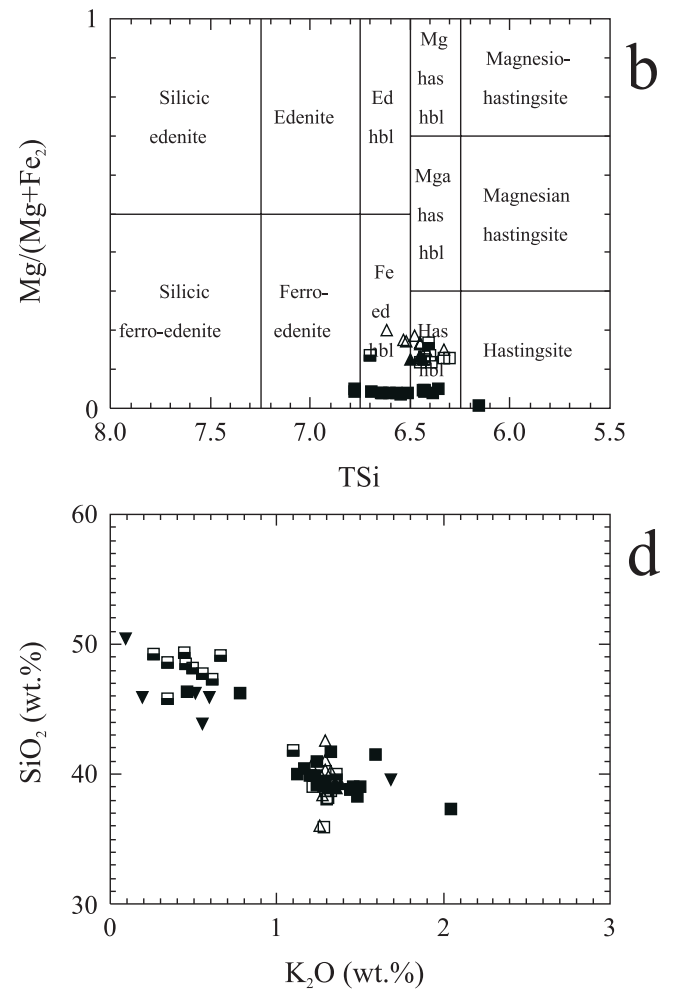

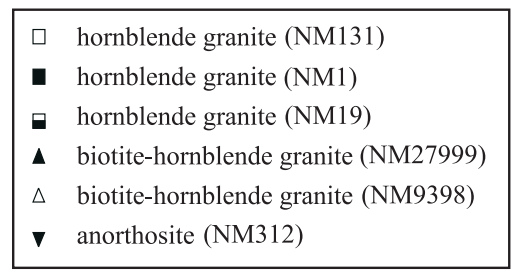

Fig. 8. Composition of amphiboles of the Redrock Granite and the anorthosites. $\mathrm{Mg} /\left(\mathrm{Mg}+\mathrm{Fe}_{2}\right) v \mathrm{v}$. TSi, following the classification of Leake (1978) and Leake et al. (1997), is shown in (a) and (b); (c) and (d) represent electron-microprobe-determined compositions of individual amphibole crystals. Analytical errors are found in Table 4, and are generally smaller than the symbol size.

Amphiboles from two samples of the biotite-hornblende granite (NM27999 and NM9398) and one sample of the hornblende granite (NM131) define tight groups and are compositionally indistinguishable (Fig. 8). Amphiboles from a second sample of the hornblende granite (NM1) also define a tight compositional group, but contain slightly more Fe and less $\mathrm{Mg}$ than the amphiboles from the previously mentioned samples, although the $\mathrm{CaO}, \mathrm{K}_{2} \mathrm{O}, \mathrm{SiO}_{2}, \mathrm{Al}_{2} \mathrm{O}_{3}$, and $\mathrm{Na}_{2} \mathrm{O}$ are indistin- guishable (Fig. 8, Table 4). This hornblende granite sample is less evolved than the other samples in terms of major element composition (discussed later), and the small discrepancy between the amphibole of this sample and others is likely to be due to the more primitive nature of the melt from which these crystals formed. The consistency of amphibole chemical composition from the samples of the hornblende granite and the biotite-hornblende granite suggests that the magmas were geo- 
TABLE 5. Representative mica analyses of the Redrock Granite

\begin{tabular}{|c|c|c|c|c|c|c|c|c|c|}
\hline & \multicolumn{5}{|c|}{ Redrock miarolitic biotite granite } & \multicolumn{2}{|c|}{$\begin{array}{l}\text { Redrock } \\
\text { hornblende granite }\end{array}$} & \multicolumn{2}{|c|}{$\begin{array}{l}\text { Redrock biotite- } \\
\text { hornblende granite }\end{array}$} \\
\hline & $\begin{array}{l}\text { NM } \\
11-13 \\
\end{array}$ & $\begin{array}{l}\text { NM } \\
11-12 \\
\end{array}$ & $\begin{array}{l}\text { NM } \\
11-7 \\
\end{array}$ & $\begin{array}{l}\text { NM } \\
11-n 7 \\
\end{array}$ & $\begin{array}{l}\text { NM } \\
11-n 10\end{array}$ & $\begin{array}{l}\text { NM } \\
131-17\end{array}$ & $\begin{array}{l}\text { NM } \\
131-44\end{array}$ & $\begin{array}{l}\text { NM93- } \\
98-24\end{array}$ & $\begin{array}{l}\text { NM93- } \\
98-26\end{array}$ \\
\hline $\mathrm{SiO}_{2}$ & 45.74 & 50.31 & 47.06 & 48.15 & 43.20 & 34.21 & 34.03 & 34.08 & 33.22 \\
\hline $\mathrm{TiO}_{2}$ & 0.03 & 0.06 & 0.32 & 0.08 & 0.16 & 4.04 & 3.94 & 3.69 & 3.51 \\
\hline $\mathrm{Al}_{2} \mathrm{O}_{3}$ & 37.85 & 28.69 & 28.82 & 25.08 & 22.68 & 12.41 & 12.29 & 12.48 & 12.73 \\
\hline $\mathrm{Cr}_{2} \mathrm{O}_{3}$ & 0.03 & 0.03 & 0.04 & 0.00 & 0.01 & 0.00 & 0.01 & 0.05 & 0.00 \\
\hline $\mathrm{MgO}$ & 0.00 & 1.26 & 0.00 & 1.98 & 1.93 & 2.73 & 2.93 & 4.12 & 5.00 \\
\hline $\mathrm{CaO}$ & 0.01 & 0.14 & 0.03 & 0.38 & 0.40 & 0.08 & 0.00 & 0.10 & 0.17 \\
\hline $\mathrm{MnO}$ & 0.40 & 0.01 & 0.32 & 0.34 & 0.37 & 0.49 & 0.55 & 0.37 & 0.38 \\
\hline $\mathrm{FeO}$ & 0.62 & 5.20 & 6.70 & 10.93 & 17.94 & 32.66 & 32.47 & 31.42 & 32.59 \\
\hline $\mathrm{BaO}$ & n.d & n.d & n.d & n.d & n.d & n.d & n.d & n.d & n.d \\
\hline $\mathrm{Na}_{2} \mathrm{O}$ & 0.24 & 0.13 & 0.13 & 0.46 & 0.43 & 0.10 & 0.05 & 0.10 & 0.16 \\
\hline $\mathrm{K}_{2} \mathrm{O}$ & 10.43 & 9.45 & 11.06 & 7.50 & 6.51 & 8.95 & 9.21 & 9.14 & 7.71 \\
\hline $\mathrm{H}_{2} \mathrm{O}$ & 4.52 & 4.31 & 4.17 & 4.24 & 3.98 & 3.26 & 3.19 & 3.36 & 3.39 \\
\hline $\mathrm{F}$ & 0.03 & 0.34 & 0.32 & 0.18 & 0.22 & 0.59 & 0.71 & 0.40 & 0.36 \\
\hline $\mathrm{Cl}$ & 0.00 & 0.01 & 0.01 & 0.02 & 0.02 & 0.45 & 0.45 & 0.46 & 0.41 \\
\hline Total & 99.91 & 99.95 & 99.01 & 99.34 & 97.88 & 99.96 & 99.80 & 99.76 & 99.62 \\
\hline $\mathrm{Fe}$ & 0.48 & 4.03 & 5.19 & 8.47 & 13.90 & 25.31 & 25.17 & 24.36 & 25.26 \\
\hline $\mathrm{Mg}$ & 0.00 & 0.76 & 0.00 & 1.20 & 1.16 & 1.65 & 1.77 & 2.48 & 3.02 \\
\hline $\mathrm{Fe} /(\mathrm{Fe}+\mathrm{Mg})$ & 1.00 & 0.76 & 1.00 & 0.81 & 0.88 & 0.90 & 0.90 & 0.86 & 0.84 \\
\hline
\end{tabular}

Analytical error, based on 12 replicate analyses of standard reference material Biot5. Errors for $\mathrm{CaO}$ and $\mathrm{Na}_{2} \mathrm{O}$ were obtained from Kakanui hornblende due to low concentrations in Biot5. Data from 2 separate analytical sessions are as follows: $\mathrm{SiO}_{2} \pm 0.30$ wt. $\%$, $\mathrm{TiO}_{2} \pm 0.1$ wt. $\%, \mathrm{Al}_{2} \mathrm{O}_{3} \pm 0.10$ wt. $\%, \mathrm{MgO} \pm 0.11$ wt. $\%, \mathrm{CaO} \pm 0.11$ wt. $\%, \mathrm{MnO} \pm 0.02$ wt. $\%$, $\mathrm{FeO} \pm 0.10$ wt. $\%, \mathrm{Na}_{2} \mathrm{O} \pm 0.13$ wt. $\%, \mathrm{~K}_{2} \mathrm{O} \pm 0.03$ wt. $\%, \mathrm{~F} \pm 0.04$ wt. $\%$, and $\mathrm{Cl} \pm 0.01$ wt. $\%$.

chemically related. Amphiboles from a third sample of the hornblende granite (NM19) and the one amphibole-containing sample of anorthosite (NM312) define a wide compositional trend, particularly with respect to Fe and $\mathrm{Mg}$ (Fig. 8), although a subset of points from each of these samples is similar to the first-described set of amphiboles. The anorthosite sample is extensively altered, and the sample of the hornblende granite exhibits well-defined patchy zoning in the amphibole, which may also be a result of alteration. Therefore, the spread of amphibole compositions in these samples is interpreted as a secondary effect, related to alteration. It is likely that the original amphibole composition of the hornblende granite was similar to the other granite samples, based on the presence of several amphiboles in this sample that are indistinguishable from those in the other granite samples.

\section{Micas}

A total of 50 points were analyzed from the micas of the biotite-hornblende, hornblende, and miarolitic biotite granites (Table 5, Appendix 5). Biotites are found in the hornblende and biotitehornblende granite, whereas primary muscovite is found only in the miarolitic biotite granite. The biotites of the biotite-hornblende and hornblende granites are annites (Fig. 9), and show the Fe-enrichment typical of the biotites of A-type granites (cf. Anderson 1983, Elliott 2001), with Fe/ $(\mathrm{Fe}+\mathrm{Mg}$ ) ranging from 0.7 to 1.0 . The biotites of the biotite-hornblende granite have lower average $\mathrm{Fe} /(\mathrm{Fe}+\mathrm{Mg})(0.86)$ than the biotites of the hornblende granite (0.90). These values are within the range of biotites from A-type granites in the subsurface of west Texas and eastern New Mexico (Barnes et al. 1999) and the Red Bluff Granite in west Texas (Shannon et al. 1997). 

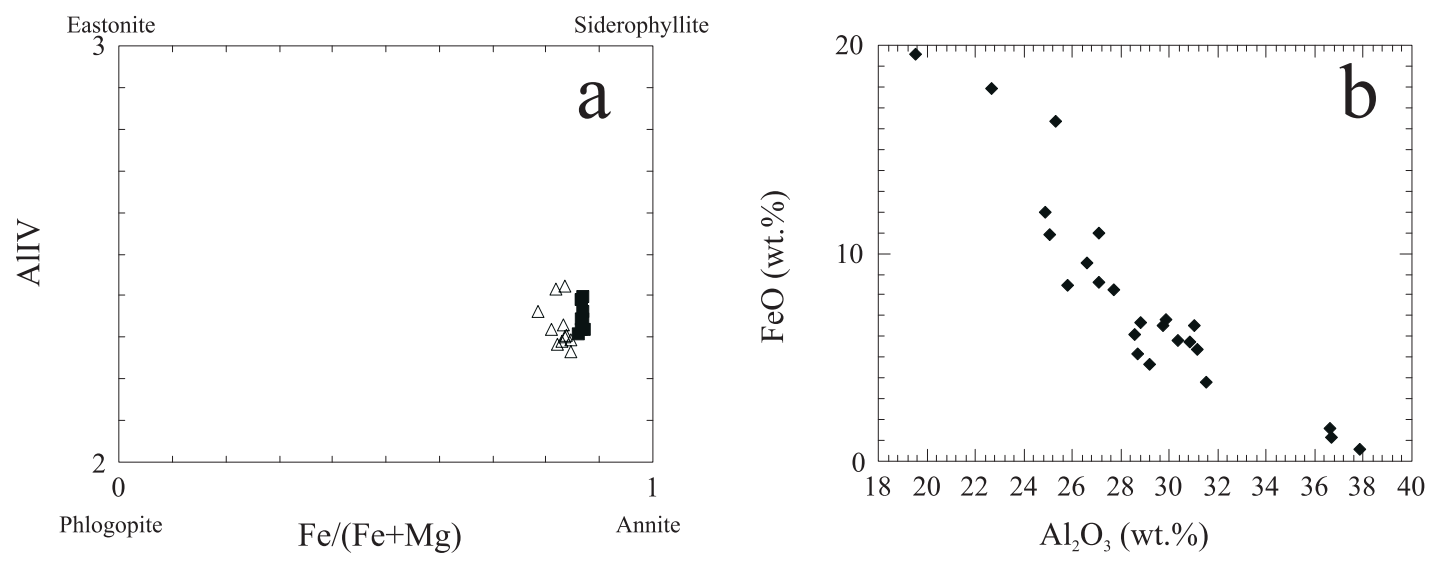

- hornblende granite (NM1)

$\Delta$ biotite-hornblende granite (NM9398)

- miarolitic biotite granite (NM11)

Fig. 9. Composition of biotites of the Redrock Granite. Analytical errors are found in Table 5.

The composition of micas in the miarolitic biotite granite varies widely (Table 5, Fig. 9, Appendix 5). When observed in BSE, the micas appear highly altered. Of the muscovites found in the miarolitic biotite granite, some may be near-primary, but much of the observed compositional variation is likely to be the result of secondary alteration. The magmatic and hydrothermal muscovites in these samples do not appear to show systematic compositional differences; however, some magmatic muscovites contain significant $\mathrm{TiO}_{2}$ (up to near 0.5 wt.\%), whereas the hydrothermal muscovites contain virtually none. Barbarin (1996) suggests that magmatic muscovite should contain higher $\mathrm{TiO}_{2}$ than that formed by hydrothermal fluids. The magmatic muscovite in these samples may have undergone variable degrees of chemical exchange with hydrothermal fluids, whereby higher $\mathrm{TiO}_{2}$ muscovite may have been altered to lower $\mathrm{TiO}_{2}$ hydrothermal muscovite.

\section{Degree of alteration as assessed by mineral chemistry}

Mineral chemistry assessed by microbeam analyses, as well as observation of the samples using
BSE imaging, allow the assessment of the degree and style of alteration that a rock has undergone. Within the samples of anorthosite, biotite-hornblende granite, hornblende granite, and miarolitic biotite granite that have been analyzed as part of this study, a range of degrees of alteration is observed. All analyzed anorthosite samples appear to be strongly altered. Little of the original igneous texture remains, and the compositions of feldspars and amphiboles are not representative of original igneous phases. The samples of granite, however, appear to be much less chemically disturbed. Some feldspar compositions may not be representative of original igneous compositions, but this is due to high temperature exsolution rather than low temperature alteration. The amphibole of one hornblende granite sample (NM19) and the mica of the miarolitic granite (sample NM11) appear to have undergone chemical alteration, but the other phases in these two rocks appear unaffected, suggesting that alteration was selective rather than pervasive. The remaining biotite-hornblende and hornblende granite samples exhibit primary igneous textures as well as apparently unaltered mineral compositions, suggesting that the compositions of these rocks are pristine. 


\section{WHOLE ROCK GEOCHEMISTRY}

The chemical compositions of the anorthosites and the different phases of the Redrock Granite are given in Table 6 and shown in Figures 10 through 13.

\section{Anorthosites}

The anorthosite/leucogabbro xenoliths are characterized by high $\mathrm{CaO}(8-12 \%), \mathrm{MgO}(0.3-5 \%)$, $\mathrm{Al}_{2} \mathrm{O}_{3}(13-29 \%), \mathrm{Sr}(257-551 \mathrm{ppm})$, and $\mathrm{Rb}(32-$ $261 \mathrm{ppm})$, and low $\mathrm{SiO}_{2}(46-51 \%), \mathrm{K}_{2} \mathrm{O}(0.6-2$ $\%)$, and $\mathrm{Cr}$ (8-41 ppm; Table 6, Fig. 11). For comparison, the Chipoco anorthosite-gabbro complex $(\sim 1000 \mathrm{Ma})$ in eastern Mexico is characterized by high $\mathrm{CaO}(7-13 \%), \mathrm{MgO}(1-5 \%), \mathrm{Al}_{2} \mathrm{O}_{3}(9-27$ $\%)$, and $\mathrm{Sr}(168-1266 \mathrm{ppm})$, and low $\mathrm{SiO}_{2}(37-$ $56 \%), \mathrm{K}_{2} \mathrm{O}$ (0-2 \%), and $\mathrm{Rb}$ (3-25 ppm; Lawlor et al. 1999). The Redrock anorthosites are similar in chemistry to massif-type anorthosites worldwide even though they are altered (Simmons \& Hanson 1978, Easton 1990, Ashwal 1993). Some of the analyses are high in $\mathrm{SiO}_{2}$ and $\mathrm{K}_{2} \mathrm{O}$, which is consistent with contact metamorphism or hydrothermal alteration of the anorthosites by the Redrock Granite (Table 6). The moderate to large positive Eu anomaly in the chondrite-normalized REE diagram (Fig. 13) is characteristic of anorthosites (Ashwal 1993).

\section{Redrock Granite}

The Redrock Granite is the most variable in composition of the four identified plutons in the Burro Mountains (McLemore et al. 2000b); it varies from alkali granite to quartz monzonite (according to the classification scheme of de la Roche et al. 1980). The Redrock Granite is a metaluminous to peraluminous and marginally alkaline to subalkaline (Fig. 10) A-type granite. The miarolitic biotite granite phase is slightly peraluminous, which is consistent with the presence of garnet and muscovite (cf. Barbarin 1996). The older biotitehornblende and hornblende granite phases are predominantly metaluminous with the biotite-hornblende granite being more peraluminous. The average $\mathrm{A} / \mathrm{CNK}$ and agpaitic index (molecular
$\left.\left(\mathrm{Na}_{2} \mathrm{O}+\mathrm{K}_{2} \mathrm{O}\right) / \mathrm{Al}_{2} \mathrm{O}_{3}\right)$ are 1.06 and 0.83 , respectively. For comparison, the averages for the Finnish rapakivi granites are 0.99 and 0.82 (Rämö \& Haapala 1995), and the averages for A-type granites in the subsurface of west Texas and eastern New Mexico are 1.07 and 0.67 (Barnes et al. 1999).

The four phases of the Redrock Granite (biotitehornblende granite, hornblende granite, miarolitic biotite granite, and alkali feldspar granite) are similar in bulk geochemical composition as well as mineral chemistry (Figs. 11, 12, 13), which implies a comagmatic relationship. The granites increase in $\mathrm{SiO}_{2}, \mathrm{U}$, Th, and $\mathrm{Rb}$, and decrease in $\mathrm{TiO}_{2}$, total $\mathrm{Fe}$ (calculated as $\mathrm{Fe}_{2} \mathrm{O}_{3}$ ), $\mathrm{MnO}, \mathrm{CaO}$, $\mathrm{P}_{2} \mathrm{O}_{5}, \mathrm{Zr}, \mathrm{Y}, \mathrm{Zn}$, and $\mathrm{Ba}$ from the hornblende and biotite-hornblende granite to the miarolitic biotite granite. This is consistent with the miarolitic biotite granite being the last to crystallize relative to the biotite-hornblende and hornblende granites. For comparison, the Red Bluff Granite shows a similar increase in $\mathrm{SiO}_{2}, \mathrm{Rb}$, Th, and $\mathrm{U}$, and decrease in $\mathrm{TiO}_{2}$, total $\mathrm{Fe}, \mathrm{MnO}, \mathrm{Zr}, \mathrm{P}, \mathrm{V}, \mathrm{Ba}$, and Sr from stage 1 (oldest) to stage 5 (youngest; Shannon et al. 1997). High Fe/Mg is typical of Atype and rapakivi granites (see Rämö \& Haapala 1995), and is also observed in the hornblende and biotite-hornblende granite phases of the Redrock Granite. In the miarolitic biotite granite, the ratio is lower $(0.79$, on average $)$ and shows a wider range of variation (Fig. 12, Table 6).

The A-type affinities of the Redrock Granite are well established. The four phases of the Redrock Granite have $\mathrm{Rb} / \mathrm{Sr}>1, \mathrm{~K}_{2} \mathrm{O} / \mathrm{Na}_{2} \mathrm{O}>1, \mathrm{Nb}>5 \mathrm{ppm}$, $\mathrm{V}<25 \mathrm{ppm}$, and $\mathrm{Cr}<100 \mathrm{ppm}$, typical of A-type granites and the Finnish rapakivi granites (Whalen et al. 1987, Eby 1990, Rämö 1991). The Redrock Granite has average $\mathrm{Rb} / \mathrm{Ba}$ and $\mathrm{Rb} / \mathrm{Sr}$ (1.6 and 7.6, respectively) relatively close to those of the Finnish rapakivi granites (2.1 and 9.8, Rämö and Haapala 1995), although the amounts of the elements vary noticeably (Table 6). The contents of fluorine in the Redrock Granite (871 ppm, on average) are lower than in the Finnish rapakivi granites (average 3,500, range from 400 to 15,300 ppm; Rämö \& Haapala 1995), which is consistent with the absence of highly-fractionated topazbearing phases in the Redrock Granite. In the Ga/ 
TABLE 6. Whole rock geochemical analyses of the fine-grained alkali feldspar and biotite granite dikes, the different phases of the Redrock Granite, and the anorthosites. $\mathrm{Fe}_{2} \mathrm{O}_{3} \mathrm{~T}$-Iron reported as total $\mathrm{Fe}_{2} \mathrm{O}_{3}$.

Fine-grained alkali feldspar and biotite granite dikes

\begin{tabular}{|c|c|c|c|c|c|c|c|c|c|c|}
\hline SAMPLE & $\begin{array}{r}\mathrm{NM} \\
20-98\end{array}$ & $\begin{array}{r}\text { NM } \\
22-98\end{array}$ & $\begin{array}{r}\mathrm{NM} \\
49-98\end{array}$ & $\begin{array}{r}\text { NM } \\
79-98\end{array}$ & $\begin{array}{r}\text { NM } \\
84-98\end{array}$ & $\begin{array}{r}\mathrm{NM} \\
94-98\end{array}$ & $\begin{array}{r}\mathrm{NM} \\
95-98\end{array}$ & $\begin{array}{r}\text { NM } \\
161-99\end{array}$ & $\begin{array}{r}\text { NM } \\
235-99\end{array}$ & $\begin{array}{r}\text { NM } \\
290-99\end{array}$ \\
\hline $\mathrm{SiO}_{2}$ & 77.63 & 63.56 & 74.24 & 77.06 & 74.08 & 76.54 & 72.32 & 79.57 & 75.26 & 73.79 \\
\hline $\mathrm{TiO}_{2}$ & 0.06 & 0.8 & 0.17 & 0.03 & 0.22 & 0.02 & 0.01 & 0.08 & 0.08 & 0.34 \\
\hline $\mathrm{Al}_{2} \mathrm{O}_{3}$ & 12.48 & 15.66 & 13.68 & 12.63 & 13.27 & 12.74 & 14.25 & 12.09 & 13.82 & 13.29 \\
\hline $\mathrm{Fe}_{2} \mathrm{O}_{3} \mathrm{~T}$ & 0.38 & 5.54 & 1.28 & 0.14 & 2.21 & 0.36 & 0.23 & 0.98 & 0.85 & 2.55 \\
\hline $\mathrm{MgO}$ & 0.07 & 2.03 & 0.46 & 0.01 & 0.24 & 0.03 & 0.05 & 0.07 & 0.15 & 1.37 \\
\hline $\mathrm{CaO}$ & 0.18 & 2.52 & 0.32 & 0.10 & 0.78 & 0.37 & 1.67 & 0.18 & 0.43 & 0.92 \\
\hline $\mathrm{Na}_{2} \mathrm{O}$ & 3.71 & 4.05 & 3.57 & 4.57 & 3.34 & 3.54 & 3.38 & 4.16 & 3.15 & 3.49 \\
\hline $\mathrm{K}_{2} \mathrm{O}$ & 4.73 & 3.80 & 5.49 & 4.25 & 5.22 & 5.80 & 7.23 & 3.84 & 6.04 & 3.50 \\
\hline $\mathrm{MnO}$ & $<0.01$ & 0.09 & 0.02 & $<0.01$ & 0.04 & 0.01 & $<0.01$ & n.d. & 0.01 & 0.04 \\
\hline $\mathrm{P}_{2} \mathrm{O}_{5}$ & 0.01 & 0.19 & 0.07 & 0.03 & 0.09 & 0.01 & 0.01 & 0.03 & 0.04 & 0.17 \\
\hline LOI & 0.73 & 2.10 & 0.64 & 0.33 & 0.49 & 0.37 & 0.80 & 0.34 & 0.49 & 1.45 \\
\hline TOTAL & 99.98 & 100.34 & 99.94 & 99.15 & 99.98 & 99.79 & 99.95 & 101.34 & 100.31 & 100.91 \\
\hline $\mathrm{Fe}_{2} \mathrm{O}_{3}$ & 0.12 & 2.63 & 0.99 & & 0.25 & 0.23 & & & & \\
\hline $\mathrm{FeO}$ & 0.24 & 2.65 & 0.26 & 0.38 & 1.78 & 0.54 & 0.51 & & & \\
\hline As & $<1$ & 2 & 1 & $<1$ & 1 & $<1$ & $<1$ & 3 & 2 & 1 \\
\hline $\mathrm{Ga}$ & 27 & 20 & 15 & 19 & 20 & 28 & 28 & 21 & 12 & 17 \\
\hline $\mathrm{Zn}$ & 14 & 80 & 12 & 4 & 39 & 8 & 3 & 76 & 9 & 40 \\
\hline $\mathrm{Cu}$ & $<1$ & 46 & $<1$ & $<1$ & $<1$ & $<1$ & $<1$ & 19 & 56 & 11 \\
\hline Mo & $<1$ & 1 & $<1$ & 1 & $<1$ & 1 & $<1$ & $<1$ & $<1$ & n.d. \\
\hline $\mathrm{Ni}$ & $<1$ & 10 & 8 & 2 & 3 & 2 & 3 & 12 & 5 & 27 \\
\hline $\mathrm{Ba}$ & 142 & 929 & 802 & 146 & 484 & 41 & 48 & 2100 & 867 & 669 \\
\hline $\mathrm{V}$ & $<2$ & 112 & 16 & 5 & 7 & $<2$ & 4 & 67 & 9 & 41 \\
\hline $\mathrm{Cr}$ & 6 & 6 & 12 & 4 & 7 & 5 & 5 & 17 & 8 & 48 \\
\hline $\mathrm{Pb}$ & 14 & 22 & 39 & 6 & 31 & 35 & 44 & 22 & 56 & 27 \\
\hline $\mathrm{Th}$ & 27 & 21 & 16 & 23 & 37 & 11 & 11 & $<1$ & 3 & 23 \\
\hline $\mathrm{Rb}$ & 305 & 184 & 230 & 199 & 343 & 969 & 1024 & 134 & 152 & 112 \\
\hline $\mathrm{U}$ & 5 & 4 & 4 & 7 & 6 & 9 & 5 & 3 & 3 & 5 \\
\hline $\mathrm{Sr}$ & 17 & 315 & 170 & 30 & 67 & 8 & 19 & 339 & 328 & 401 \\
\hline $\mathrm{Y}$ & 25 & 38 & 27 & 45 & 109 & 125 & 512 & 49 & 9 & 14 \\
\hline $\mathrm{Zr}$ & 63 & 269 & 90 & 76 & 239 & 50 & 48 & 401 & 30 & 152 \\
\hline $\mathrm{Nb}$ & 22 & 10 & 12 & 19 & 24 & 17 & 8 & 9 & $<1$ & 3 \\
\hline \multicolumn{11}{|l|}{$\mathrm{Sn}$} \\
\hline \multicolumn{11}{|l|}{$\mathrm{F}$} \\
\hline $\mathrm{La}$ & & & & & & 28.2 & & & & \\
\hline $\mathrm{Ce}$ & & & & & & 69.6 & & & & \\
\hline $\operatorname{Pr}$ & & & & & & 9 & & & & \\
\hline $\mathrm{Nd}$ & & & & & & 36 & & & & \\
\hline $\mathrm{Sm}$ & & & & & & 10.6 & & & & \\
\hline $\mathrm{Eu}$ & & & & & & 0.09 & & & & \\
\hline $\mathrm{Gd}$ & & & & & & 10.7 & & & & \\
\hline $\mathrm{Tb}$ & & & & & & 2.1 & & & & \\
\hline Dy & & & & & & 17.2 & & & & \\
\hline Ho & & & & & & 3.65 & & & & \\
\hline $\mathrm{Er}$ & & & & & & 13.9 & & & & \\
\hline $\mathrm{Tm}$ & & & & & & 2.6 & & & & \\
\hline $\mathrm{Yb}$ & & & & & & 21.7 & & & & \\
\hline $\mathrm{Lu}$ & & & & & & 3.32 & & & & \\
\hline
\end{tabular}


TABLE 6. Continued

\begin{tabular}{|c|c|c|c|c|c|c|c|c|c|}
\hline & Miarol & c biotite & anite & & & & & & \\
\hline SAMPLE & E $\quad$ B & $\mathrm{B}$ & B & B & B & NM & $\mathrm{NM}$ & RED & RED \\
\hline & 16.1R & $16.2 \mathrm{R}$ & 9.1 & 9.8 & 9.9 & 77.98 & 106-98 & 3 & 5 \\
\hline $\mathrm{SiO}_{2}$ & 72.10 & 76.20 & 76.20 & 73.80 & 76.00 & 76.17 & 77.30 & 77.03 & 60.51 \\
\hline $\mathrm{TiO}_{2}$ & 0.29 & 0.06 & 1.44 & 0.28 & 0.09 & 0.07 & 0.13 & 0.11 & 1.43 \\
\hline $\mathrm{Al}_{2} \mathrm{O}_{3}$ & 13.50 & 12.80 & 12.40 & 13.30 & 12.20 & 12.32 & 12.03 & 12.57 & 13.66 \\
\hline $\mathrm{Fe}_{2} \mathrm{O}_{3} \mathrm{~T}$ & 2.24 & 0.96 & 0.56 & 2.04 & 1.58 & 0.95 & 1.51 & 0.74 & 8.09 \\
\hline $\mathrm{MgO}$ & 1.51 & 0.48 & 0.62 & 0.20 & 0.37 & 0.08 & 0.18 & 0.16 & 2.55 \\
\hline $\mathrm{CaO}$ & 0.70 & 0.27 & 0.61 & 0.61 & 0.62 & 0.81 & 0.49 & 0.25 & 10.71 \\
\hline $\mathrm{Na}_{2} \mathrm{O}$ & 4.04 & 4.66 & 3.48 & 3.36 & 3.66 & 3.75 & 2.99 & 2.79 & 0.74 \\
\hline $\mathrm{K}_{2} \mathrm{O}$ & 4.91 & 3.61 & 5.11 & 5.16 & 4.74 & 4.81 & 5.13 & 5.91 & 0.28 \\
\hline $\mathrm{MnO}$ & 0.04 & 0.02 & 0.02 & 0.01 & 0.03 & 0.02 & 0.01 & 0.01 & 0.09 \\
\hline $\mathrm{P}_{2} \mathrm{O}_{5}$ & 0.17 & 0.02 & 0.01 & 0.09 & 0.03 & 0.01 & 0.07 & 0.03 & 0.49 \\
\hline LOI & 1.33 & 0.69 & 0.73 & 2.26 & 1.11 & 0.99 & 0.57 & 0.55 & 2.42 \\
\hline TOTAL & 100.83 & 99.77 & 101.18 & 101.11 & 100.43 & 99.98 & 100.41 & 100.15 & 100.97 \\
\hline $\mathrm{Fe}_{2} \mathrm{O}_{3}$ & 1.68 & 0.82 & 0.2 & 1.13 & 0.84 & 0.36 & 0.64 & 0.12 & 4.79 \\
\hline $\mathrm{FeO}$ & 0.51 & 0.13 & 0.16 & 0.49 & 0.67 & 0.54 & 0.79 & 0.56 & 3 \\
\hline As & & & & & & $<1$ & $<1$ & $<1$ & 1 \\
\hline $\mathrm{Ga}$ & 20 & 20 & 20 & 13 & 19 & 26 & 17 & 18 & 27 \\
\hline $\mathrm{Zn}$ & 45 & 43 & 18 & 20 & 27 & 25 & 18 & 10 & 65 \\
\hline $\mathrm{Cu}$ & 7 & 10 & 6 & 6 & 12 & $<1$ & $<1$ & $<1$ & $<1$ \\
\hline Mo & & & & & & $<1$ & $<1$ & $<1$ & $<1$ \\
\hline $\mathrm{Ni}$ & 8 & 9 & 4 & 5 & 5 & 2 & 2 & 2 & 4 \\
\hline $\mathrm{Ba}$ & 1699 & 144 & 159 & 612 & 188 & 285 & 325 & 290 & 102 \\
\hline V & 14 & $<2$ & 3 & 14 & 2 & $<2$ & $<2$ & 4 & $<2$ \\
\hline $\mathrm{Cr}$ & 8 & $<2$ & 6 & 11 & 11 & 5 & 7 & $<1$ & $<1$ \\
\hline $\mathrm{Pb}$ & 27 & 49 & 24 & 23 & 30 & 30 & 22 & 11 & 65 \\
\hline $\mathrm{Th}$ & 48 & 22 & 26 & 31 & 35 & 42 & 21 & 40 & 17 \\
\hline $\mathrm{Rb}$ & 504 & 221 & 272 & 174 & 383 & 305 & 263 & 296 & 7 \\
\hline $\mathrm{U}$ & 6.9 & 11 & 13 & 7 & 10 & 11 & 6 & 6 & 8 \\
\hline $\mathrm{Sr}$ & 91 & 37 & 42 & 84 & 41 & 29 & 64 & 51 & 400 \\
\hline Y & 62 & 12 & 57 & 79 & 60 & 98 & 47 & 55 & 166 \\
\hline $\mathrm{Zr}$ & 327 & 52 & 69 & 253 & 130 & 142 & 190 & 152 & 306 \\
\hline $\mathrm{Nb}$ & 19 & 13 & 19 & 25 & 16 & 32 & 10 & 21 & 37 \\
\hline $\mathrm{Sn}$ & & & & & & 5 & $<5$ & & \\
\hline $\mathrm{F}$ & & & & & & 1230 & 222 & & \\
\hline $\mathrm{La}$ & & & & & & 43.9 & 71.3 & & \\
\hline $\mathrm{Ce}$ & & & & & & 103 & 147 & & \\
\hline $\operatorname{Pr}$ & & & & & & 12.7 & 15.5 & & \\
\hline $\mathrm{Nd}$ & & & & & & 50.9 & 55 & & \\
\hline $\mathrm{Sm}$ & & & & & & 11.8 & 9.7 & & \\
\hline $\mathrm{Eu}$ & & & & & & 1.19 & 1.07 & & \\
\hline $\mathrm{Gd}$ & & & & & & 12.1 & 8.5 & & \\
\hline $\mathrm{Tb}$ & & & & & & 2.1 & 1.2 & & \\
\hline Dy & & & & & & 15.4 & 7.6 & & \\
\hline Ho & & & & & & 3.24 & 1.47 & & \\
\hline $\mathrm{Er}$ & & & & & & 11 & 4.5 & & \\
\hline $\mathrm{Tm}$ & & & & & & 1.7 & 0.6 & & \\
\hline $\mathrm{Yb}$ & & & & & & 13.1 & 4.4 & & \\
\hline $\mathrm{Lu}$ & & & & & & 1.97 & 0.59 & & \\
\hline
\end{tabular}


TABLE 6. Continued

\begin{tabular}{|c|c|c|c|c|c|c|c|c|c|c|}
\hline \multicolumn{6}{|c|}{ Miarolitic biotite granite } & \multicolumn{2}{|c|}{$\begin{array}{l}\text { Alkali feldspar } \\
\text { granite }\end{array}$} & \multicolumn{3}{|c|}{ Hornblende granite } \\
\hline SAMPLE & RED & RED & NM & NM & NM & RED & NM & NM & NM & RED \\
\hline & 6 & 10 & $4-96$ & $8-96$ & $11-96$ & 9 & $76-98$ & $19-98$ & $131-98$ & 14 \\
\hline $\mathrm{SiO}_{2}$ & 64.13 & 76.22 & 75.37 & 80.02 & 77.70 & 78.98 & 76.24 & 69.79 & 69.51 & 72.63 \\
\hline $\mathrm{TiO}_{2}$ & 0.69 & 0.13 & 0.17 & 0.05 & 0.05 & 0.05 & 0.06 & 0.41 & 0.53 & 0.33 \\
\hline $\mathrm{Al}_{2} \mathrm{O}_{3}$ & 14.11 & 12.05 & 12.91 & 11.87 & 12.79 & 12.31 & 12.48 & 13.58 & 14.22 & 12.71 \\
\hline $\mathrm{Fe}_{2} \mathrm{O}_{3} \mathrm{~T}$ & 8.10 & 1.60 & 0.75 & 0.49 & 0.56 & 0.26 & 0.45 & 4.74 & 4.30 & 3.01 \\
\hline $\mathrm{MgO}$ & 0.22 & 0.11 & 0.17 & 0.03 & 0.09 & 0.03 & 0.05 & 0.09 & 0.33 & 0.09 \\
\hline $\mathrm{CaO}$ & 2.33 & 0.50 & 0.64 & 0.13 & 0.33 & 0.19 & 1.10 & 1.47 & 1.56 & 0.71 \\
\hline $\mathrm{Na}_{2} \mathrm{O}$ & 3.33 & 2.71 & 2.97 & 3.70 & 3.55 & 4.53 & 4.59 & 4.12 & 3.54 & 3.39 \\
\hline $\mathrm{K}_{2} \mathrm{O}$ & 5.85 & 5.67 & 5.77 & 4.24 & 4.66 & 3.44 & 3.81 & 5.05 & 5.16 & 5.72 \\
\hline $\mathrm{MnO}$ & 0.15 & 0.01 & 0.01 & $<0.01$ & 0.05 & $<0.01$ & 0.01 & 0.10 & 0.09 & 0.06 \\
\hline $\mathrm{P}_{2} \mathrm{O}_{5}$ & 0.13 & 0.03 & 0.06 & 0.01 & 0.01 & 0.02 & 0.01 & 0.05 & 0.11 & 0.08 \\
\hline LOI & 0.27 & 0.37 & 0.79 & 0.35 & 0.63 & 0.33 & 1.12 & 0.47 & 0.41 & 0.45 \\
\hline TOTAL & 99.31 & 99.40 & 99.61 & 100.89 & 100.42 & 100.14 & 99.92 & 99.87 & 99.76 & 99.18 \\
\hline $\mathrm{Fe}_{2} \mathrm{O}_{3}$ & 2.93 & 0.46 & 0.09 & 0.05 & 0.04 & & 0.03 & 1.06 & 0.64 & 0.74 \\
\hline $\mathrm{FeO}$ & 4.7 & 1.04 & 0.6 & 0.4 & 0.47 & 0.55 & 0.38 & 3.35 & 3.33 & 2.06 \\
\hline As & 1 & 2 & $<1$ & 2 & $<1$ & 4 & $<1$ & 2 & 3 & 4 \\
\hline $\mathrm{Ga}$ & 23 & 19 & 20 & 26 & 18 & 27 & 24 & 26 & 22 & 23 \\
\hline $\mathrm{Zn}$ & 96 & 23 & 18 & 3 & 30 & 3 & 8 & 110 & 85 & 76 \\
\hline $\mathrm{Cu}$ & 4 & 4 & $<1$ & $<1$ & $<1$ & $<1$ & $<1$ & 2 & 8 & $<1$ \\
\hline Mo & 2 & 1 & $<1$ & $<1$ & 1 & $<1$ & 13 & 3 & 2 & 2 \\
\hline $\mathrm{Ni}$ & 3 & $<1$ & 3 & 2 & $<1$ & 3 & 2 & 2 & 4 & 2 \\
\hline $\mathrm{Ba}$ & 2150 & 509 & 329 & 115 & 18 & 103 & 183 & 772 & 1210 & 499 \\
\hline V & $<2$ & $<2$ & 9 & 7 & 5 & 7 & 5 & 2 & 11 & 4 \\
\hline $\mathrm{Cr}$ & 6 & $<1$ & 7 & $<1$ & 4 & $<1$ & $<1$ & 4 & 9 & $<1$ \\
\hline $\mathrm{Pb}$ & 17 & 30 & 20 & 20 & 25 & 26 & 9 & 27 & 31 & 31 \\
\hline Th & 10 & 19 & 33 & 63 & 22 & 53 & 33 & 18 & 20 & 25 \\
\hline $\mathrm{Rb}$ & 175 & 399 & 326 & 367 & 388 & 270 & 252 & 248 & 257 & 271 \\
\hline $\mathrm{U}$ & 2 & 3 & 10 & 19 & 10 & 13 & 12 & 6 & 6 & 5 \\
\hline $\mathrm{Sr}$ & 100 & 48 & 64 & 11 & 20 & 12 & 24 & 42 & 95 & 35 \\
\hline $\mathrm{Y}$ & 91 & 47 & 79 & 139 & 56 & 120 & 123 & 106 & 97 & 96 \\
\hline $\mathrm{Zr}$ & 600 & 131 & 249 & 228 & 55 & 155 & 118 & 724 & 505 & 484 \\
\hline $\mathrm{Nb}$ & 18 & 14 & 33 & 70 & 39 & 66 & 38 & 33 & 22 & 28 \\
\hline $\mathrm{Sn}$ & & & & & & & 5 & 18 & 7 & \\
\hline $\mathrm{F}$ & & & & & & & 418 & 1710 & 1740 & \\
\hline $\mathrm{La}$ & & & & & & & 20.9 & 44 & 53.7 & \\
\hline $\mathrm{Ce}$ & & & & & & & 57.4 & 103 & 125 & \\
\hline $\operatorname{Pr}$ & & & & & & & 7.7 & 12.9 & 15.4 & \\
\hline $\mathrm{Nd}$ & & & & & & & 32.7 & 57.1 & 66.2 & \\
\hline $\mathrm{Sm}$ & & & & & & & 8.6 & 13.9 & 15.3 & \\
\hline $\mathrm{Eu}$ & & & & & & & 0.76 & 3.21 & 3.1 & \\
\hline $\mathrm{Gd}$ & & & & & & & 10.1 & 14.8 & 15.9 & \\
\hline $\mathrm{Tb}$ & & & & & & & 2 & 2.3 & 2.4 & \\
\hline Dy & & & & & & & 15.7 & 16.6 & 17.2 & \\
\hline Ho & & & & & & & 3.7 & 3.36 & 3.41 & \\
\hline $\mathrm{Er}$ & & & & & & & 14 & 11.1 & 10.6 & \\
\hline $\mathrm{Tm}$ & & & & & & & 2.4 & 1.8 & 1.7 & \\
\hline $\mathrm{Yb}$ & & & & & & & 18.9 & 13.2 & 11.4 & \\
\hline $\mathrm{Lu}$ & & & & & & & 2.83 & 2.03 & 1.72 & \\
\hline
\end{tabular}


TABLE 6. Continued

\begin{tabular}{|c|c|c|c|c|c|c|c|c|c|c|c|}
\hline \multirow[b]{2}{*}{ SAMPLE } & \multicolumn{7}{|c|}{ Hornblende granite Biotite-hornblende granite } & \multicolumn{4}{|c|}{ Anorthosites } \\
\hline & $\begin{array}{l}\text { NM } \\
1-96\end{array}$ & $\begin{array}{r}\text { NM } \\
314-99\end{array}$ & $\begin{array}{r}\text { RED } \\
16\end{array}$ & $\begin{array}{r}\text { NM } \\
93-98\end{array}$ & $\begin{array}{r}\text { NM } \\
61-98\end{array}$ & $\begin{array}{r}\text { NM } \\
279-99\end{array}$ & $\begin{array}{r}\text { NM } \\
279 A-99\end{array}$ & $\begin{array}{r}\text { NM } \\
281-99\end{array}$ & $\begin{array}{r}\text { B } \\
9.2\end{array}$ & $\begin{array}{r}\text { B } \\
9.4\end{array}$ & $\begin{array}{r}\text { B } \\
9.5\end{array}$ \\
\hline $\mathrm{SiO}_{2}$ & 66.89 & 72.96 & 83.12 & 69.13 & 74.09 & 71.27 & 76.12 & 74.19 & 50.90 & 51.10 & 46.50 \\
\hline $\mathrm{TiO}_{2}$ & 0.60 & 0.40 & 0.17 & 0.59 & 0.34 & 0.44 & 0.38 & 0.38 & 1.44 & 0.98 & 3.51 \\
\hline $\mathrm{Al}_{2} \mathrm{O}_{3}$ & 14.33 & 12.64 & 7.40 & 14.15 & 12.63 & 13.89 & 13.48 & 14.25 & 20.30 & 22.10 & 13.90 \\
\hline $\mathrm{Fe}_{2} \mathrm{O}_{3} \mathrm{~T}$ & 6.23 & 3.23 & 4.52 & 4.81 & 2.62 & 3.42 & 0.48 & 0.53 & 6.10 & 5.60 & 13.70 \\
\hline $\mathrm{MgO}$ & 0.14 & 0.18 & 0.12 & 0.43 & 0.09 & 0.19 & 0.14 & 0.16 & 2.34 & 3.77 & 4.96 \\
\hline $\mathrm{CaO}$ & 1.80 & 0.70 & 0.09 & 1.33 & 0.34 & 0.93 & 0.21 & 0.31 & 9.30 & 10.50 & 9.17 \\
\hline $\mathrm{Na}_{2} \mathrm{O}$ & 3.90 & 3.05 & 0.06 & 3.28 & 3.08 & 3.66 & 2.75 & 3.31 & 4.33 & 4.01 & 3.72 \\
\hline $\mathrm{K}_{2} \mathrm{O}$ & 5.68 & 6.00 & 2.88 & 5.34 & 5.69 & 5.67 & 6.08 & 6.20 & 2.03 & 1.76 & 1.09 \\
\hline $\mathrm{MnO}$ & 0.11 & 0.06 & 0.01 & 0.10 & 0.05 & 0.06 & $<0.01$ & $<0.01$ & 0.11 & 0.09 & 0.24 \\
\hline $\mathrm{P}_{2} \mathrm{O}_{5}$ & 0.08 & 0.05 & 0.03 & 0.12 & 0.04 & 0.09 & 0.06 & 0.07 & 0.24 & 0.21 & 0.48 \\
\hline LOI & 0.63 & 0.55 & 1.63 & 0.52 & 0.94 & 0.64 & 1.08 & 0.90 & 2.00 & 2.31 & 1.60 \\
\hline TOTAL & 100.39 & 99.82 & 100.03 & 99.80 & 99.91 & 100.26 & 100.78 & 100.30 & 99.09 & 102.43 & 98.87 \\
\hline $\mathrm{Fe}_{2} \mathrm{O}_{3}$ & 1.74 & & 3.43 & 1.06 & 1.96 & & & & 1.8 & 1.65 & 2.5 \\
\hline $\mathrm{FeO}$ & 4.08 & & 0.99 & 3.41 & 0.6 & & & & 4.08 & 3.59 & 11 \\
\hline As & 2 & $<1$ & 1 & 1 & $<1$ & 2 & 2 & 3 & & & \\
\hline $\mathrm{Ga}$ & 25 & 20 & 14 & 21 & 20 & 23 & 23 & 23 & 22 & 22 & 21 \\
\hline $\mathrm{Zn}$ & 106 & 78 & 51 & 92 & 67 & 26 & 111 & 40 & 144 & 30 & 144 \\
\hline $\mathrm{Cu}$ & 7 & 6 & $<1$ & 7 & $<1$ & 7 & 6 & 9 & 53 & 5 & 6 \\
\hline Mo & 5 & 3 & 3 & 2 & 2 & $<1$ & 2 & $<1$ & & & \\
\hline $\mathrm{Ni}$ & 2 & 4 & 3 & 3 & 2 & 7 & 7 & 5 & 16 & 17 & 13 \\
\hline $\mathrm{Ba}$ & 1345 & 674 & 289 & 1353 & 648 & 555 & 742 & 662 & 448 & 351 & 181 \\
\hline $\mathrm{V}$ & $<2$ & 4 & 6 & 14 & 6 & 5 & 2 & 5 & 121 & 68 & 210 \\
\hline $\mathrm{Cr}$ & 5 & 6 & $<1$ & 8 & 5 & 9 & 5 & 9 & 25 & 29 & 20 \\
\hline $\mathrm{Pb}$ & 24 & 33 & 11 & 28 & 25 & 8 & 35 & 15 & 51 & 2 & 22 \\
\hline Th & 16 & 17 & 20 & 13 & 22 & 19 & 15 & 12 & 2 & 1 & 5 \\
\hline $\mathrm{Rb}$ & 171 & 200 & 126 & 182 & 216 & 243 & 218 & 225 & 146 & 119 & 51 \\
\hline $\mathrm{U}$ & 4 & 2 & 11 & 2 & 3 & 5 & 6 & 4 & 4 & 2 & 3 \\
\hline $\mathrm{Sr}$ & 60 & 46 & 20 & 115 & 42 & 31 & 64 & 51 & 415 & 439 & 257 \\
\hline $\mathrm{Y}$ & 96 & 108 & 86 & 71 & 104 & 77 & 101 & 58 & 24 & 15 & 39 \\
\hline $\mathrm{Zr}$ & 967 & 576 & 242 & 564 & 451 & 440 & 511 & 396 & 59 & 52 & 127 \\
\hline $\mathrm{Nb}$ & 21 & 34 & 18 & 20 & 23 & 21 & 20 & 17 & 4 & 4 & 11 \\
\hline $\mathrm{Sn}$ & 5 & & & 5 & 6 & & & & & & \\
\hline $\mathrm{F}$ & 480 & & & 844 & 324 & & & & & & \\
\hline $\mathrm{La}$ & 48.4 & & & 49.2 & 96.9 & & & & & & \\
\hline $\mathrm{Ce}$ & 124 & & & 110 & 182 & & & & & & \\
\hline $\operatorname{Pr}$ & 15.1 & & & 13.7 & 25.1 & & & & & & \\
\hline $\mathrm{Nd}$ & 66 & & & 59 & 104 & & & & & & \\
\hline $\mathrm{Sm}$ & 15.9 & & & 13.1 & 21.9 & & & & & & \\
\hline $\mathrm{Eu}$ & 4.8 & & & 3.21 & 2.49 & & & & & & \\
\hline $\mathrm{Gd}$ & 16.9 & & & 13.8 & 22.3 & & & & & & \\
\hline $\mathrm{Tb}$ & 2.4 & & & 1.9 & 3.1 & & & & & & \\
\hline Dy & 17.1 & & & 13.1 & 19.6 & & & & & & \\
\hline Ho & 3.38 & & & 2.46 & 3.65 & & & & & & \\
\hline $\mathrm{Er}$ & 10.2 & & & 7.6 & 10.5 & & & & & & \\
\hline $\mathrm{Tm}$ & 1.5 & & & 1 & 1.4 & & & & & & \\
\hline $\mathrm{Yb}$ & 10.2 & & & 7.1 & 9 & & & & & & \\
\hline $\mathrm{Lu}$ & 1.56 & & & 1.05 & 1.32 & & & & & & \\
\hline
\end{tabular}


TABLE 6. Continued

\begin{tabular}{|c|c|c|c|c|c|c|c|c|c|c|c|}
\hline \multirow[b]{2}{*}{ SAMPLE } & \multicolumn{7}{|c|}{ Anorthosites } & \multicolumn{4}{|c|}{ Altered anorthosites } \\
\hline & $\begin{array}{r}\text { NM } \\
85-98\end{array}$ & $\begin{array}{r}\text { RED } \\
1\end{array}$ & $\begin{array}{r}\text { RED } \\
2\end{array}$ & $\begin{array}{r}\text { RED } \\
4\end{array}$ & $\begin{array}{r}\text { RED } \\
7\end{array}$ & $\begin{array}{r}\text { NM } \\
3-98\end{array}$ & $\begin{array}{r}\text { RED } \\
11\end{array}$ & $\begin{array}{r}\text { NM } \\
312-99\end{array}$ & $\begin{array}{r}\text { B } \\
9.6\end{array}$ & $\begin{array}{r}\text { B } \\
9.7\end{array}$ & $\begin{array}{r}\text { B } \\
9.3\end{array}$ \\
\hline $\mathrm{SiO}_{2}$ & 50.19 & 50.18 & 50.89 & 51.36 & 49.25 & 50.60 & 50.50 & 49.41 & 71.70 & 74.00 & 70.80 \\
\hline $\mathrm{TiO}_{2}$ & 0.49 & 0.51 & 0.45 & 0.19 & 1.36 & 1.63 & 0.42 & 1.43 & 0.29 & 0.27 & 0.28 \\
\hline $\mathrm{Al}_{2} \mathrm{O}_{3}$ & 24.21 & 24.76 & 26.71 & 29.10 & 22.10 & 20.33 & 24.99 & 20.92 & 14.20 & 8.39 & 13.60 \\
\hline $\mathrm{Fe}_{2} \mathrm{O}_{3} \mathrm{~T}$ & 5.37 & 4.94 & 2.60 & 1.12 & 7.22 & 7.09 & 4.41 & 8.62 & 2.79 & 3.10 & 1.43 \\
\hline $\mathrm{MgO}$ & 3.11 & 1.71 & 0.77 & 0.30 & 2.02 & 1.63 & 2.98 & 2.51 & 1.98 & 1.40 & 1.03 \\
\hline $\mathrm{CaO}$ & 9.81 & 9.56 & 9.42 & 12.11 & 9.92 & 9.17 & 10.23 & 8.50 & 1.51 & 4.31 & 1.70 \\
\hline $\mathrm{Na}_{2} \mathrm{O}$ & 3.53 & 3.66 & 3.74 & 4.08 & 3.78 & 4.30 & 3.57 & 3.76 & 3.65 & 2.70 & 3.29 \\
\hline $\mathrm{K}_{2} \mathrm{O}$ & 1.61 & 2.10 & 2.72 & 0.58 & 1.48 & 1.64 & 1.41 & 1.96 & 5.45 & 2.02 & 6.02 \\
\hline $\mathrm{MnO}$ & 0.08 & 0.07 & 0.04 & 0.01 & 0.11 & 0.11 & 0.06 & 0.12 & 0.04 & 0.08 & 0.03 \\
\hline $\mathrm{P}_{2} \mathrm{O}_{5}$ & 0.10 & 0.11 & 0.09 & 0.03 & 0.34 & 0.42 & 0.08 & 0.22 & 0.15 & 0.05 & 0.16 \\
\hline LOI & 2.06 & 2.89 & 3.04 & 1.16 & 2.16 & 2.19 & 2.01 & 2.60 & 0.96 & 4.01 & 2.59 \\
\hline TOTAL & 100.56 & 100.49 & 100.47 & 100.04 & 99.74 & 99.11 & 100.66 & 100.05 & 102.72 & 100.33 & 100.93 \\
\hline $\mathrm{Fe}_{2} \mathrm{O}_{3}$ & 0.6 & 0.83 & 0.08 & 0.19 & 1.28 & & 0.38 & & 0.85 & 0.97 & 0.68 \\
\hline $\mathrm{FeO}$ & 4.34 & 3.74 & 2.29 & 1.19 & 5.4 & & 3.66 & & 1.76 & 1.94 & 0.68 \\
\hline As & $<1$ & $<1$ & $<1$ & $<1$ & 1 & n.d. & 1 & 1 & & & \\
\hline $\mathrm{Ga}$ & 19 & 20 & 18 & 18 & 21 & 22 & 19 & 20 & 18 & 13 & 17 \\
\hline $\mathrm{Zn}$ & 52 & 48 & 37 & 13 & 68 & 45 & 43 & 75 & 23 & 25 & 22 \\
\hline $\mathrm{Cu}$ & $<1$ & 4 & 4 & $<1$ & 8 & 5 & $<1$ & 17 & 8 & $<2$ & 8 \\
\hline Mo & $<1$ & $<1$ & $<1$ & $<1$ & $<1$ & n.d. & $<1$ & $<1$ & & & \\
\hline $\mathrm{Ni}$ & 68 & 20 & 8 & 5 & 13 & 4 & 72 & 25 & 5 & $<2$ & 6 \\
\hline $\mathrm{Ba}$ & 241 & 326 & 399 & 108 & 319 & 312 & 205 & 448 & 682 & 150 & 662 \\
\hline $\mathrm{V}$ & 28 & 48 & 32 & 12 & 73 & 76 & 37 & 128 & 16 & 16 & 10 \\
\hline $\mathrm{Cr}$ & 38 & 31 & 13 & 8 & 18 & 41 & 41 & 34 & 12 & 15 & 16 \\
\hline $\mathrm{Pb}$ & 5 & 5 & 10 & 3 & 33 & 3 & 6 & 13 & 35 & 10 & 28 \\
\hline $\mathrm{Th}$ & 2 & $<1$ & $<1$ & $<1$ & 4 & 4 & $<1$ & $<1$ & 38 & 7 & 27 \\
\hline $\mathrm{Rb}$ & 175 & 220 & 257 & 32 & 115 & 134 & 201 & 95 & 245 & 66 & 261 \\
\hline $\mathrm{U}$ & 1 & $<1$ & $<1$ & $<1$ & 1 & 1 & $<1$ & $<1$ & 11 & 7 & 12 \\
\hline $\mathrm{Sr}$ & 478 & 430 & 472 & 551 & 490 & 335 & 482 & 390 & 123 & 41 & 136 \\
\hline $\mathrm{Y}$ & 10 & 11 & 8 & 2 & 20 & 27 & 8 & 20 & 105 & 39 & 59 \\
\hline $\mathrm{Zr}$ & 41 & 31 & 29 & 10 & 67 & 70 & 27 & 112 & 221 & 250 & 369 \\
\hline $\mathrm{Nb}$ & $<1$ & $<1$ & $<1$ & $<1$ & $<1$ & 3 & $<1$ & 7 & 28 & 8 & 22 \\
\hline \multicolumn{12}{|l|}{$\mathrm{Sn}$} \\
\hline $\mathrm{F}$ & 454 & 777 & & $<20$ & 984 & & 776 & & & & \\
\hline $\mathrm{La}$ & 5.8 & 4.5 & & 2.1 & 9.4 & & 4 & & & & \\
\hline $\mathrm{Ce}$ & 13.6 & 13.5 & & 4.3 & 22 & & 8.9 & & & & \\
\hline $\operatorname{Pr}$ & 1.8 & 1.8 & & 0.5 & 3.1 & & 1.2 & & & & \\
\hline $\mathrm{Nd}$ & 8.2 & 8 & & 2.4 & 14.8 & & 5.4 & & & & \\
\hline $\mathrm{Sm}$ & 2 & 1.8 & & 0.5 & 3.8 & & 1.4 & & & & \\
\hline $\mathrm{Eu}$ & 1.19 & 1.28 & & 0.67 & 2.18 & & 0.9 & & & & \\
\hline $\mathrm{Gd}$ & 2.2 & 1.9 & & 0.5 & 4.2 & & 1.5 & & & & \\
\hline $\mathrm{Tb}$ & 0.3 & 0.3 & & 0.1 & 0.6 & & 0.2 & & & & \\
\hline Dy & 2 & 1.8 & & 0.4 & 3.6 & & 1.5 & & & & \\
\hline Ho & 0.38 & 0.33 & & 0.08 & 0.7 & & 0.26 & & & & \\
\hline $\mathrm{Er}$ & 1.1 & 0.9 & & 0.2 & 2 & & 0.8 & & & & \\
\hline $\mathrm{Tm}$ & 0.2 & 0.1 & & $<0.2$ & 0.3 & & 0.1 & & & & \\
\hline $\mathrm{Yb}$ & 1.1 & 1 & & 0.2 & 1.8 & & 0.8 & & & & \\
\hline $\mathrm{Lu}$ & 0.14 & 0.12 & & $<0.05$ & 0.25 & & 0.1 & & & & \\
\hline
\end{tabular}



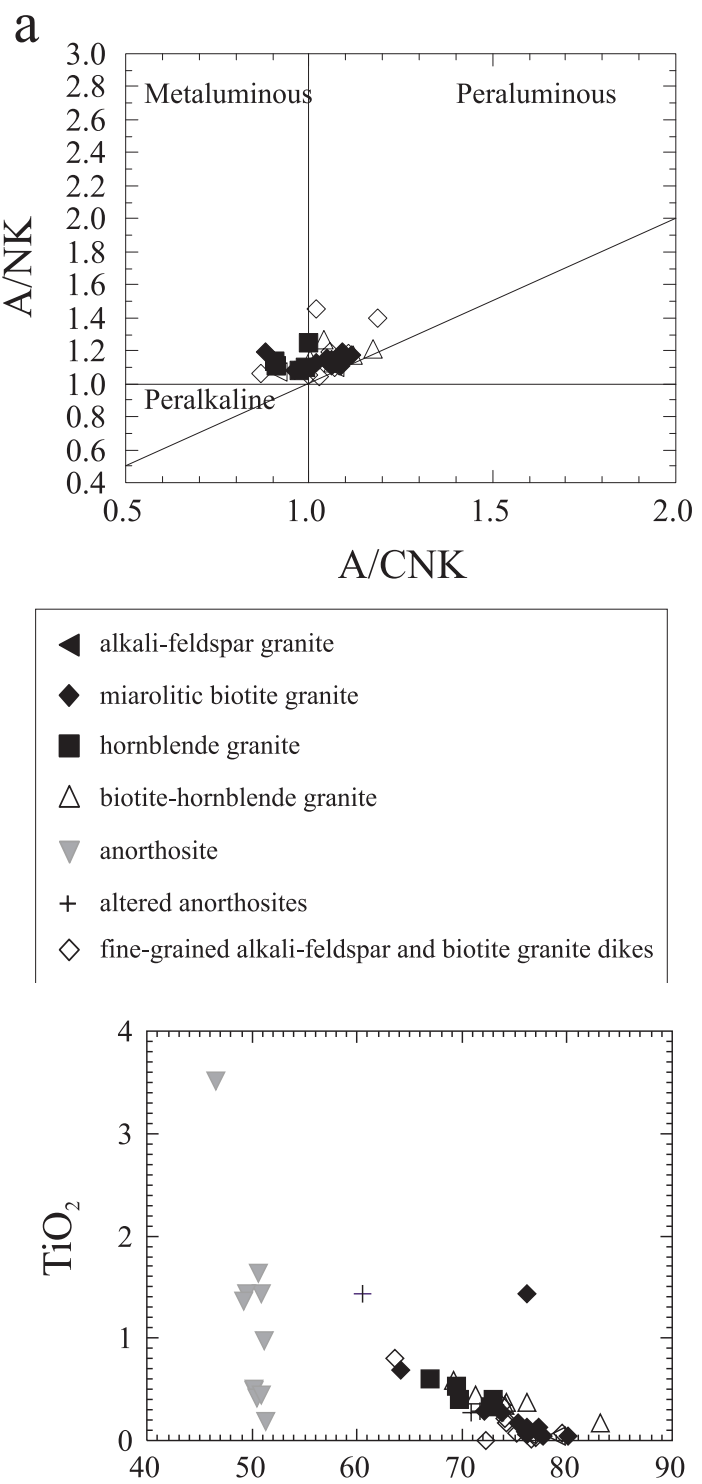

$\mathrm{SiO}_{2}$

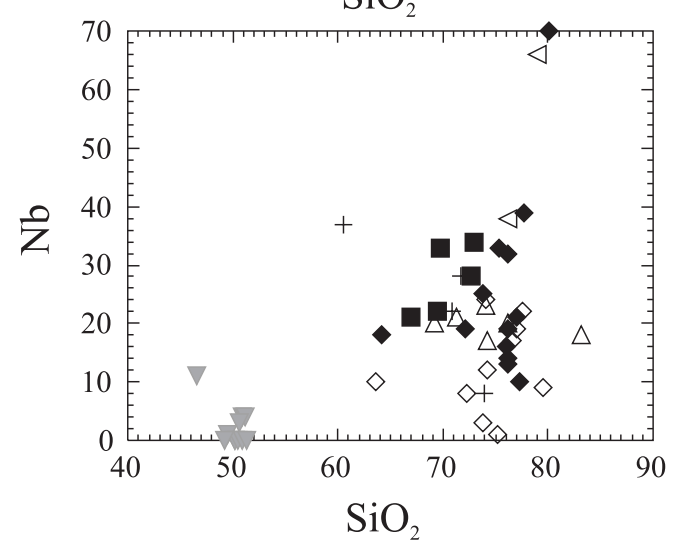

b

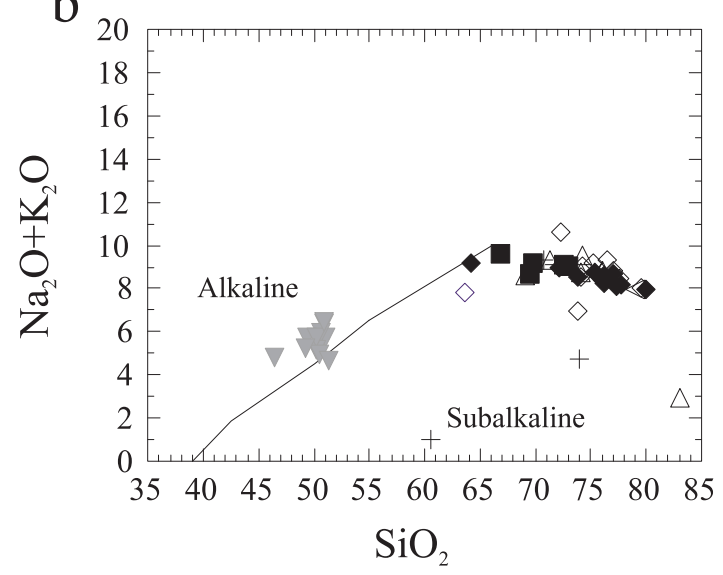

Fig. 10. The Redrock Granite, the anorthosites, and the fine-grained alkali feldspar and biotite granite dikes in (a) $\mathrm{A} / \mathrm{NK}$ vs. $\mathrm{A} / \mathrm{CNK}$, and (b) $\mathrm{K}_{2} \mathrm{O}+\mathrm{Na}_{2} \mathrm{O}$ vs. $\mathrm{SiO}_{2}$ diagrams. The line separating the alkaline and subalkaline fields in (b) is from Irvine and Baragar (1971).

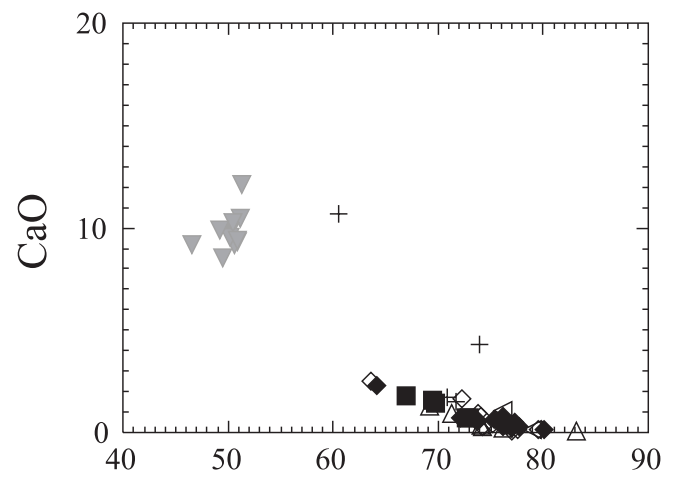

$\mathrm{SiO}_{2}$

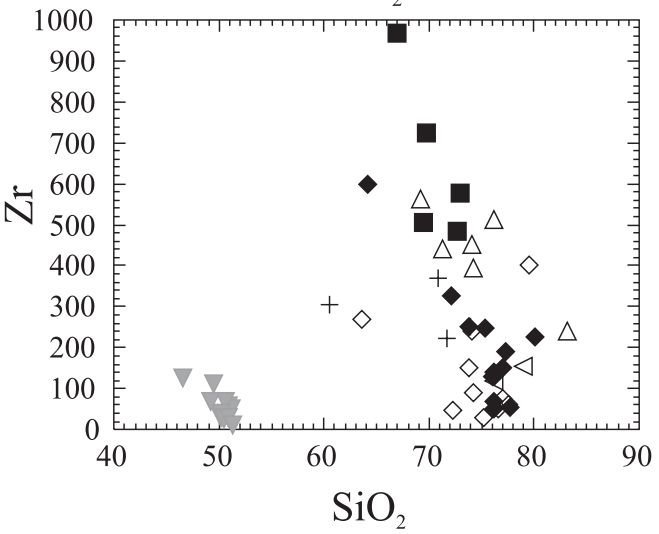

Fig. 11. Harker-variation diagrams for selected major (wt. \%) and trace element (ppm) compositions of the Redrock Granite, the anorthosites, and the fine-grained alkali feldspar and biotite granite dikes. Symbols as in Figure 10. 
a

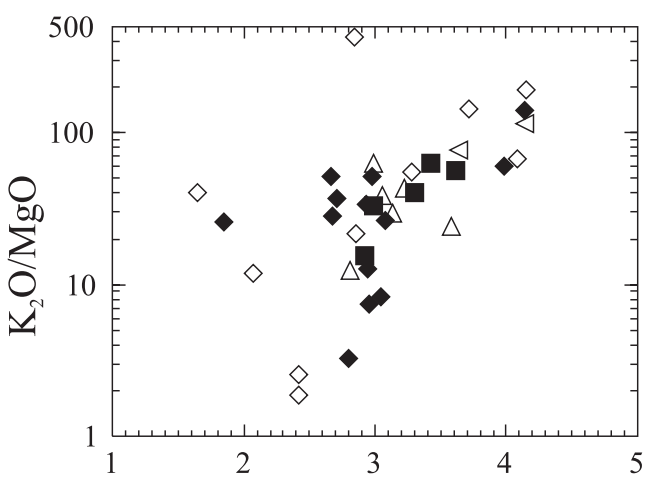

C

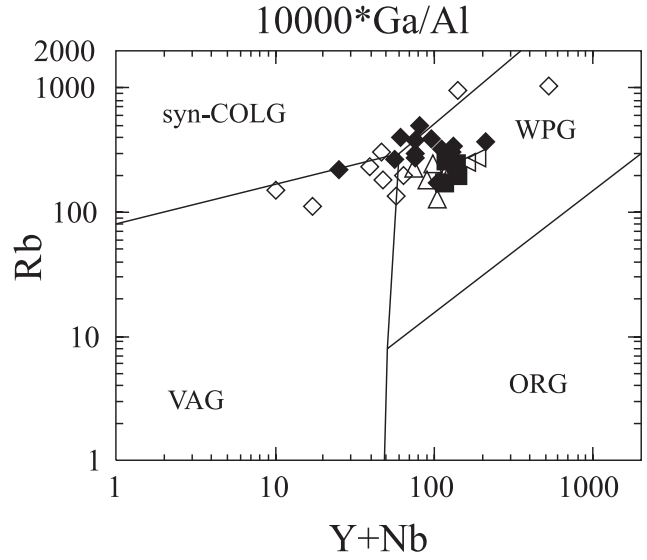

1000
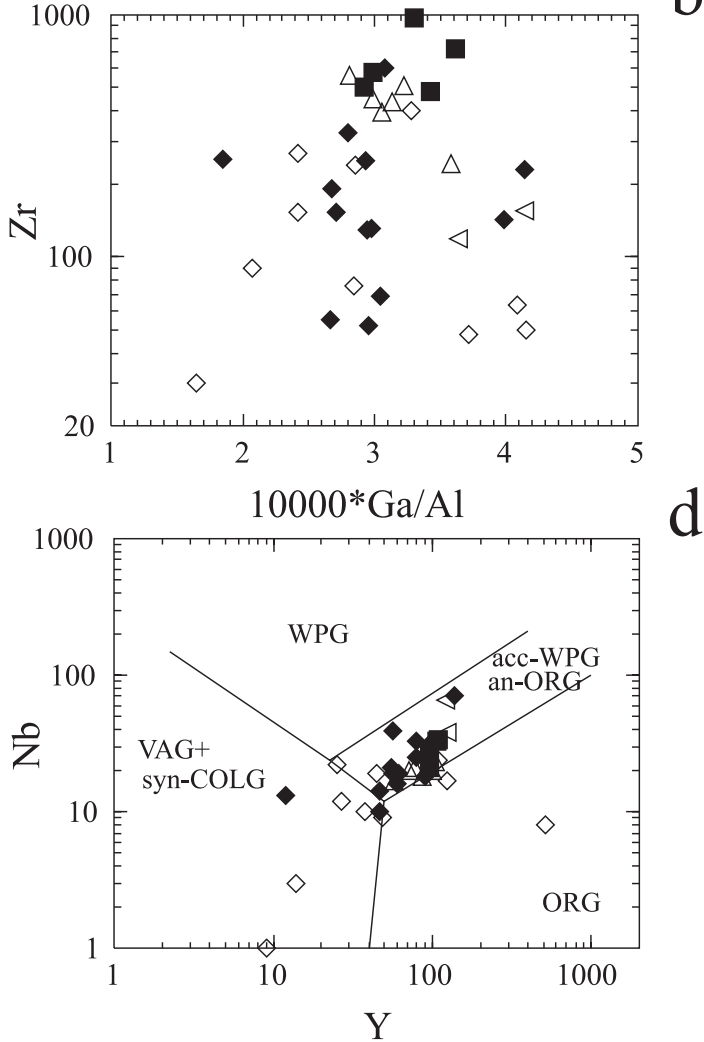

b

Fig. 12. The Redrock Granite and the fine-grained alkali feldspar and biotite granite dikes plotted in (a) $\mathrm{K}_{2} \mathrm{O} /$ $\mathrm{MgO}$ vs. $10000^{*} \mathrm{Ga} / \mathrm{Al}$ and (b) $\mathrm{Zr}$ vs. $10000^{*} \mathrm{Ga} / \mathrm{Al}$ discrimination diagrams of Whalen et al. (1987), and (c) Rb vs. $\mathrm{Y}+\mathrm{Nb}$ and (d) Nb vs. Y tectonic discrimination diagrams of Pearce et al. (1984). WPG -within-plate granites, acc-WPG-attenuated continental crust within-plate granites, VAG-volcanic arc granites, syn-COLG-syncollision granites, ORG-ocean ridge granites, and an-ORG -anomalous ocean ridge granites. Symbols as in Figure 10.

a

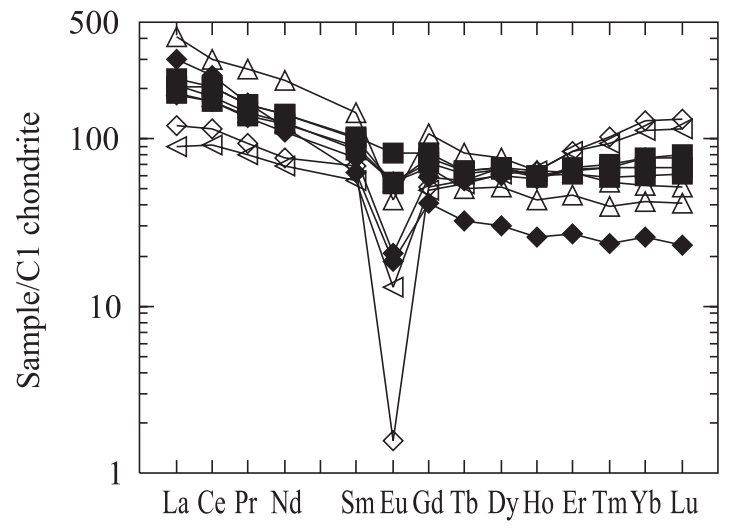

b

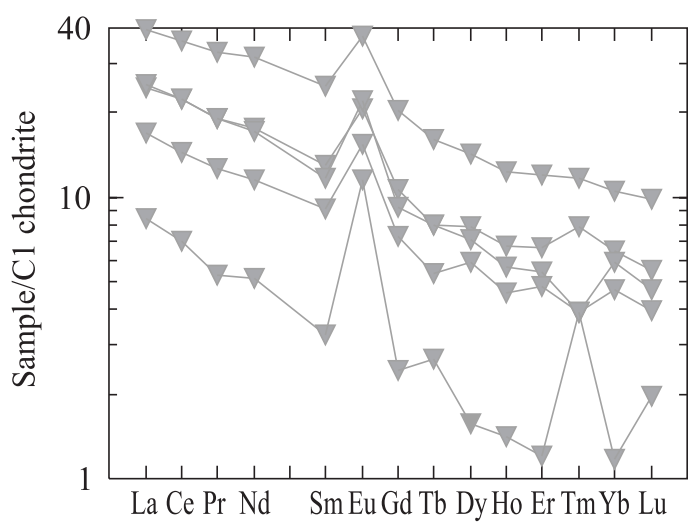

Fig. 13. The chondrite-normalized REE contents of (a) the Redrock Granite and the fine-grained alkali feldspar and biotite granite dikes and $(b)$ the anorthosites. Symbols as in Figure 10. 
Al-discrimination diagrams, the Redrock Granite shows distinctive A-type characteristics, and plots in the within-plate granite (WPG) field in the tectonic discrimination diagrams (Fig. 12).

All four phases of the Redrock Granite show relatively flat chondrite-normalized patterns for the rare earth elements (Fig. 13). The patterns of the biotite-hornblende, hornblende, and miarolitic biotite granite phases are slightly LREE-enriched $\left([\mathrm{La} / \mathrm{Yb}]_{\mathrm{N}}\right.$ from 2.25 to 10.95$)$, whereas the alkali feldspar granite is slightly enriched in HREE $\left([\mathrm{La} / \mathrm{Yb}]_{\mathrm{N}} 0.75\right)$. The negative Eu-anomaly becomes gradually more pronounced from the hornblende granite $\left([\mathrm{Eu} / \mathrm{Eu} *]_{\mathrm{N}} 0.89\right)$ to the alkali feldspar granite $\left([\mathrm{Eu} / \mathrm{Eu} *]_{\mathrm{N}} 0.25\right)$. This is consistent with a typical magmatic evolutional sequence.

\section{Fine-grained alkali feldspar and biotite granite dikes}

The chemical compositions of the alkali feldspar and biotite granite dikes are variable but grossly similar to the miarolitic biotite granite phase of the Redrock Granite (Figs. 10-12). They are metaluminous to peraluminous and marginally alkaline to subalkaline (Fig. 10). The dikes have $\mathrm{Rb} / \mathrm{Sr}>1$, $\mathrm{K}_{2} \mathrm{O} / \mathrm{Na}_{2} \mathrm{O}>1, \mathrm{Nb}>5 \mathrm{ppm}, \mathrm{V}<25 \mathrm{ppm}$, and $\mathrm{Cr}<100$ ppm, typical of A-type granites and the Finnish rapakivi granites (Whalen et al. 1987, Eby 1990, Rämö 1991). The geochemical scatter in many of the dikes is consistent with late-stage, volatile-rich fluids typical of granitic dikes. The negative $\mathrm{Eu}-$ anomaly is more pronounced in the dike samples compared to the Redrock Granite (Fig. 13).

\section{ISOTOPE GEOCHEMISTRY}

In order to put constraints on the petrogenesis and geochronology of the Redrock Granite and associated rocks, $\mathrm{Nd}, \mathrm{Sr}$, and $\mathrm{Ar}$ isotopic compositions of samples of the Redrock Granite, the anorthosites, and their immediate metamorphic country rocks were determined (Tables 7, 8; Figs. $14,15)$. The ${ }^{40} \mathrm{Ar} /{ }^{39} \mathrm{Ar}$ data are summarized in McLemore et al. (2000a, b), and a summary is in Table 8.

The four granites analyzed for $\mathrm{Nd}$ and $\mathrm{Sr}$ isotopic compositions comprise a hornblende granite (NM 19-98), biotite-hornblende granite (NM 61-98), alkali feldspar granite (NM 76-98), and miarolitic biotite granite (NM 106-98; Table 7). The samples from the anorthosite xenoliths in the miarolitic biotite granite (RED 4, RED 7, RED 11,

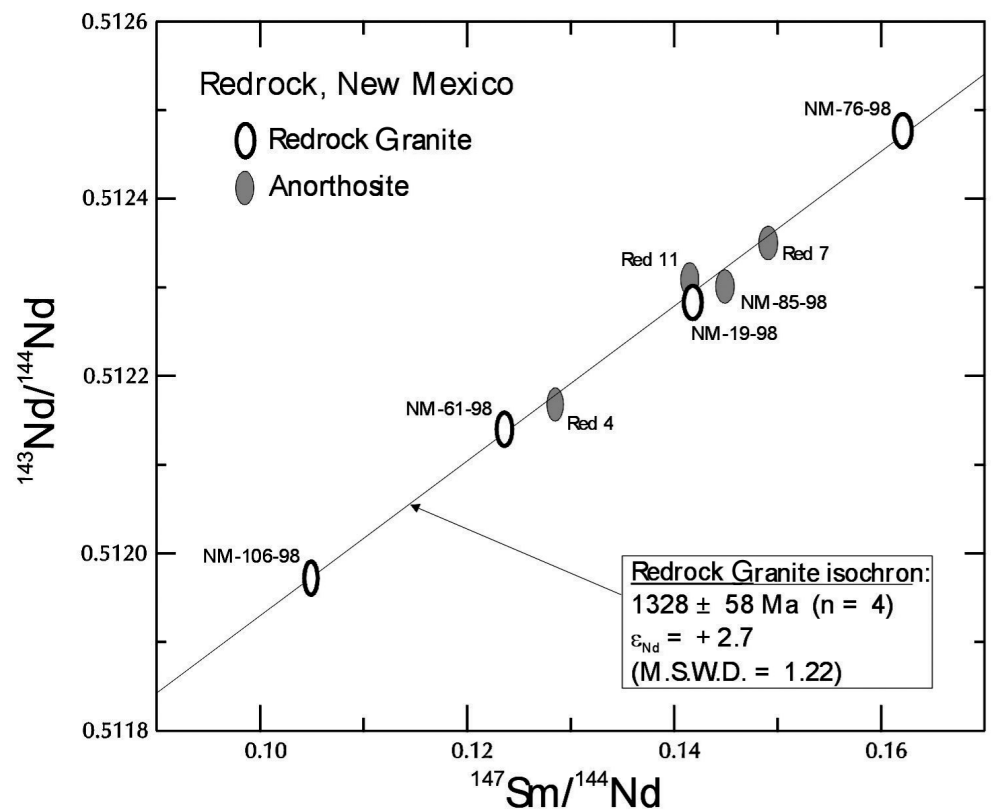

Fig. 14. Sm-Nd isochron diagram of the Redrock Granite and the associated anorthosites. The size of the symbol represents the $2 \sigma$ error on the variables. 


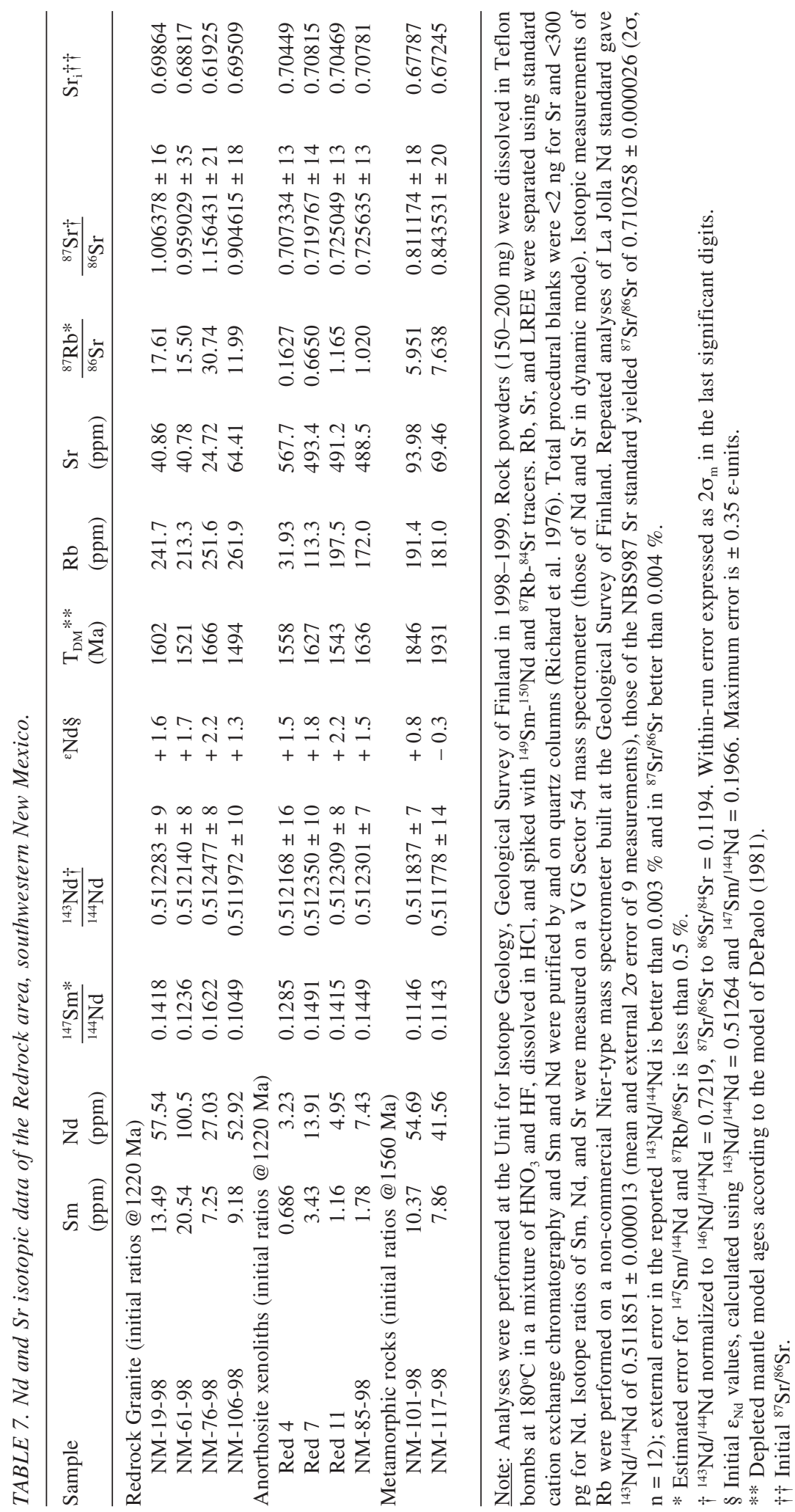


NM 85-98) represent different types of coarsegrained to very coarse-grained anorthosite and leucogabbro. A quartzo-feldspathic gneiss (NM 10198) and a metasediment (NM 117-98), both from the Ash Creek series of Hewitt (1959), were analyzed and represent the metamorphic country rocks on the eastern flank of the Redrock Granite.

\section{$\mathrm{Nd}$ isotopes}

The four Redrock Granite samples show a wide range in their $\mathrm{Sm}$ and $\mathrm{Nd}$ concentrations (7.3 to $20.5 \mathrm{ppm} \mathrm{Sm}$ and 27.0 to $100.5 \mathrm{ppm} \mathrm{Nd}$ ) and ${ }^{147} \mathrm{Sm} /{ }^{144} \mathrm{Nd}(0.1049$ to 0.1622$)$. In the $\mathrm{Sm}-\mathrm{Nd}$ isochron diagram (Fig. 14), they fall on an isochron with an age of $1328 \pm 58 \mathrm{Ma}$, initial $\varepsilon_{\mathrm{Nd}}$ value of +2.7 , and MSWD (Mean Square of Weighted Deviates-goodness of fit indicator) of 1.22. This shows that, even though the granitic samples come from distinct lithologic units, they probably represent a single batch of silicic magma that underwent substantial differentiation. The isochron age is somewhat higher than what is indicated by preliminary ion probe $\mathrm{U}-\mathrm{Pb}$ determinations (M. Hamilton, personal communication, 2001) and ${ }^{40} \mathrm{Ar} /$

${ }^{39} \mathrm{Ar}$ mineral ages. The $\varepsilon_{\mathrm{Nd}}$ values calculated at
$1220 \mathrm{Ma}$ for the individual samples range from +1.3 to +2.2 and are thus almost identical within the experimental error of \pm 0.35 e-units. The depleted mantle model ages (DePaolo 1981) of the granites range from 1494 to $1666 \mathrm{Ma}$, reflecting the large range in the $\mathrm{Sm}-\mathrm{Nd}$ ratios.

The $\mathrm{Sm}-\mathrm{Nd}$ data of the extensively altered anorthosites is more difficult to interpret with certainty. The four samples analyzed from the anorthositic xenoliths have much lower Sm (0.7 to $3.4 \mathrm{ppm}$ ) and $\mathrm{Nd}$ (3.2 to $13.9 \mathrm{ppm}$ ) concentrations than the granites and ${ }^{147} \mathrm{Sm} /{ }^{144} \mathrm{Nd}$ that span a smaller range (0.1285 to 0.1491$)$; these values are, however, typical of massif-type anorthosites associated with rapakivi granites (e.g., Rämö 1991). In the $\mathrm{Sm}-\mathrm{Nd}$ isochron diagram (Fig. 14) they plot roughly along the Redrock Granite isochron. If a regression line is calculated for these samples, it corresponds to an age of $1326 \pm 830 \mathrm{Ma}$, initial $\varepsilon_{\mathrm{Nd}}$ value of +2.6 , and MSWD of 5.6. The initial $\varepsilon_{\mathrm{Nd}}$ (at $1220 \mathrm{Ma}$ ) values of the four anorthosite samples range from +1.5 to +2.2 and the model ages are between 1543 and $1636 \mathrm{Ma}$. These data suggest that the isotopic system of the anorthosites could represent a magmatic system that was roughly coeval with the Redrock Granite.

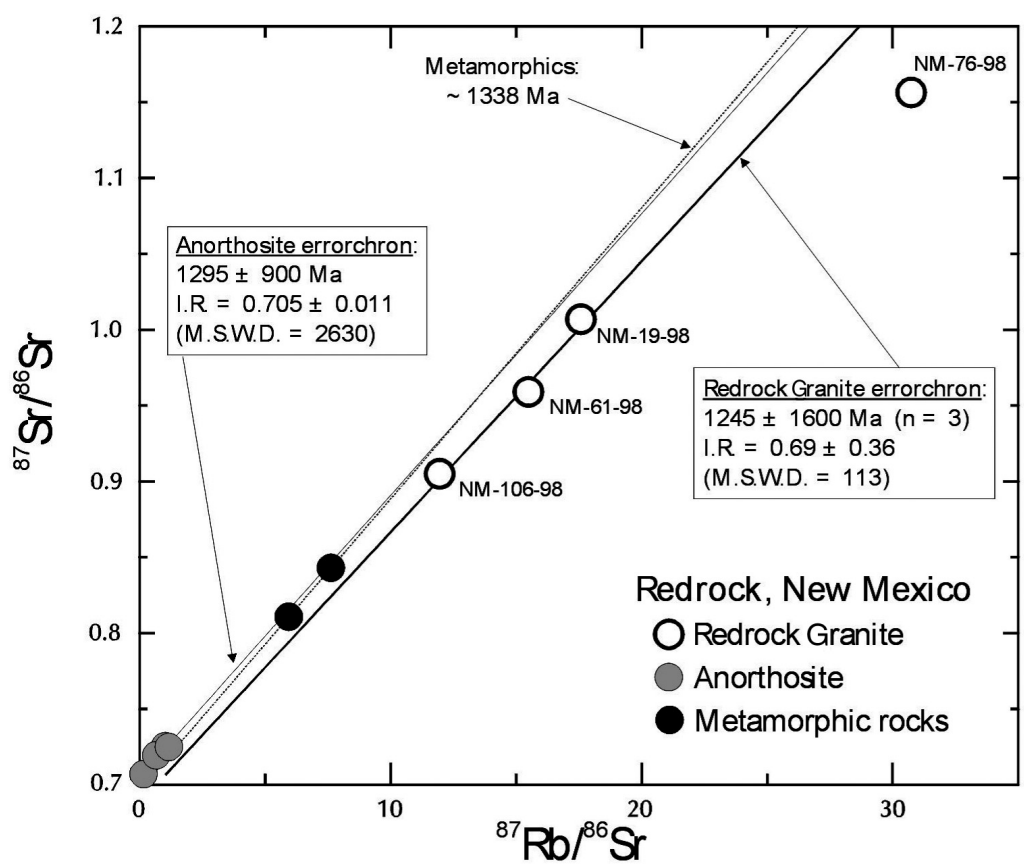

Fig. 15. Rb-Sr isochron diagram of the Redrock Granite, the associated anorthosites, and metamorphic country rocks. 
TABLE 8. Summary of age determinations.

\begin{tabular}{|c|c|c|c|}
\hline Sample & ${ }^{40} \mathrm{Ar} /{ }^{39} \mathrm{Ar}(\mathrm{Ma})$ (mineral dated) & $\mathrm{Rb} / \mathrm{Sr}$ whole rock (Ma) & $\mathrm{U} / \mathrm{Pb}$ isochron $(\mathrm{Ma})$ \\
\hline Gabbro/diabase/d & & & \\
\hline NM118-98 & $* \sim 1000$ (hornblende) & & \\
\hline \multicolumn{4}{|c|}{ Rhyodacite-dacite porphyry dikes } \\
\hline NM1G & * 1200 (hornblende) & & \\
\hline \multicolumn{4}{|c|}{$\begin{array}{l}\text { Fine-grained biotite granite dike } \\
\text { (related to Redrock Granite) }\end{array}$} \\
\hline NM84-98 & $1206 \pm 15$ (biotite) & & \\
\hline Redrock Granite & & $\sim 1250$ & \\
\hline NM19-98 & * 1200 (hornblende) & & $1220 \pm 5$ (zircon) \\
\hline NM93-98 & $\begin{array}{c}1210 \pm 5 \text { (hornblende) } \\
1205 \pm 12 \text { (biotite) }\end{array}$ & & \\
\hline NM279-99 & $* \sim 1200$ (biotite) & & \\
\hline \multicolumn{4}{|l|}{ Anorthosite } \\
\hline Red7A & $1228.5 \pm 4.5$ (hornblende) & & $1230 \pm 4$ (zircon) \\
\hline Red7B & $1216.9 \pm 5.3$ (hornblende) & & \\
\hline NM312 & & & $1223 \pm 6$ (zircon) \\
\hline
\end{tabular}

* disturbed age spectrum. ${ }^{40} \mathrm{Ar} /{ }^{39} \mathrm{Ar}$ ages from McLemore et al. (2000b) and unpublished data (Rämö et al., in preparation). $\mathrm{U} / \mathrm{Pb}$ ages from unpublished data.

The two analyzed metamorphic rocks have similar, crustal-type ${ }^{147} \mathrm{Sm} /{ }^{144} \mathrm{Nd}(0.1143$ and 0.1146 ; e.g. Rämö \& Calzia 1998) and distinctly less radiogenic ${ }^{143} \mathrm{Nd} /{ }^{144} \mathrm{Nd}$ compared to those of the granites and anorthosite xenoliths (Table 7). They have initial $\varepsilon_{\mathrm{Nd}}$ (at $1560 \mathrm{Ma}$ ) values of -0.3 and +0.8 and model ages of 1846 and $1931 \mathrm{Ma}$.

\section{Sr isotopes}

The $\mathrm{Rb}-\mathrm{Sr}$ isotopic systematics of the Redrock Granite samples is characterized by very high ${ }^{87} \mathrm{Rb} /{ }^{86} \mathrm{Sr}$ (12 to 31 ) and ${ }^{87} \mathrm{Sr} /{ }^{86} \mathrm{Sr}$ (0.90 to 1.16$)$. In the $\mathrm{Rb}-\mathrm{Sr}$ isochron diagram (Fig. 15), three of the granites (NM 19-98, NM 61-98, NM 106-98) plot on a trend conforming to an age of $\sim 1250 \mathrm{Ma}$. The fit of this trend is, however, very poor (MSWD of 113) and precludes calculation of a meaningful initial ratio. The alkali feldspar granite (NM 76-98) falls grossly off the trend defined by the three other samples. The initial ratios of the individual samples are less than 0.7 at $1220 \mathrm{Ma}$ (Table 7) and suggest that the $\mathrm{Rb}-\mathrm{Sr}$ systematics of the samples have been disturbed since the crystallization of the Redrock Granite.
The anorthosite xenoliths have much lower ${ }^{87} \mathrm{Rb} /{ }^{86} \mathrm{Sr}$ and ${ }^{87} \mathrm{Sr} /{ }^{86} \mathrm{Sr}$ than the granites and, in the $\mathrm{Rb}-\mathrm{Sr}$ isochron diagram (Fig. 15), fall close to origin. The samples show considerable scatter and fall on a poorly defined trend with an age of $\sim 1300$ Ma. Again, because of the considerable scatter of the data points, the trend does not yield a meaningful initial ratio. However, the initial ${ }^{87} \mathrm{Sr} /{ }^{86} \mathrm{Sr}$ of the least radiogenic sample (RED 4) is 0.70449 at $1220 \mathrm{Ma}$ and may represent a close estimate of the initial ratio of the anorthosites.

The two metamorphic country rocks are somewhat less radiogenic than the miarolitic biotite granite (Table 7). In the $\mathrm{Rb}-\mathrm{Sr}$ isochron diagram (Fig. 15), they fall on a line that corresponds to an age of $\sim 1340 \mathrm{Ma}$. The initial ${ }^{87} \mathrm{Sr} /{ }^{86} \mathrm{Sr}$ are less than 0.7 at $1560 \mathrm{Ma}$ and, again, show that the RbSr systematics of these samples have been affected by later disturbance.

\section{${ }^{40} \mathrm{Ar} /{ }^{39} \mathrm{Ar}$ isotopes}

Several micas and amphiboles from the major rock units in the study area were dated by the ${ }^{40} \mathrm{Ar} /{ }^{39} \mathrm{Ar}$ age-spectrum method (Table 1, 8; McLemore et 


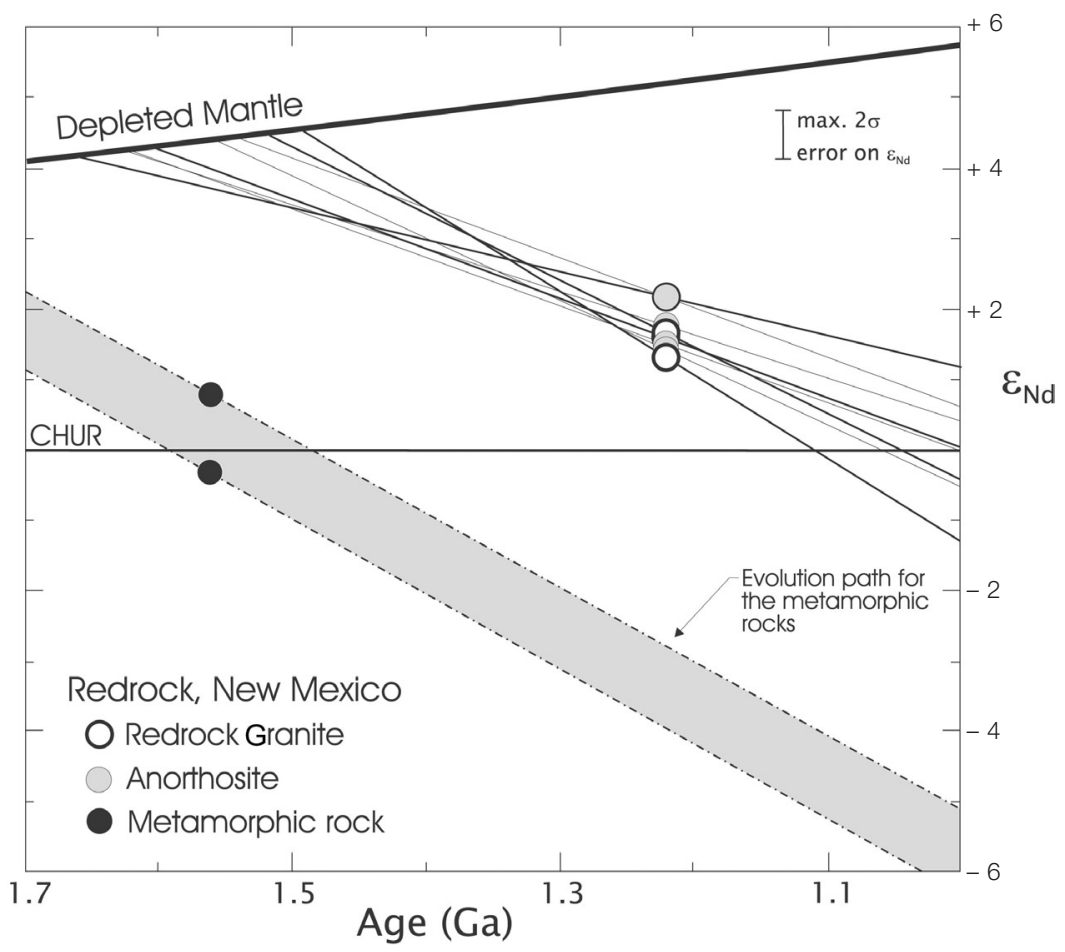

Fig. 16. $\varepsilon_{N d}$ vs. age diagram showing the initial Nd isotopic composition of the Redrock Granite, the associated anorthosites, and metamorphic country rocks. Evolution lines for individual samples are indicated. Also shown is the evolution of depleted mantle (DePaolo 1981) and undifferentiated Earth (CHUR; DePaolo \& Wasserburg 1976).

al. 2000b). All of the mineral ages in the immediate vicinity of the Redrock Granite cluster at $\sim 1200 \mathrm{Ma}$, which was interpreted as a thermal event by McLemore et al. (2000a, b). The minerals that yield $\sim 1200 \mathrm{Ma}$ argon ages generally yield well-behaved age spectra that are characterized by significant flat segments with typical $2 \sigma$ uncertainties of $\sim 5$ to $15 \mathrm{Ma}$ (Table 8 ). Two lines of evidence support a $\sim 1220 \mathrm{Ma}$ intrusion age for the Redrock Granite. The regional mica apparent ages are $\sim 1400$ Ma (Table 1; McLemore et al. 2000b; unpublished data) and thus indicate that the ambient temperature near the Redrock Granite was less than $300^{\circ} \mathrm{C}$, and the concordance of mica and amphibole dates at 1200 Ma requires rapid cooling. The $\sim 1220 \mathrm{Ma}$ intrusion age is consistent with preliminary ion probe data on zircons (Rämö et al., in preparation). Argon mineral ages of $\sim 1200$ Ma are uncommon for New Mexico and the southwestern United States in general (Adams \& Keller 1996, Karlstrom et al. 1997). However, the Burro Mountains falls along the trend of 1100 1200 Ma magmatism described by Bickford et al. (2000).

\section{Discussion of isotopic data}

The initial Nd isotopic composition of the Redrock samples is shown in an $\varepsilon_{\mathrm{Nd}}$ vs. age diagram in Figure 16. The initial ratios of the granites and anorthosite xenoliths are practically identical and fall between the depleted mantle evolution curve and the CHUR line at $1220 \mathrm{Ma}$. This shows that their source was characterized by moderate longterm depletion of LREE. In many Proterozoic Atype granite-anorthosite associations, the initial ratios of the granitic and mafic rocks are quite similar and have been ascribed to the mafic, mantlederived rocks as having assimilated $\mathrm{Nd}$ from a crustal source that also acted as a protolith for the granitic rocks (Rämö \& Haapala 1995).

The Nd isotopic composition of the metamorphic rocks is drastically different from that of the granites and anorthosites (Fig. 16). At $1220 \mathrm{Ma}$, the $\varepsilon_{\mathrm{Nd}}$ values of the metamorphic rocks are on the order of -3 to -4 and show that the granites could not have been derived from a crustal source with this Nd isotopic composition; a more juvenile protolith is required. This could have been a lower 
crust domain that was formed from the $\sim 1650 \mathrm{Ma}$ crust by hybridization caused by mafic underplating slightly prior to the generation of the Redrock Granite and anorthosites. It should also be noted that the Nd model ages of the two metamorphic rocks (1896 and $1931 \mathrm{Ma}$ ) are clearly older than those reported for the $\mathrm{Nd}$ province 3 of the western United States (Bennett \& DePaolo 1987). This suggests that the Burro Mountains terrane comprises a more complex crust than previous models suggest (Bennett \& DePaolo 1987).

\section{CONCLUDING REMARKS}

The available data indicate that the $\sim 1220 \mathrm{Ma}$ Redrock Granite (McLemore et al. 2000a, b) is metaluminous to peraluminous, marginally alkaline to subalkaline and was emplaced at a relatively high level in the crust as evidenced by the miarolitic cavities, hydrothermal alteration, and ${ }^{40} \mathrm{Ar} /$ ${ }^{39} \mathrm{Ar}$ cooling ages. Mineral chemistry evaluations suggest, however, that much of the granite is unaltered, and bulk geochemical analyses should yield near-primary compositions. The Redrock Granite shows the geochemical features typical of A-type granites (Fig. 12; Whalen et al. 1987), including a high iron content of unaltered amphiboles and biotites. The mineral and whole rock chemistries of the Redrock Granite are similar to those of the A-type granites in the subsurface of west Texas and eastern New Mexico (Barnes et al. 1999) and the Red Bluff Granite in west Texas (Shannon et al. 1997). The A-type character of the Redrock Granite suggests emplacement in an extensional setting, which is consistent with the tentative correlation of the serpentine-carbonate rocks at Redrock to the Castner Marble that was deposited in a rift basin at $\sim 1260$ Ma (Pittenger et al. 1994, Bickford et al. 2000).

Field relationships, whole rock and mineral geochemical and isotopic trends suggest that the four phases of the Redrock Granite are related, with the miarolitic biotite/alkali feldspar granite being the youngest phase. The presence of two micas, garnet, and monazite in the miarolitic biotite granite suggests that it is the most evolved of the granite phases. If only the $\mathrm{Nd}$ isotopic data are examined, one might conclude that the four phases of the Redrock Granite are part of a single zoned pluton. However, the brecciated contact relationships and mineralogical data indicate that the Redrock Granite was emplaced as at least two separate intrusions, the hornblende granite/biotite-hornblende granite and the miarolitic biotite granite/alkali feldspar granite (Fig. 2), which were probably derived from essentially the same magma source.

Bickford et al. (2000), among others, have proposed that $\sim 1250$ Ma rift basins may have formed along the southern margin of Laurentia during the Grenville orogeny. Rocks that range in age from 1000 to1260 Ma are found throughout southwestern Laurentia in present United States and Mexico (Larson et al. 1994, Bickford et al. 2000). The Llano uplift of Texas records $\sim 1326-1275 \mathrm{Ma}$ island-arc accretion and magmatism, followed by deposition in a continental rift from $\sim 1250$ to 1260 Ma (Roback 1996, Mosher 1998, Bickford et al. 2000). Evidence of rifting is also found in the Franklin Mountains with the deposition of the Castner Marble at $\sim 1260$ Ma (Pittenger et al. 1994). Bimodal magmatic activity and additional rift sedimentation was widespread in west Texas, southern New Mexico, Arizona, and California from $\sim 1190$ to $1000 \mathrm{Ma}$ (Larson et al. 1994, Smith et al. 1997, Bickford et al. 2000). For instance, the Hazel Formation in the Llano uplift and the Red Bluff Granite and Thunderbird Group in the Franklin Mountains, west Texas were emplaced at $\sim 1120$ Ma (Shannon et al. 1997, Bickford et al. 2000). Alkaline syenite, granite, and gabbroic rocks in the Pajarito Mountain in south-central New Mexico were emplaced at $\sim 1150-1190 \mathrm{Ma}$ (Kelly 1968, Moore et al. 1988). The Cardenas Basalt in the Grand Canyon, Arizona was emplaced at $\sim 1100 \mathrm{Ma}$ (Larson et al. 1994) and the Unkar Group, also in the Grand Canyon, records deposition in rift basins between 1200 and 1100 Ma (Timmons et al. 2001). Alkaline, transitional, and tholeiitic diabase sills and dikes were emplaced in the Death Valley area at $\sim 1100 \mathrm{Ma}$ (Heamon \& Grotzinger 1992). Arc magmatism was still active in eastern Mexico from 1230 to $1150 \mathrm{Ma}$ as evidenced by the Huiznopala Gneiss and gra- 
nitic cobbles in a Paleozoic conglomerate (Lawlor et al. 1999, Lopez et al. 2001), and was followed by emplacement of an anorthosite-gabbro complex at $\sim 1000 \mathrm{Ma}$, which could represent similar extension as found in southwestern United States. The $\sim 1220$ Ma Redrock Granite falls directly within this trend. Geochemical and isotopic data indicate that the Redrock Granite represents the early stages of the 1000-1260 Ma magmatism and associated extension along the southwestern boundary of Laurentia, well inboard of the contemporaneous collision (Grenville) boundary farther to the southeast. Collectively, these data indicate that the southern margin of Laurentia has a prolonged history of multiple episodes of extension from 1000 to $1260 \mathrm{Ma}$ (Timmons et al. 2001).

The isotopic data and the spatial association of the anorthosite xenoliths and the Redrock Granite strongly suggest that the granite and the anorthosites are of a similar age and genetically related, even though the anorthosites are extensively altered. The anorthosite xenoliths could represent the crustal rocks beneath the exposed Redrock Granite that were caught up in the granitic magma chamber, or they could represent roof pendants from the rocks that the Redrock Granite intruded, and which have since been eroded. Available geophysical data are inadequate to provide details of the crust underlying the Redrock Granite. In most granite-anorthosite complexes worldwide, granites are found to cut the spatially associated anorthosites (Ashwal 1993), similar to the relationships found at Redrock. Nd isotopic data suggest that the anorthosite xenoliths could be coeval with the Redrock Granite.

These relationships are consistent with the anorthosites being derived from the upper mantle, possibly as deep mantle upwellings, and the granite from the lower crust in a rift setting. The process involved melting in the upper mantle, emplacement of anorthosite in the crust resulting in partial melting and thinning of the crust, and, finally, intrusion of shallow silicic plutons (Anderson \& Bender 1989, Emslie 1991, Haapala \& Rämö 1992, Rämö \& Haapala 1995). The high crystallization temperature required to produce the Redrock Granite from partial melting of the low- er crust is reflected in the fluid-poor nature (low LOI, rarity of pegmatites) and chemical characteristics (high $\mathrm{P}_{2} \mathrm{O}_{5}$ and $\mathrm{Zr}$, Emslie 1991) of the Redrock Granite. The relatively fluid-rich miarolitic biotite granite (compared to the other phases of the Redrock Granite) with associated pegmatites is evidence of a late, fluid-saturation stage of multiple granitic intrusions and was accompanied by magmatic-hydrothermal alteration.

Geochemical and isotopic data suggest that the Redrock Granite/anorthosites and the metamorphic rocks were derived from distinctly different protoliths. The Redrock Granite and the anorthosites were presumably derived from sources characterized by subtle, long-term LREE depletion. These sources were clearly more juvenile ( $\mathrm{Nd}$ model ages $\sim 1600 \mathrm{Ma}$ ) in nature than the metamorphic rocks of the region ( $\mathrm{Nd}$ model ages $\sim 1900 \mathrm{Ma}$ ) and may have included a significant Middle Proterozoic mafic lower crust/subcontinental lithospheric mantle component. Finally, the Nd model ages of the metamorphic rocks ( 1900 Ma) suggest that the crust underlying the Burro Mountains is more complex than originally thought (cf. Bennett \& DePaolo 1987, Karlstrom \& Bowring 1988, Karlstrom \& Humphreys 1998).

ACKNOWLEDGMENTS. This report is part of ongoing studies of Proterozoic igneous rocks in the Burro Mountains in southwestern New Mexico, supported by the NMBGMR (NMIMT, Peter Scholle, Director and State Geologist), the University of Helsinki, Finland and the Academy of Finland (projects \#36002, 44145). Special thanks to Chris Ortega, Don Graves, and Alton Ford of the New Mexico Game and Fish Department who allowed access into the Redrock Wildlife Refuge; this area is restricted and permission must be obtained before entering. We would like to thank $M$. C. Gilbert and M. Barnes for reviewing an earlier version of this manuscript; their comments are appreciated. Phil Kyle and Chris McKee (NMBGMR) analyzed samples by $X$-ray-fluorescence (XRF) using the Philips PW 2400 instrument purchased with funds from NSF grant EAR-9316467. Lynn Brandvold (NMBGMR) analyzed samples for $\mathrm{FeO} / \mathrm{Fe}_{2} \mathrm{O}_{3}$ by titration methods. The Cameca SX- 
100 electron microprobe at NMIMT was partially funded by NSF Grant STI-9413900. Lisa Peters and Rich Esser carried out the mineral separations and ${ }^{40} \mathrm{Ar} /{ }^{\beta 9} \mathrm{Ar}$ age determinations at the New Mexico Geochronology Laboratory at NMIMT. Lynn Heizler assisted with the electron microprobe analyses. The fourth author acknowledges assistance from the staff of the Unit for Isotope Geology, Geological Survey of Finland, Tuula Hokkanen and Arto Pulkkinen in particular, for the Nd and Sr isotopic analyses. James McLemore and Peter Rinkleff assisted with fieldwork and Peter Rinkleff, Kelley Donahue, Doug Jones, Robert Thompson, and Erik Munroe assisted with sample preparation. Kelley Donahue also provided additional technical assistance. Discussions with Karl Karlstrom, Kent Condie, Nancy McMillan, David Hedlund, James Rattè, and William McIntosh were beneficial and helpful in understanding the regional geology.

\section{REFERENCES}

Adams, D.C.\& Keller, G.R. 1994. Possible extension of the Midcontinent Rift in west Texas and eastern New Mexico. Canadian Journal of Earth Sciences 31, 709-720.

Adams, D.C. \& Keller, G.R. 1996. Precambrian basement geology of the Permian Basin region of West Texas and eastern New Mexico: A geophysical perspective. American Association of Petroleum Geologists, Bulletin 80, 410-431.

Anderson, J.L. 1983. Proterozoic anorogenic granite plutonism of North America. In: Medaris, L.G. Jr., Byers, C.W., Milkelson, D.M., Shanks, W.C. (eds.) Proterozoic geology. Geological Society of America, Memoir 161, $133-154$.

Anderson, J.L. \& Bender, E. 1989. Nature and origin of Proterozoic A-type granitic magmatism in the southwestern United States of America. Lithos 23, 19-52.

Ashwal, L.D. 1993. Anorthosites. In: Minerals and Rocks 21. Springer-Verlag, Berlin. 422 p.

Ashwal, L.D. \& Burke, K. 1987. Types and characteristics of terrestrial anorthosite. In: Lunar and Planetary Science meeting XVIII. Lunar and Planetary Science Institute, Houston, Texas, 34-35.

Barbarin, B. 1996. Genesis of the two main types of peraluminous granitoids. Geology 24, 295-298.

Barnes, M.A., Rohs, C.R., Anthony, E.Y., van Schmus, W.R. \& Denison, R.E. 1999. Isotopic and elemental chemistry of subsurface Precambrian igneous rocks, west Texas and eastern New Mexico. Rocky Mountain Geology 34, 245-262.
Bennett, V.C. \& DePaolo, D.J. 1987. Proterozoic crustal history of the western United States as determined by neodymium isotopic mapping. Geological Society of America, Bulletin 99, 674-685.

Bickford, M.E., Soegaard, K., Nielson, K.C. \& McLelland, J.M. 2000. Geology and geochronology of Grenville-age rocks in the Van Horn and Franklin Mountains area, west Texas: Implications for tectonic evolution of Laurentia during the Grenville. Geological Society of America, Bulletin 112, 1134-1148.

Coney, P.J. 1978. The plate tectonic setting of southeastern Arizona. New Mexico Geological Society, Guidebook 29, 285-290.

De la Roche, H., Leterrier, J., Granclaude, P. \& Marchal, M. 1980. A classification of volcanic and plutonic rocks using R1-R2 diagrams and major element analyses -its relationships and current nomenclature. Chemical Geology 29, 183-210.

DePaolo, D.J. 1981. Neodymium isotopes in the Colorado Front Range and crust-mantle evolution in the Proterozoic. Nature 291, 193-196.

DePaolo, D.J. \& Wasserburg, G.J. 1976. Nd isotopic variations and petrogenetic models. Geophysical Research Letters 3, 249-252.

Drewes, H. 1991. Description and development of the Cordilleran orogenic belt in the southwestern United States. U.S. Geological Survey, Professional Paper 1512. 92 p.

Drewes, H., Houser, B.B., Hedlund, D.C. Richter, D.H., Thorman, C.H. \& Finnell, T.L. 1985. Geologic map of the Silver City 1 degree x 2 degree quadrangle, New Mexico and Arizona. U.S. Geological Survey, Map I1310C, 1:250,000.

Easton, R.M. 1990. Meta-anorthosites in the Grenville Province of Ontario. In: Gower, C. F., Rivers, T. \& Ryan, B. (eds.) Mid-Proterozoic Laurentia-Baltica. Geological Association of Canada, Special Paper 39, 387397.

Eby, G.N. 1990. The A-type granitoids: A review of their occurrence and chemical characteristics and speculation on their petrogenesis. Lithos 26, 115-134.

Elliott, B.A. 2001. Crystallization conditions of the Wiborg rapakivi batholith, SE Finland: an evaluation of amphibole and biotite mineral chemistry. Mineralogy and Petrology 72, 305-324.

Emslie, R.F. 1991. Granitoids of rapakivi graniteanorthosite and related associations. Precambrian Research 51, 173-192.

Finnell, T.L. 1987. Geologic map of the Cliff quadrangle, Grant County, New Mexico. U.S. Geological Survey, Miscellaneous Geologic Investigations Map I-1768, 1:50,000.

Haapala, I., McLemore, V., Rämö, O.T. \& Kosunen, P. 2000. Epidote-chlorite alteration of a Mesoproterozoic miarolitic granite from the Burro Mountains, New Mexico. $31^{\text {st }}$ International Geological Congress, Abstract Volume (CD- ROM).

Haapala, I. \& Rämö, O.T. 1990. Petrogenesis of the Proterozoic rapakivi granites of Finland. In: Stein, H.J. \& Hannah, J.L. (eds.) Ore-bearing granite systems: Petro- 
genesis and mineralizing processes. Geological Society of America, Special Paper 246, 275-286.

Haapala, I. \& Rämö, O.T. 1992. Tectonic setting and origin of the Proterozoic rapakivi granites of southern Fennoscandia. Transactions of the Royal Society of Edinburgh: Earth Sciences 83, 165-171.

Heaman, L.M. \& Grotzinger, J.P. 1992. 1.08 Ga diabase sills in the Pahrump Group, California: implications for development of the Cordilleran miogeocline. Geology 20, 637-640.

Hedlund, D.C. 1980a. Geologic map of the Redrock NW quadrangle, Grant County, New Mexico. U.S. Geological Survey, Miscellaneous Field Studies Map MF-1263, $1: 24,000$.

Hedlund, D.C. 1980b. Geologic map of the Redrock NE quadrangle, Grant County, New Mexico. U.S. Geological Survey, Miscellaneous Field Studies Map MF-1264, $1: 24,000$.

Hewitt, C.H. 1959. Geology and mineral deposits of the northern Big Burro Mountains - Redrock area, Grant County, New Mexico. New Mexico Bureau of Mines and Mineral Resources, Bulletin 60. 151 p.

Irvine, T.N. \& Baragar, W.R.A. 1971. A guide to the chemical classification of the common volcanic rocks. Canadian Journal of Earth Sciences 8, 523-548.

Karlstrom, K.E., Åhäll, K.I., Harlan, S.S., Williams, M.L., McLelland, J. \& Geissman, J.W. 2001. Long-lived (1.8$1.0 \mathrm{Ga}$ ) convergent orogeny in southern Laurentia, its extensions to Australia and Baltica, and implications for refining Rodinia. Precambrian Research 111, 5-30.

Karlstrom, K.E. \& Bowring, S.A. 1988. Early Proterozoic assembly of tectonostratigraphic terranes in southwestern North America. Journal of Geology 96, 561-576.

Karlstrom, K.E. \& Bowring, S.A. 1993. Proterozoic orogenic history of Arizona. In: Reed, J.C. Jr., Bickford, M.E., Houston, R.S., Link, P.K., Rankin, D.W., Sims, P.K. \& van Schmus, W.R. (eds.) Precambrian: Conterminous U. S. Geological Society of America, The Geology of North America C-2, 188-211.

Karlstrom, K.E., Doe, M.F., Wessels, R.L., Bowring, S.A., Donn, J.C. \& Williams, M.L. 1990. Juxtaposition of Proterozoic crustal blocks: 1.65-1.60 Ga Mazatzal orogeny. Arizona Geological Survey, Special Paper 7, 114 123.

Karlstrom, K.E., Dallmeyer, R.D. \& Grambling, J.A. 1997. ${ }^{40} \mathrm{Ar} /{ }^{39} \mathrm{Ar}$ evidence for $1.4 \mathrm{Ga}$ regional metamorphism in New Mexico: implications for thermal evolution of lithosphere in the southwestern USA. Journal of Geology $105,205-223$.

Karlstrom, K.E. \& Humphreys, E.D. 1998. Persistent influence of Proterozoic accretionary boundaries in the tectonic evolution of southwestern North America: Interaction of cratonic grain and mantle modification events. Rocky Mountain Geology 33, 161-179.

Kelly, V.C. 1968. Geology of the alkali Precambrian rocks at Pajarito Mountain, Otero County, New Mexico. Geological Society of America, Bulletin 79, 1565-1572.

Kosunen, P.J., Rämö, O.T., McLemore, V.T., McKee, C. \& Haapala, I. 1999. Lamprophyric (minette) magmatism and Proterozoic rapakivi granites: Preliminary observations from the Redrock area, Burro Mountains, New Mexico. Geological Society of America, Abstracts with Programs 31, A261.

Larson, E.E., Patterson, P.E. \& Mutschler, F.E. 1994. Lithology, chemistry, age, and origin of the Proterozoic Cardenas Basalt, Grand Canyon, Arizona. Precambrian Research 65, 255-276.

Lawlor, P.J., Ortega-Gutièrrez, F., Cameron, K.L., OchoaCamarillo, H., Lopez, R. \& Sampson, D.E. 1999. U-Pb geochronology, geochemistry, and provenance of the Grenvillian Huiznopala Gneiss of eastern Mexico. Precambrian Research 94, 73-99.

Leake, B.E. 1978. Nomenclature of amphiboles. Canadian Mineralogist 16, 501-520.

Leake, B.E. and others 1997. Nomenclature of amphiboles: report of the Subcommittee on Amphiboles of the International Mineralogical Association, commission on new minerals and mineral names. Canadian Mineralogist 35, 219-246.

Lopez, R., Cameron, K.L. \& Jones, N.W. 2001. Evidence for Paleoproterozoic, Grenvillian, and Pan-African age Gondwanan crust beneath northeastern Mexico. Precambrian Research 107, 195-214.

McIntosh, W.C., Kedzie, L.L. \& Sutter, J.F. 1991. Paleomagnetic and ${ }^{40} \mathrm{Ar} /{ }^{39} \mathrm{Ar}$ dating database for MogollonDatil ignimbrites, southwestern New Mexico. New Mexico Bureau of Mines and Mineral Resources, Bulletin 135. $79 \mathrm{p}$.

McLemore, V.T. 2000. Geology and mineral resources of the Wild Horse Mesa area, Burro Mountains, Grant County, New Mexico. In: Lawton, T.F., McMillan, N.J., McLemore, V.T., Austin, G. \& Barker, J.M. (eds.) Southwest Passage, A Trip through the Phanerozoic. New Mexico Geological Society Guidebook 51, 245-252.

McLemore, V.T., Heizler, M.T., Rämö, T. \& Kosunen, P.J. 2000a. Significance of the 1200 Ma Redrock granite, Burro Mountains, New Mexico. Geological Society of America, Abstracts with Programs 32, A317.

McLemore, V.T. \& McKee, C. 1988a. A preliminary geochemical study of the Redrock anorthosite and granite, Burro Mountains, southwestern New Mexico. In: Mack, G. H., Lawton, T. F. \& Lucas, S. G. (eds.) Cretaceous and Laramide evolution of southwestern New Mexico. New Mexico Geological Society, Guidebook 39, 83-88.

McLemore, V.T. \& McKee, C. 1988b. Geochemistry of the Burro Mountains syenites and adjacent Proterozoic granite and gneiss and the relationship to a Cambrian-Ordovician alkalic magmatic event in New Mexico and southern Colorado. In Mack, G.H., Lawton, T.F. \& Lucas, S.G. (eds.) Cretaceous and Laramide evolution of southwestern New Mexico. New Mexico Geological Society, Guidebook 39, 89-98.

McLemore, V.T., McMillan, N.J., Heizler, M. \& McKee, C. 1999a. Cambrian alkaline rocks at Lobo Hill, Torrance County, New Mexico: More evidence for a Cambrian-Ordovician aulacogen. In: Pazzaglia, F., Lucas, S. G. \& Austin, G. S. (eds.) Albuquerque Country III. New Mexico Geological Society, Guidebook 50, 247-253. 
McLemore, V.T., Rämö, O.T., Kosunen, P.J., Haapala, I., Heizler, M. \& McKee, C. 2000b. Geology and geochemistry of Proterozoic granitic and mafic rocks in the Redrock area, northern Burro Mountains, Grant County, New Mexico; A Progress Report. In: Lawton, T.F., McMillan, N.J., McLemore, V.T., Austin, G. \& Barker, J.M. (eds.) Southwest Passage, A Trip through the Phanerozoic. New Mexico Geological Society, Guidebook 51, 117-126.

McLemore, V.T., Rämö, O.T., McKee, C., Heizler, M., Haapala, I. \& Kosunen, P.J. 1999b. Origin of the Redrock anorthosite and rapakivi granite (Proterozoic), Redrock, New Mexico: Preliminary Observations. Geological Society of America, South-Central Section Meeting, Abstracts with programs 31, A29.

McMillan, N.J., McLemore, V.T. \& Ervin, S. D. 2000. Cambrian tectonics of New Mexico and Colorado. In: Lawton, T.F., McMillan, N.J., McLemore, V.T., Austin, G. \& Barker, J.M. (eds.) Southwest Passage, A Trip through the Phanerozoic. New Mexico Geological Society, Guidebook 51, 37-39.

Moore, S.L., Foord, E.E. \& Meyer, G.A. 1988. Geologic and aeromagnetic map of a part of the Mescalero Apache Indian Reservation, Otero County, New Mexico. U.S. Geological Survey, Miscellaneous Investigations Map I1775, 1:50,000.

Mosher, S. 1998. Tectonic evolution of the southern Laurentian Grenville orogenic belt. Geological Society of America, Bulletin 110, 1357-1375.

Pearce, J.A., Harris, N.B. W. \& Tindle, A.G. 1984. Trace element discrimination diagrams for the tectonic interpretation of granitic rocks. Journal of Petrology 24, 956983.

Pittenger, M.A., Marsaglia, K.M. \& Bickford, M.E. 1994. Depositional history of the middle Proterozoic Castner Marble and basal Mundy Breccia, Franklin Mountains, West Texas. Journal of Sedimentary Research 64B, 282297.

Rämö, O.T. 1991. Petrogenesis of the Proterozoic rapakivi granites and the related basic rocks of southeastern Fennoscandia: $\mathrm{Nd}$ and $\mathrm{Pb}$ isotopic and general geochemical constraints. Geological Survey of Finland, Bulletin 335. $161 \mathrm{p}$.

Rämö, O.T. \& Calzia, J.P. 1998. Nd isotopic composition of cratonic rocks in the southern Death Valley region: Evidence for a substantial Archean source component in Mojavia. Geology 26, 891-894.

Rämö, O.T. \& Haapala, I. 1995. One hundred years of rapakivi granite. Mineralogy and Petrology 52, 129-185.

Rämö, O.,T., McLemore, V.T., Kosunen, P.J., Haapala, I., McKee, C. \& Heizler, M. 1999. Nd Isotopic assessment of the Proterozoic granitoid and associated mafic rocks of the Redrock area, Burro Mountains, New Mexico. Geological Society of America, Abstracts with programs 31, A260.

Reese, J.F, Mosher, S., Connelly, J. \& Roback, R. 2000. Mesoproterozoic chronostratigraphy of the southeastern Llano uplift, central Texas. Geological Society of America, Bulletin 112, 278-291.
Richard, P., Shimizu, N. \& Allègre C.J. $1976 .{ }^{143} \mathrm{Nd} /{ }^{144} \mathrm{Nd}$, a natural tracer: An application to oceanic basalts. Earth and Planetary Science Letters 31, 269-278.

Richardson, J. M., Bell, K., Watkinson, D. H. \& Blenkinsop, J. 1990. Genesis and fluid evolution of the East Kemptville greisen-hosted tin mine, southwestern Nova Scotia, Canada. In: Stein, H.J. \& Hannah, J.L. (eds.) Ore-bearing granite systems: Petrogenesis and mineralizing processes. Geological Society of America, Special Paper 246, 181-203.

Roback, R.C. 1996. Characterization and tectonic evolution of a Mesoproterozoic island arc in the southern Grenville orogen, Llano uplift, central Texas. Tectonophysics 265, 29-52.

Ross, C.A. \& Ross, J.R.P. 1986. Paleozoic paleotectonics and sedimentation in Arizona and New Mexico. In: Peterson, J. A. (ed.) Paleotectonics and sedimentation in the Rocky Mountain Region, United States. American Association of Petroleum Geologists, Memoir 41, 653668.

Roycroft, P. 1991. Magmatically zoned muscovite from the peraluminous two-mica granites of the Leinster batholith, southeast Ireland. Geology 19, 437-440.

Shannon, W.M., Barnes, C.G. \& Bickford, M.E. 1997. Grenville magmatism in west Texas: Petrology and geochemistry of the Red Bluff granitic suite. Journal of Petrology 38, 1279-1305.

Simmons, E.C. \& Hanson, G.N. 1978. Geochemistry and origin of massif-type anorthosites. Contributions to Mineralogy and Petrology 66, 119-135.

Smith, D.R., Barnes, C., Shannon, W., Roback, R. \& James, E. 1997. Petrogenesis of Mid-Proterozoic granitic magmas: examples from central and west Texas. Precambrian Research 85, 53-79.

Stacey, J.S. \& Hedlund, D.C. 1983. Lead-isotopic compositions of diverse igneous rocks and ore deposits from southwestern New Mexico and their implications for early Proterozoic crustal evolution in western United States. Geological Society of America, Bulletin 94, 4357.

Timmons, J.M., Karlstrom, K.E., Dehler, C.M., Geissman, J.W. \& Heizler, M.T. 2001. Proterozoic multistage (ca. 1.1 and $0.8 \mathrm{Ga}$ ) extension recorded in the Grand Canyon Supergroup and establishment of northwest- and north-trending tectonic grains in the southwestern United States. Geological Society of America, Bulletin 113, 163-180.

Wahl, D.E. 1980. Mid-Tertiary volcanic geology in parts of Greenlee County, Arizona and Grant County, New Mexico. Ph.D. dissertation, Tucson, Arizona State University. $144 \mathrm{p}$.

Whalen, J.B., Currie, K.L. \& Chappell, B.W. 1987. A-type granites: geochemical characteristics, discrimination and petrogenesis. Contributions to Mineralogy and Petrology 95, 407-419. 
APPENDIX 1. Location of samples.

\begin{tabular}{|c|c|c|c|}
\hline Sample number & Latitude ${ }^{\circ} \mathrm{N}$ & Longitude ${ }^{\circ} \mathrm{W}$ & Lithology \\
\hline NM 20-98 & 32.74517 & 108.71958 & fine-grained biotite and $\mathrm{K}$-feldspar granite dike \\
\hline NM 22-98 & 32.74472 & 108.69817 & fine-grained biotite and $\mathrm{K}$-feldspar granite dike \\
\hline NM 49-98 & 32.74794 & 108.66361 & fine-grained biotite and $\mathrm{K}$-feldspar granite dike \\
\hline NM 79-98 & 32.74961 & 108.711 & fine-grained biotite and $\mathrm{K}$-feldspar granite dike \\
\hline NM 84-98 & 32.74842 & 108.70831 & fine-grained biotite and $\mathrm{K}$-feldspar granite dike \\
\hline NM 94-98 & 32.74783 & 108.70911 & fine-grained biotite and $\mathrm{K}$-feldspar granite dike \\
\hline NM 95-98 & 32.74872 & 108.70567 & fine-grained biotite and $\mathrm{K}$-feldspar granite dike \\
\hline NM161-99 & 32.729887 & 108.679274 & fine-grained biotite and $\mathrm{K}$-feldspar granite dike \\
\hline NM235-99 & 32.76567 & 108.6295 & fine-grained biotite and $\mathrm{K}$-feldspar granite dike \\
\hline B16.1R & 32.747832 & 108.708386 & Redrock granite-miarolitic biotite granite \\
\hline B16.2R & 32.747680 & 108.712615 & Redrock granite-miarolitic biotite granite \\
\hline B9.1 & 32.751887 & 108.705510 & Redrock granite-miarolitic biotite granite \\
\hline B9.8 & 32.751885 & 108.705510 & Redrock granite-miarolitic biotite granite \\
\hline B9.9 & 32.751883 & 108.705510 & Redrock granite-miarolitic biotite granite \\
\hline Red 3 & 32.753004 & 108.703964 & Redrock granite-miarolitic biotite granite \\
\hline Red 5 & 32.753525 & 108.707364 & Redrock granite-miarolitic biotite granite \\
\hline Red 6 & 32.754391 & 108.707125 & Redrock granite-miarolitic biotite granite \\
\hline Red 10 & 32.750821 & 108.712308 & Redrock granite-miarolitic biotite granite \\
\hline NM4-96 & 32.753250 & 108.709863 & Redrock granite-miarolitic biotite granite \\
\hline NM 8-96 & 32.75292 & 108.7095 & Redrock granite-miarolitic biotite granite \\
\hline NM 11-96 & 32.74958 & 108.71747 & Redrock granite-miarolitic biotite granite \\
\hline Red 9 & 32.751390 & 108.713377 & Redrock granite-alkali feldspar granite \\
\hline NM 77-98 & 32.74853 & 108.71933 & Redrock granite-miarolitic biotite granite \\
\hline NM 106-98 & 32.74639 & 108.71739 & Redrock granite-miarolitic biotite granite \\
\hline NM 76-98 & 32.74775 & 108.7185 & Redrock granite-alkali feldspar granite \\
\hline NM 1-96 & 32.754408 & 108.708100 & Redrock granite-hornblende granite \\
\hline NM 19-98 & 32.74833 & 108.72169 & Redrock granite-hornblende granite \\
\hline NM 131-98 & 32.74561 & 108.71189 & Redrock granite-hornblende granite \\
\hline NM 314-99 & 32.748385 & 108.698567 & Redrock granite-hornblende granite \\
\hline Red 14 & 32.751002 & 108.719725 & Redrock granite-hornblende granite \\
\hline NM 61-98 & 32.7503 & 108.72603 & Redrock granite-coarse-grained biotite-hornblende granite \\
\hline NM 93-98 & 32.74719 & 108.70847 & Redrock granite-coarse-grained biotite-hornblende granite \\
\hline NM279-99 & 32.76042 & 108.73414 & Redrock granite-coarse-grained biotite-hornblende granite \\
\hline NM279A-99 & 32.76042 & 108.73414 & Redrock granite-coarse-grained biotite-hornblende granite \\
\hline NM281-99 & 32.76047 & 108.73931 & Redrock granite-coarse-grained biotite-hornblende granite \\
\hline B9.2 & 32.751656 & 108.705407 & anorthosite/leucogabbro \\
\hline B9.4 & 32.751658 & 108.705407 & anorthosite/leucogabbro \\
\hline B9.5 & 32.751659 & 108.705407 & anorthosite/leucogabbro \\
\hline RED 1 & 32.752127 & 108.706099 & anorthosite/leucogabbro \\
\hline RED 2 & 32.752619 & 108.705437 & anorthosite/leucogabbro \\
\hline RED 4 & 32.75401 & 108.70119 & anorthosite/leucogabbro \\
\hline RED 7 & 32.749 & 108.71712 & anorthosite/leucogabbro \\
\hline RED 11 & 32.7492 & 108.71874 & anorthosite/leucogabbro \\
\hline NM-3-98 & 32.752712 & 108.708035 & anorthosite/leucogabbro \\
\hline NM 85-98 & 32.74883 & 108.70831 & anorthosite/leucogabbro \\
\hline NM312-99 & 32.75235 & 108.70062 & anorthosite/leucogabbro \\
\hline B9.6 & 32.751659 & 108.705407 & anorthosite/leucogabbro \\
\hline B9.7 & 32.751659 & 108.705407 & anorthosite/leucogabbro \\
\hline B9.3 & 32.751656 & 108.705407 & anorthosite/leucogabbro \\
\hline NM 101-98 & 32.74086 & 108.70075 & metamorphic rocks \\
\hline NM 117-98 & 32.73914 & 108.71342 & metamorphic rocks \\
\hline
\end{tabular}


APPENDIX 2. Alkali feldspar analyses of the Redrock Granite and the anorthosites.

\begin{tabular}{|c|c|c|c|c|c|c|c|c|c|c|c|c|}
\hline & \multicolumn{12}{|c|}{ Miarolitic biotite granite } \\
\hline & NM11 & NM11 & NM11 & NM11 & NM11 & NM11 & NM11 & NM11 & NM11 & NM11 & NM11 & NM11 \\
\hline & $-\mathrm{n} 1$ & $-\mathrm{n} 2$ & $-\mathrm{n} 18$ & $-\mathrm{n} 19$ & -10 & -12 & -13 & -14 & -19 & -20 & -23 & -24 \\
\hline$\overline{\mathrm{SiO}_{2}}$ & 61.43 & 64.44 & 64.50 & 64.31 & 64.83 & 64.35 & 64.61 & 64.19 & 64.37 & 64.41 & 64.50 & 64.62 \\
\hline $\mathrm{Al}_{2} \mathrm{O}_{3}$ & 17.99 & 18.90 & 19.02 & 18.88 & 18.92 & 18.89 & 19.00 & 18.83 & 18.89 & 18.89 & 18.76 & 18.90 \\
\hline $\mathrm{CaO}$ & 2.23 & 0.01 & 0.02 & 0.00 & 0.02 & 0.02 & 0.01 & 0.00 & 0.02 & 0.00 & 0.00 & 0.01 \\
\hline $\mathrm{FeO}$ & 0.07 & 0.00 & 0.05 & 0.30 & 0.03 & 0.07 & 0.10 & 0.08 & 0.00 & 0.04 & 0.07 & 0.03 \\
\hline $\mathrm{SrO}$ & 0.01 & 0.00 & 0.01 & 0.02 & 0.01 & 0.02 & 0.02 & 0.02 & 0.00 & 0.00 & 0.00 & 0.01 \\
\hline $\mathrm{BaO}$ & 0.02 & 0.04 & 0.00 & 0.00 & 0.00 & 0.02 & 0.03 & 0.05 & 0.01 & 0.04 & 0.01 & 0.00 \\
\hline $\mathrm{Na}_{2} \mathrm{O}$ & 0.28 & 0.34 & 0.33 & 0.26 & 0.66 & 0.36 & 0.46 & 0.30 & 0.04 & 0.03 & 0.40 & 0.36 \\
\hline $\mathrm{K}_{2} \mathrm{O}$ & 16.22 & 16.89 & 16.84 & 16.66 & 16.34 & 16.97 & 16.61 & 16.72 & 16.87 & 16.82 & 16.70 & 16.71 \\
\hline Total & 98.25 & 100.62 & 100.77 & 100.43 & 100.80 & 100.69 & 100.83 & 100.18 & 100.21 & 100.24 & 100.42 & 100.63 \\
\hline $\mathrm{Ab}$ & 2.3 & 96.9 & 89.4 & 97.7 & 5.8 & 3.1 & 4 & 2.6 & 0.3 & 0.3 & 3.5 & 3.2 \\
\hline An & 10.1 & 2.8 & 9.9 & 2.1 & 0.1 & 0.1 & 0.1 & 0 & 0.1 & 0.2 & 0 & 0 \\
\hline Or & 87.6 & 0.3 & 0.6 & 0.3 & 94.1 & 96.8 & 95.9 & 97.4 & 99.6 & 99.5 & 96.5 & 96.8 \\
\hline
\end{tabular}

\begin{tabular}{|c|c|c|c|c|c|c|c|c|c|c|c|c|}
\hline \multicolumn{13}{|c|}{ Redrock Granite- biotite-hornblende granite } \\
\hline & $\begin{array}{r}\text { NM93- } \\
98-15\end{array}$ & $\begin{array}{r}\text { NM93- } \\
98-16\end{array}$ & $\begin{array}{r}\text { NM93- } \\
98-17\end{array}$ & $\begin{array}{r}\text { NM93- } \\
98-18\end{array}$ & $\begin{array}{r}\text { NM93- } \\
98-19\end{array}$ & $\begin{array}{r}\text { NM93- } \\
98-20\end{array}$ & $\begin{array}{c}\text { NM93- } \\
98-21\end{array}$ & $\begin{array}{r}\text { NM93- } \\
98-22\end{array}$ & $\begin{array}{r}\text { NM93- } \\
98-23\end{array}$ & $\begin{array}{r}\text { NM93- } \\
98-46\end{array}$ & $\begin{array}{r}\text { NM93- } \\
98-47\end{array}$ & $\begin{array}{r}\text { NM93- } \\
98-48\end{array}$ \\
\hline $\mathrm{SiO}_{2}$ & 63.61 & 63.14 & 63.65 & 64.21 & 64.27 & 63.39 & 63.09 & 63.59 & 64.04 & 64.14 & 64.31 & 64.15 \\
\hline $\mathrm{Al}_{2} \mathrm{O}_{3}$ & 18.56 & 18.49 & 19.02 & 19.06 & 18.85 & 18.98 & 18.98 & 18.46 & 18.24 & 18.76 & 18.71 & 18.56 \\
\hline $\mathrm{CaO}$ & 0.45 & 0.14 & 0.05 & 0.09 & 0.03 & 0.03 & 0.05 & 0.08 & 0.11 & 0.03 & 0.01 & 0.00 \\
\hline $\mathrm{FeO}$ & 0.05 & 0.01 & 0.11 & 0.04 & 0.00 & 0.04 & 0.01 & 0.06 & 0.07 & 0.00 & 0.05 & 0.04 \\
\hline $\mathrm{SrO}$ & 0.00 & 0.05 & 0.00 & 0.04 & 0.04 & 0.02 & 0.02 & 0.00 & 0.04 & 0.04 & 0.04 & 0.01 \\
\hline $\mathrm{BaO}$ & 0.38 & 0.31 & 0.41 & 0.24 & 0.26 & 0.56 & 1.05 & 0.25 & 0.34 & 0.46 & 0.25 & 0.25 \\
\hline $\mathrm{Na}_{2} \mathrm{O}$ & 0.92 & 0.44 & 0.33 & 0.76 & 0.49 & 0.27 & 0.32 & 0.89 & 0.30 & 0.64 & 0.78 & 0.50 \\
\hline $\mathrm{K}_{2} \mathrm{O}$ & 15.44 & 16.14 & 16.55 & 16.01 & 16.21 & 16.67 & 16.26 & 15.49 & 16.55 & 16.48 & 16.21 & 16.35 \\
\hline Total & 99.42 & 98.72 & 100.12 & 100.44 & 100.14 & 99.96 & 99.77 & 98.82 & 99.68 & 100.56 & 100.37 & 99.87 \\
\hline $\mathrm{Ab}$ & 8.1 & 3.9 & 2.9 & 6.7 & 4.3 & 2.4 & 2.9 & 8 & 2.7 & 5.6 & 6.8 & 4.5 \\
\hline An & 2.2 & 0.7 & 0.3 & 0.4 & 0.1 & 0.1 & 0.2 & 0.4 & 0.5 & 0.1 & 0 & 0 \\
\hline Or & 89.7 & 95.4 & 96.8 & 92.9 & 95.5 & 97.5 & 96.9 & 91.6 & 96.8 & 94.3 & 93.2 & 95.5 \\
\hline \multicolumn{13}{|c|}{ Redrock Granite- biotite-hornblende granite } \\
\hline & NM279 & NM279 & NM279 & NM279 & NM279 & NM279 & NM279 & NM279 & NM279 & NM279 & NM279 & NM279 \\
\hline & $-99-8$ & $-99-11$ & $-99-12$ & $-99-13$ & $-99-14$ & $-99-17$ & $-99-18$ & $-99-20$ & $-99-22$ & $-99-23$ & $-99-29$ & $-99-30$ \\
\hline $\mathrm{SiO}_{2}$ & 64.78 & 63.83 & 64.26 & 64.18 & 64.42 & 64.80 & 64.65 & 64.72 & 64.35 & 64.31 & 64.20 & 63.80 \\
\hline $\mathrm{Al}_{2} \mathrm{O}_{3}$ & 18.97 & 18.64 & 18.70 & 18.61 & 18.88 & 19.14 & 18.90 & 18.93 & 18.77 & 18.74 & 18.75 & 18.61 \\
\hline $\mathrm{CaO}$ & 0.03 & 0.04 & 0.00 & 0.02 & 0.03 & 0.11 & 0.00 & 0.03 & 0.01 & 0.00 & 0.02 & 0.08 \\
\hline $\mathrm{FeO}$ & 0.12 & 0.16 & 0.07 & 0.02 & 0.10 & 0.07 & 0.09 & 0.11 & 0.06 & 0.08 & 0.10 & 0.09 \\
\hline $\mathrm{SrO}$ & 0.02 & 0.02 & 0.02 & 0.03 & 0.05 & 0.05 & 0.00 & 0.01 & 0.00 & 0.01 & 0.01 & 0.06 \\
\hline $\mathrm{BaO}$ & 0.18 & 0.19 & 0.17 & 0.14 & 0.14 & 0.17 & 0.14 & 0.12 & 0.08 & 0.14 & 0.14 & 0.14 \\
\hline $\mathrm{Na}_{2} \mathrm{O}$ & 1.56 & 0.22 & 0.42 & 0.30 & 0.48 & 1.48 & 0.75 & 1.23 & 0.29 & 0.60 & 0.63 & 0.29 \\
\hline $\mathrm{K}_{2} \mathrm{O}$ & 15.13 & 16.58 & 16.51 & 16.60 & 16.53 & 14.98 & 16.13 & 15.46 & 16.58 & 16.29 & 16.27 & 16.51 \\
\hline Total & 100.78 & 99.68 & 100.15 & 99.90 & 100.62 & 100.79 & 100.65 & 100.61 & 100.13 & 100.16 & 100.12 & 99.58 \\
\hline $\mathrm{Ab}$ & 13.5 & 2 & 3.7 & 2.7 & 4.2 & 13 & 6.6 & 10.8 & 2.6 & 5.3 & 5.6 & 2.6 \\
\hline An & 0.1 & 0.2 & 0 & 0.1 & 0.1 & 0.5 & 0 & 0.1 & 0 & 0 & 0.1 & 0.4 \\
\hline Or & 86.4 & 97.8 & 96.2 & 97.2 & 95.6 & 86.5 & 93.4 & 89.1 & 97.3 & 94.7 & 94.3 & 97 \\
\hline
\end{tabular}


APPENDIX 2. Continued.

Redrock Granite- hornblende granite

\begin{tabular}{lrrrrrrrrrrrr}
\hline & NM19 & NM19 & NM19 & NM131 & NM131 & NM131 & NM131 & NM131 & NM131 & NM131 & NM131 & NM131 \\
& -48 & -5 & 1 & -54 & -11 & -12 & -13 & -14 & -15 & -16 & -39 & -40 \\
-41 & & & & & & & & & & & & \\
\hline $\mathrm{SiO}_{2}$ & 64.35 & 64.08 & 63.63 & 62.09 & 64.44 & 63.91 & 63.76 & 64.72 & 63.50 & 64.37 & 63.83 & 62.23 \\
$\mathrm{Al}_{2} \mathrm{O}_{3}$ & 18.44 & 18.83 & 18.67 & 18.13 & 18.81 & 18.92 & 18.70 & 19.08 & 18.81 & 18.94 & 18.75 & 18.50 \\
$\mathrm{CaO}$ & 0.02 & 0.06 & 0.12 & 0.24 & 0.00 & 0.07 & 0.07 & 0.04 & 0.02 & 0.02 & 0.04 & 0.11 \\
$\mathrm{FeO}$ & 0.20 & 0.08 & 0.07 & 0.12 & 0.04 & 0.07 & 0.03 & 0.04 & 0.06 & 0.08 & 0.09 & 0.08 \\
$\mathrm{SrO}$ & 0.03 & 0.00 & 0.00 & 0.00 & 0.00 & 0.00 & 0.02 & 0.04 & 0.01 & 0.02 & 0.01 & 0.00 \\
$\mathrm{BaO}$ & 0.27 & 0.22 & 0.18 & 0.30 & 0.16 & 0.29 & 0.26 & 0.28 & 0.32 & 0.28 & 0.26 & 0.25 \\
$\mathrm{Na}{ }_{2} \mathrm{O}$ & 0.29 & 0.34 & 0.35 & 0.47 & 1.55 & 0.72 & 0.51 & 1.30 & 0.60 & 0.47 & 0.82 & 0.61 \\
$\mathrm{~K}_{2} \mathrm{O}$ & 16.24 & 16.47 & 16.45 & 15.72 & 15.09 & 15.92 & 16.08 & 15.25 & 16.09 & 16.31 & 15.90 & 15.94 \\
$\mathrm{Total}$ & 99.84 & 100.08 & 99.46 & 97.07 & 100.09 & 99.91 & 99.44 & 100.75 & 99.40 & 100.49 & 99.69 & 97.72 \\
& & & & & & & & & & & \\
$\mathrm{Ab}$ & 2.6 & 3 & 3.1 & 4.3 & 13.5 & 6.4 & 4.6 & 11.5 & 5.4 & 4.2 & 7.3 & 5.5 \\
$\mathrm{An}$ & 0.1 & 0.3 & 0.6 & 1.2 & 0 & 0.3 & 0.3 & 0.2 & 0.1 & 0.1 & 0.2 & 0.5 \\
$\mathrm{Or}$ & 97.3 & 96.7 & 96.3 & 94.5 & 86.5 & 93.2 & 95.1 & 88.3 & 94.3 & 95.7 & 92.5 & 94
\end{tabular}

\begin{tabular}{|c|c|c|c|c|c|c|c|c|c|c|c|c|}
\hline \multicolumn{13}{|c|}{ Redrock Granite- hornblende granite } \\
\hline & NM131 & NM131 & NM131 & NM1 & NM1 & NM1 & NM1 & NM1 & NM1 & NM1 & NM1 & NM1 \\
\hline & -46 & -48 & -50 & -5 & -6 & -9 & -10 & -11 & -12 & -17 & -18 & -19 \\
\hline $\mathrm{SiO}_{2}$ & 61.93 & 62.87 & 63.57 & 64.10 & 63.28 & 65.27 & 63.99 & 63.99 & 62.45 & 63.49 & 62.91 & 62.68 \\
\hline $\mathrm{Al}_{2} \mathrm{O}_{3}$ & 18.42 & 18.31 & 18.87 & 18.84 & 18.55 & 19.10 & 19.22 & 18.81 & 18.43 & 18.76 & 18.51 & 18.62 \\
\hline $\mathrm{CaO}$ & 0.01 & 0.03 & 0.04 & 0.12 & 0.08 & 0.22 & 0.23 & 0.04 & 0.07 & 0.05 & 0.09 & 0.79 \\
\hline $\mathrm{FeO}$ & 0.02 & 0.08 & 0.38 & 0.09 & 0.98 & 0.08 & 0.15 & 0.02 & 0.15 & 0.19 & 0.76 & 0.27 \\
\hline $\mathrm{SrO}$ & 0.05 & 0.03 & 0.07 & 0.00 & 0.03 & 0.00 & 0.00 & 0.03 & 0.03 & 0.02 & 0.01 & 0.00 \\
\hline $\mathrm{BaO}$ & 0.59 & 0.51 & 0.18 & 0.27 & 0.33 & 0.26 & 0.24 & 0.29 & 0.35 & 0.44 & 0.23 & 0.28 \\
\hline $\mathrm{Na}_{2} \mathrm{O}$ & 0.40 & 0.94 & 3.97 & 1.30 & 0.32 & 3.08 & 2.62 & 0.28 & 0.30 & 0.31 & 0.96 & 0.33 \\
\hline $\mathrm{K}_{2} \mathrm{O}$ & 16.14 & 15.47 & 11.35 & 14.98 & 16.34 & 12.60 & 13.13 & 16.58 & 16.41 & 16.68 & 15.35 & 16.23 \\
\hline Total & 97.55 & 98.24 & 98.42 & 99.70 & 99.89 & 100.61 & 99.59 & 100.04 & 98.18 & 99.95 & 98.83 & 99.19 \\
\hline $\mathrm{Ab}$ & 3.6 & 8.4 & 34.6 & 11.6 & 2.9 & 26.8 & 23 & 2.5 & 2.7 & 2.7 & 8.6 & 2.9 \\
\hline An & 0 & 0.1 & 0.2 & 0.6 & 0.4 & 1.1 & 1.1 & 0.2 & 0.3 & 0.3 & 0.4 & 3.8 \\
\hline Or & 96.3 & 91.4 & 65.2 & 87.9 & 96.7 & 72.1 & 75.9 & 97.3 & 96.9 & 97 & 90.9 & 93.3 \\
\hline
\end{tabular}

\begin{tabular}{|c|c|c|c|c|c|c|}
\hline & \multicolumn{4}{|c|}{ Hornblende granite } & \multicolumn{2}{|l|}{ anorthosite } \\
\hline & NM1 & NM1 & NM1 & NM1 & NM312 & \\
\hline & -23 & -24 & -42 & -43 & -35 & \\
\hline $\mathrm{SiO}_{2}$ & 63.86 & 63.96 & 63.77 & 63.75 & 63.70 & Analytical errors, based on 12 replicate analyses of \\
\hline $\mathrm{Al}_{2} \mathrm{O}_{3}$ & 18.49 & 18.84 & 18.73 & 18.95 & 18.86 & standard reference materials MAD-10 orthoclase \\
\hline $\mathrm{CaO}$ & 0.10 & 0.05 & 0.09 & 0.03 & 0.02 & (UCB 374, used for $\mathrm{SiO}_{2}, \mathrm{Al}_{2} \mathrm{O}_{3}$, and $\mathrm{FeO}$ ), \\
\hline $\mathrm{FeO}$ & 0.08 & 0.04 & 0.12 & 0.20 & 0.06 & Cazadero albite (UCB 301, used for $\mathrm{Na}_{2} \mathrm{O}$ ) and \\
\hline $\mathrm{SrO}$ & 0.05 & 0.01 & 0.01 & 0.00 & 0.05 & Grass Valley anorthite (UCB 305, used for $\mathrm{CaO}$ ) (all \\
\hline $\mathrm{BaO}$ & 0.28 & 0.27 & 0.36 & 0.31 & 0.26 & obtained from University of California at Berkeley), \\
\hline $\mathrm{Na}_{2} \mathrm{O}$ & 0.28 & 0.31 & 0.30 & 0.32 & 0.31 & from 2 separate analytical sessions, are as follows: \\
\hline $\mathrm{K}_{2} \mathrm{O}$ & 16.77 & 16.64 & 16.56 & 16.42 & 16.64 & $\mathrm{SiO}_{2} \pm 0.4$ wt. $\%, \mathrm{Al}_{2} \mathrm{O}_{3} \pm 0.1$ wt. $\%, \mathrm{CaO} \pm 0.2$ wt. $\%$ \\
\hline Total & 99.91 & 100.12 & 99.94 & 99.99 & 99.90 & $\begin{array}{l}\mathrm{FeO} \pm 0.03 \text { wt. } \%, \mathrm{Na}_{2} \mathrm{O} \pm 0.08 \text { wt. } \% \text {, and } \mathrm{K}_{2} \mathrm{O} \pm 0.18 \\
\text { wt. } \% \text {. The levels of } \mathrm{Ba} \text { and } \mathrm{Sr} \text { in the reference }\end{array}$ \\
\hline $\mathrm{Ab}$ & 2.9 & 2.7 & 2.7 & 2.9 & 2.8 & materials are not sufficient to determine analytical \\
\hline An & 3.8 & 0.3 & 0.4 & 0.1 & 0.1 & error, but the detection limits for these two elements \\
\hline Or & 93.3 & 97 & 96.9 & 96.9 & 97.1 & are 0.07 and 0.06 wt. $\%$, respectively \\
\hline
\end{tabular}


APPENDIX 3. Plagioclase analyses of the Redrock Granite and the anorthosites.

Miarolitic biotite granite

\begin{tabular}{lrrrrrrrrrrrrrr}
\hline & $\begin{array}{r}\text { NM11 } \\
\text { NM11 }\end{array}$ & NM11 & NM11 & NM11 & NM11 & NM11 & NM11 & NM11 & NM11 & NM11 & NM11 & NM11 \\
& $-n 3$ & $-n$ & $-n 5$ & $-n 6$ & $-n 16$ & $-n 17$ & $-n 21$ & $-n 22$ & -11 & -15 & -16 & -17 & -18 \\
\hline $\mathrm{SiO}_{2}$ & 65.89 & 68.09 & 68.37 & 68.70 & 68.04 & 65.13 & 67.13 & 66.67 & 66.76 & 66.56 & 66.51 & 66.75 & 65.68 \\
$\mathrm{Al}_{2} \mathrm{O}_{3}$ & 21.74 & 20.45 & 20.38 & 20.31 & 20.52 & 22.57 & 20.19 & 21.17 & 21.09 & 21.75 & 21.20 & 21.41 & 22.04 \\
$\mathrm{CaO}$ & 2.08 & 0.45 & 0.33 & 0.14 & 0.59 & 2.93 & 0.57 & 1.61 & 1.34 & 1.81 & 1.55 & 1.04 & 2.27 \\
$\mathrm{FeO}$ & 0.04 & 0.02 & 0.04 & 0.00 & 0.05 & 0.10 & 0.00 & 0.03 & 0.00 & 0.03 & 0.01 & 0.05 & 0.06 \\
$\mathrm{SrO}$ & 0.04 & 0.03 & 0.05 & 0.03 & 0.01 & 0.00 & 0.00 & 0.00 & 0.00 & 0.02 & 0.00 & 0.05 & 0.01 \\
$\mathrm{BaO}$ & 0.00 & 0.00 & 0.00 & 0.03 & 0.01 & 0.01 & 0.04 & 0.00 & 0.01 & 0.04 & 0.01 & 0.00 & 0.01 \\
$\mathrm{Na} 2$ & 10.36 & 11.58 & 11.75 & 11.74 & 11.40 & 9.86 & 11.10 & 10.70 & 11.11 & 10.74 & 10.90 & 10.97 & 10.64 \\
$\mathrm{~K}_{2} \mathrm{O}$ & 0.11 & 0.05 & 0.02 & 0.01 & 0.06 & 0.28 & 0.05 & 0.08 & 0.13 & 0.09 & 0.08 & 0.36 & 0.14 \\
$\mathrm{Total}^{2}$ & 100.26 & 100.66 & 100.94 & 100.96 & 100.66 & 100.87 & 99.08 & 100.26 & 100.44 & 101.02 & 100.26 & 100.62 & 100.86 \\
& & & & & & & & & & & & & \\
$\mathrm{Ab}$ & 84.5 & 2.9 & 2.3 & 3 & 0.6 & 91.9 & 98.4 & 99.3 & 93.1 & 91.1 & 92.3 & 93.1 & 88.7 \\
$\mathrm{An}$ & 13.9 & 0.1 & 0 & 0 & 4.1 & 7.6 & 1.5 & 0.6 & 6.2 & 8.5 & 7.3 & 4.9 & 10.5 \\
$\mathrm{Or}$ & 1.6 & 97 & 97.7 & 97 & 95.3 & 0.5 & 0.1 & 0.1 & 0.7 & 0.5 & 0.4 & 2 & 0.8 \\
\hline
\end{tabular}

Miarolitic biotite granite

Biotite-hornblende granite

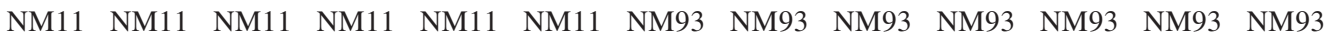
$\begin{array}{lllllllllllll}-21 & -22 & -25 & -26 & -5 & -6 & -98-2 & -98-3 & -98-4 & -98-5 & -98-6 & -98-7 & -98-8\end{array}$

$\begin{array}{llllllllllllll}\mathrm{SiO}_{2} & 64.18 & 68.76 & 66.63 & 67.23 & 66.62 & 66.37 & 62.97 & 63.13 & 64.57 & 63.27 & 63.06 & 63.51 & 62.84\end{array}$

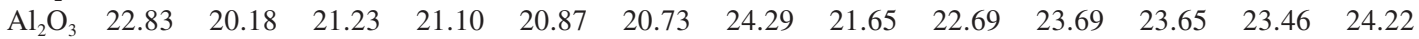

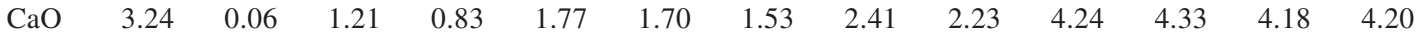

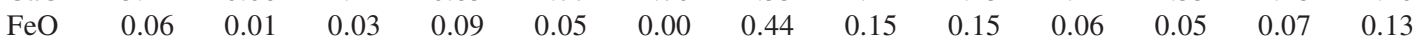

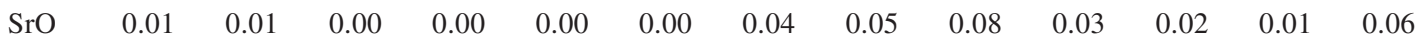

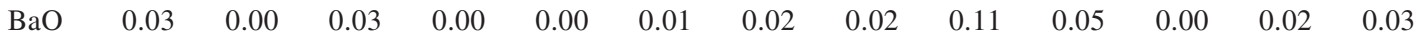

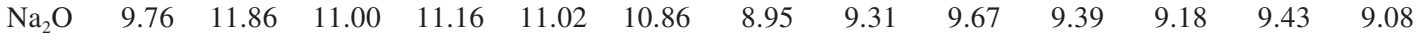

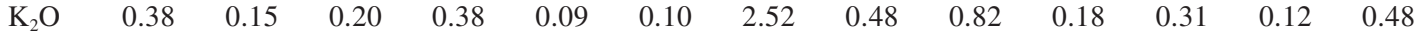

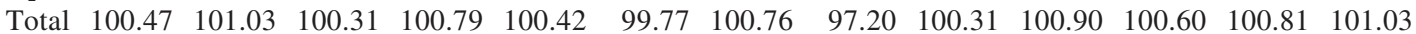

\begin{tabular}{rrrrrrrrrrrrrr}
$\mathrm{Ab}$ & 82.7 & 98.9 & 93.2 & 94 & 91.4 & 91.5 & 78.1 & 85 & 84.5 & 79.2 & 78 & 79.8 & 77.5 \\
$\mathrm{An}$ & 15.2 & 0.3 & 5.7 & 3.9 & 8.1 & 7.9 & 7.4 & 12.2 & 10.8 & 19.8 & 20.3 & 19.5 & 19.8 \\
$\mathrm{Or}$ & 2.1 & 0.8 & 1.1 & 2.1 & 0.5 & 0.5 & 14.5 & 2.9 & 4.7 & 1 & 1.7 & 0.7 & 2.7 \\
\hline
\end{tabular}

Biotite-hornblende granite

NM93 NM93 NM93 NM93 NM93 NM93 NM93 NM93 NM93 NM93 NM93 $\quad$ NM93

-98-9 -98-10 -98-11 -98-12 -98-13 -98-14 -98-38 -98-39-98-41 -98-42 -98-43-98-44 -98-45

$\begin{array}{lrrrrrrrrrrrrr}\mathrm{SiO}_{2} & 62.57 & 62.94 & 63.67 & 58.05 & 62.68 & 63.02 & 63.40 & 62.15 & 62.01 & 58.43 & 66.24 & 63.58 & 67.74 \\ \mathrm{Al}_{2} \mathrm{O}_{3} & 23.66 & 23.94 & 23.50 & 28.16 & 23.95 & 23.72 & 23.52 & 24.84 & 25.41 & 26.99 & 21.25 & 24.08 & 20.64 \\ \mathrm{CaO} & 4.64 & 4.49 & 0.90 & 0.94 & 4.68 & 4.22 & 0.70 & 0.96 & 0.93 & 0.65 & 0.96 & 1.07 & 0.45 \\ \mathrm{FeO} & 0.14 & 0.16 & 0.20 & 0.63 & 0.11 & 0.09 & 0.11 & 0.12 & 0.39 & 1.50 & 0.20 & 0.25 & 0.03 \\ \mathrm{SrO} & 0.05 & 0.05 & 0.05 & 0.05 & 0.04 & 0.07 & 0.04 & 0.04 & 0.02 & 0.05 & 0.04 & 0.04 & 0.03 \\ \mathrm{BaO} & 0.05 & 0.07 & 0.05 & 0.06 & 0.02 & 0.00 & 0.05 & 0.11 & 0.02 & 0.03 & 0.03 & 0.01 & 0.04 \\ \mathrm{Na}_{2} \mathrm{O} & 8.77 & 8.95 & 9.42 & 6.21 & 8.79 & 9.06 & 9.40 & 8.47 & 8.35 & 6.39 & 10.91 & 9.10 & 11.42 \\ \mathrm{~K}_{2} \mathrm{O} & 0.50 & 0.53 & 1.98 & 5.22 & 0.35 & 0.44 & 1.98 & 2.58 & 3.27 & 5.29 & 0.45 & 2.13 & 0.21 \\ \mathrm{Total} & 100.36 & 101.11 & 99.77 & 99.33 & 100.62 & 100.62 & 99.18 & 99.28 & 100.41 & 99.33 & 100.07 & 100.27 & 100.55 \\ & & & & & & & & & & & & & \\ \mathrm{Ab} & 75.2 & 76 & 84 & 61.1 & 75.7 & 77.6 & 23.1 & 79.1 & 75.8 & 62.4 & 92.9 & 82 & 96.7 \\ \mathrm{An} & 22 & 21.1 & 4.5 & 5.1 & 22.3 & 20 & 4.5 & 5 & 4.6 & 3.5 & 4.5 & 5.3 & 2.1 \\ \mathrm{Or} & 2.9 & 3 & 11.6 & 33.8 & 2 & 2.5 & 72.3 & 15.9 & 19.5 & 34.1 & 2.5 & 12.6 & 1.2\end{array}$


APPENDIX 3. Continued.

Biotite-hornblende granite

NM93 NM93 NM279 NM279 NM279 NM279 NM279 NM279 NM279 NM279 NM279 NM279 NM279

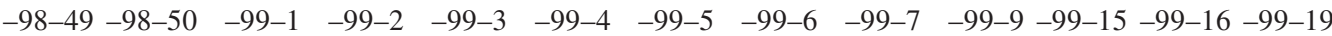

\begin{tabular}{lrrrrrrrrrrrrr}
\hline $\mathrm{SiO}_{2}$ & 67.25 & 65.50 & 67.78 & 68.64 & 67.18 & 64.42 & 63.71 & 63.99 & 64.55 & 64.26 & 66.12 & 65.72 & 66.82 \\
$\mathrm{Al}_{2} \mathrm{O}_{3}$ & 20.35 & 21.14 & 20.50 & 20.10 & 21.01 & 22.88 & 23.15 & 23.12 & 18.96 & 23.02 & 21.71 & 21.74 & 21.36 \\
$\mathrm{CaO}$ & 0.50 & 0.60 & 0.14 & 0.06 & 0.31 & 3.33 & 3.67 & 3.48 & 0.11 & 3.61 & 2.17 & 2.18 & 1.54 \\
$\mathrm{FeO}$ & 0.02 & 0.14 & 0.04 & 0.06 & 0.09 & 0.11 & 0.18 & 0.15 & 0.12 & 0.10 & 0.10 & 0.08 & 0.11 \\
$\mathrm{SrO}$ & 0.00 & 0.03 & 0.06 & 0.00 & 0.01 & 0.00 & 0.00 & 0.03 & 0.03 & 0.04 & 0.00 & 0.01 & 0.04 \\
$\mathrm{BaO}$ & 0.03 & 0.02 & 0.01 & 0.00 & 0.00 & 0.02 & 0.02 & 0.03 & 0.20 & 0.06 & 0.03 & 0.00 & 0.00 \\
$\mathrm{Na} \mathrm{O}_{2} \mathrm{O}$ & 11.20 & 10.31 & 11.61 & 11.97 & 11.05 & 9.87 & 9.50 & 9.58 & 1.69 & 9.60 & 10.37 & 10.44 & 10.90 \\
$\mathrm{~K}_{2} \mathrm{O}$ & 0.26 & 0.80 & 0.27 & 0.11 & 0.63 & 0.14 & 0.45 & 0.44 & 14.65 & 0.37 & 0.46 & 0.18 & 0.11 \\
$\mathrm{Total}$ & 99.60 & 98.54 & 100.41 & 100.95 & 100.28 & 100.78 & 100.66 & 100.82 & 100.29 & 101.06 & 100.94 & 100.34 & 100.90 \\
& & & & & & & & & & & & & \\
$\mathrm{Ab}$ & 96.2 & 92.3 & 97.8 & 100 & 95 & 83.6 & 82.2 & 81.3 & 14.8 & 81.1 & 87.4 & 88.8 & 98.6 \\
$\mathrm{An}$ & 2.4 & 3 & 0.6 & 0 & 1.5 & 15.6 & 17.5 & 16.3 & 0.5 & 16.8 & 10.1 & 10.2 & 0.8 \\
$\mathrm{Or}$ & 1.4 & 4.7 & 1.5 & 0 & 3.6 & 0.8 & 0.3 & 2.4 & 84.7 & 2 & 2.5 & 1 & 0.7 \\
\hline
\end{tabular}

Biotite-hornblende granite

Hornblende granite

NM279 NM279 NM279 NM279 NM279 NM19 NM19 NM19 NM19 NM19 NM131 NM131 NM131

-99-21 -99-24 -99-25 -99-26 -99-28 av.20pt. av.20pt. $\quad-49 \quad-52 \quad-55 \quad-2 \quad-3 \quad-4$

$\begin{array}{llllllllllllll}\mathrm{SiO}_{2} & 67.51 & 68.96 & 64.25 & 64.50 & 68.96 & 66.38 & 60.34 & 67.41 & 68.30 & 66.45 & 62.76 & 63.04 & 63.06\end{array}$

$\begin{array}{llllllllllllll}\mathrm{Al}_{2} \mathrm{O}_{3} & 20.69 & 20.05 & 23.39 & 23.01 & 20.23 & 21.17 & 25.53 & 20.93 & 20.40 & 21.10 & 23.05 & 23.21 & 23.48\end{array}$

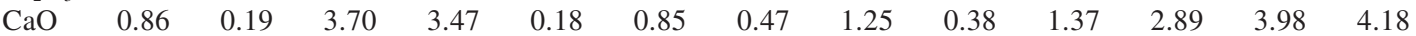

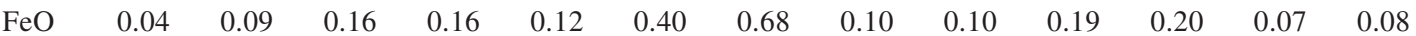

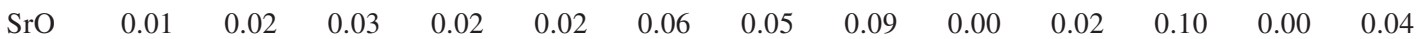

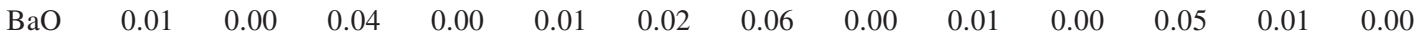

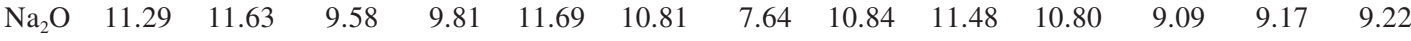

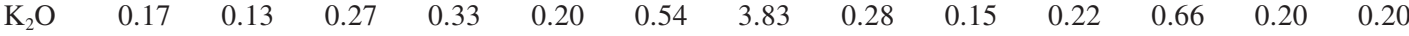

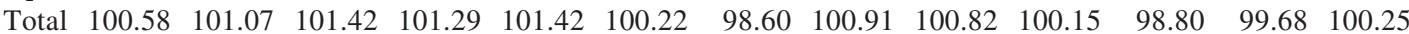

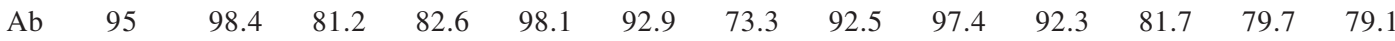

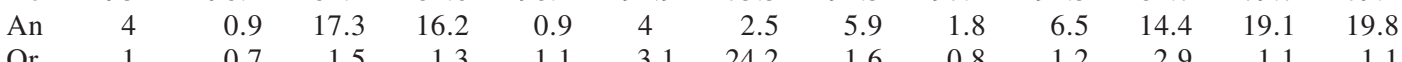

Hornblende granite

NM131 NM131 NM131 NM131 NM131 NM131 NM131 NM131 NM131 NM131 NM131 NM131 NM131

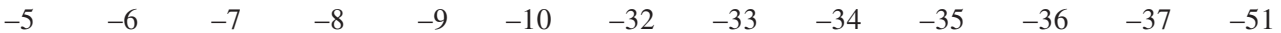

$\begin{array}{lrrrrrrrrrrrrr}\mathrm{SiO}_{2} & 63.62 & 63.37 & 63.53 & 63.83 & 63.80 & 62.56 & 59.81 & 64.64 & 61.45 & 59.77 & 63.87 & 59.59 & 67.66 \\ \mathrm{Al}_{2} \mathrm{O}_{3} & 22.92 & 22.84 & 24.59 & 22.91 & 22.50 & 22.58 & 26.62 & 22.16 & 25.50 & 24.38 & 23.81 & 24.59 & 19.69 \\ \mathrm{CaO} & 3.52 & 3.64 & 1.13 & 2.77 & 3.26 & 3.49 & 1.22 & 1.51 & 0.96 & 5.80 & 4.12 & 4.98 & 0.10 \\ \mathrm{FeO} & 0.13 & 0.21 & 0.07 & 0.13 & 0.17 & 0.09 & 0.21 & 0.10 & 0.20 & 0.12 & 0.09 & 0.14 & 0.02 \\ \mathrm{SrO} & 0.00 & 0.06 & 0.10 & 0.00 & 0.02 & 0.07 & 0.02 & 0.15 & 0.11 & 0.03 & 0.00 & 0.03 & 0.02 \\ \mathrm{BaO} & 0.02 & 0.02 & 0.16 & 0.00 & 0.06 & 0.01 & 0.08 & 0.07 & 0.06 & 0.00 & 0.00 & 0.03 & 0.04 \\ \mathrm{Na}_{2} \mathrm{O} & 9.54 & 9.52 & 9.22 & 9.56 & 9.64 & 9.37 & 7.47 & 9.93 & 7.92 & 7.99 & 9.38 & 8.03 & 11.44 \\ \mathrm{~K}_{2} \mathrm{O} & 0.24 & 0.31 & 2.18 & 0.52 & 0.25 & 0.24 & 3.40 & 0.80 & 2.69 & 0.24 & 0.30 & 0.81 & 0.33 \\ \mathrm{Total} & 100.00 & 99.98 & 100.96 & 99.72 & 99.69 & 98.41 & 98.82 & 99.36 & 98.88 & 98.33 & 101.58 & 98.20 & 99.29 \\ & & & & & & & & & & & & & \\ \mathrm{Ab} & 81.9 & 81.1 & 81.7 & 83.6 & 83.1 & 81.8 & 72 & 87.9 & 77.5 & 70.4 & 79.1 & 71 & 97.7 \\ \mathrm{An} & 16.7 & 17.1 & 5.5 & 13.4 & 15.5 & 16.8 & 6.5 & 7.4 & 5.2 & 28.2 & 19.2 & 24.3 & 0.5 \\ \mathrm{Or} & 1.4 & 1.7 & 12.7 & 3 & 1.4 & 1.4 & 21.5 & 4.7 & 17.3 & 1.4 & 1.7 & 4.7 & 1.8\end{array}$


APPENDIX 3. Continued.

Hornblende granite

\begin{tabular}{|c|c|c|c|c|c|c|c|c|c|c|c|c|c|}
\hline & $\begin{array}{r}\text { NM1 } \\
-1\end{array}$ & $\begin{array}{r}\text { NM1 } \\
-2\end{array}$ & $\begin{array}{r}\text { NM1 } \\
-3\end{array}$ & $\begin{array}{r}\text { NM1 } \\
-4\end{array}$ & $\begin{array}{r}\text { NM1 } \\
-7\end{array}$ & $\begin{array}{r}\text { NM1 } \\
-8\end{array}$ & $\begin{array}{r}\text { NM1 } \\
-13\end{array}$ & $\begin{array}{r}\text { NM1 } \\
-14\end{array}$ & $\begin{array}{r}\text { NM1 } \\
-20\end{array}$ & $\begin{array}{r}\text { NM1 } \\
-21\end{array}$ & $\begin{array}{r}\text { NM1 } \\
-22\end{array}$ & $\begin{array}{r}\text { NM1 } \\
-25\end{array}$ & $\begin{array}{r}\text { NM1 } \\
-26\end{array}$ \\
\hline $\mathrm{SiO}_{2}$ & 66.52 & 66.05 & 65.14 & 67.47 & 66.93 & 68.43 & 68.37 & 68.48 & 66.37 & 64.71 & 66.89 & 67.35 & 67.51 \\
\hline $\mathrm{Al}_{2} \mathrm{O}_{3}$ & 20.44 & 20.10 & 21.29 & 21.03 & 20.49 & 19.77 & 20.38 & 20.12 & 20.86 & 21.65 & 20.94 & 20.61 & 20.74 \\
\hline $\mathrm{CaO}$ & 0.49 & 0.62 & 0.95 & 0.32 & 0.70 & 0.13 & 0.37 & 1.04 & 0.47 & 0.67 & 0.46 & 0.85 & 0.68 \\
\hline $\mathrm{FeO}$ & 0.16 & 0.03 & 0.63 & 0.10 & 0.11 & 0.11 & 0.02 & 0.06 & 0.24 & 0.49 & 0.15 & 0.15 & 0.16 \\
\hline $\mathrm{SrO}$ & 0.01 & 0.01 & 0.01 & 0.01 & 0.02 & 0.03 & 0.04 & 0.02 & 0.05 & 0.03 & 0.04 & 0.03 & 0.04 \\
\hline $\mathrm{BaO}$ & 0.04 & 0.01 & 0.09 & 0.07 & 0.02 & 0.00 & 0.05 & 0.02 & 0.00 & 0.06 & 0.01 & 0.02 & 0.04 \\
\hline $\mathrm{Na}_{2} \mathrm{O}$ & 10.89 & 11.09 & 10.04 & 11.06 & 11.05 & 11.58 & 11.60 & 10.64 & 10.83 & 10.01 & 10.93 & 11.10 & 11.29 \\
\hline $\mathrm{K}_{2} \mathrm{O}$ & 0.27 & 0.16 & 0.83 & 0.49 & 0.12 & 0.13 & 0.12 & 0.10 & 0.52 & 1.13 & 0.51 & 0.18 & 0.20 \\
\hline Total & 98.81 & 98.06 & 98.98 & 100.54 & 99.44 & 100.19 & 100.96 & 100.47 & 99.33 & 98.77 & 99.93 & 100.28 & 100.66 \\
\hline $\mathrm{Ab}$ & 96.1 & 96.1 & 90.4 & 95.7 & 96 & 98.7 & 97.6 & 94.3 & 94.8 & 90 & 94.9 & 95 & 95.7 \\
\hline An & 2.4 & 3 & 4.7 & 1.5 & 3.4 & 0.6 & 1.7 & 5.1 & 2.3 & 3.3 & 2.2 & 4 & 3.2 \\
\hline Or & 1.5 & 0.9 & 4.9 & 2.8 & 0.7 & 0.7 & 0.7 & 0.6 & 3 & 6.7 & 2.9 & 1 & 1.1 \\
\hline
\end{tabular}

\begin{tabular}{lrrrrrrrrrrrrrr}
\hline \multicolumn{1}{c}{ Hornblende granite } & \multicolumn{1}{c}{ Anorthosites } & & & & \\
\hline & NM1 & NM1 & NM1 & NM1 & Red7 & Red7 & Red7 & Red7 & Red7 & Red7 & Red7 NM312 NM312 \\
& -40 & -41 & -44 & -45 & -1 & -2 & -3 & -4 & -6 & -8 & -10 & -3 & -4 \\
\hline $\mathrm{SiO}_{2}$ & 65.24 & 65.16 & 68.18 & 68.17 & 53.04 & 55.50 & 53.71 & 54.29 & 52.74 & 62.34 & 53.06 & 67.49 & 68.60 \\
$\mathrm{Al}_{2} \mathrm{O}_{3}$ & 21.41 & 20.54 & 20.24 & 20.40 & 29.83 & 29.42 & 29.36 & 30.09 & 29.99 & 23.75 & 29.82 & 20.04 & 20.02 \\
$\mathrm{CaO}$ & 1.81 & 1.75 & 0.27 & 0.65 & 11.87 & 1.33 & 10.49 & 2.11 & 12.00 & 3.97 & 11.22 & 0.05 & 0.02 \\
$\mathrm{FeO}$ & 0.12 & 0.14 & 0.28 & 0.10 & 0.31 & 0.80 & 0.23 & 0.38 & 0.23 & 0.07 & 0.29 & 0.13 & 0.05 \\
$\mathrm{SrO}$ & 0.07 & 0.02 & 0.00 & 0.00 & 0.03 & 0.08 & 0.02 & 0.11 & 0.02 & 0.05 & 0.10 & 0.00 & 0.05 \\
$\mathrm{BaO}$ & 0.05 & 0.06 & 0.01 & 0.04 & 0.01 & 0.11 & 0.00 & 0.14 & 0.01 & 0.00 & 0.00 & 0.00 & 0.00 \\
$\mathrm{Na} \mathrm{O}_{2}$ & 10.57 & 10.30 & 11.39 & 11.35 & 4.61 & 3.98 & 4.57 & 3.72 & 4.45 & 8.96 & 4.42 & 11.98 & 11.87 \\
$\mathrm{~K}_{2} \mathrm{O}$ & 0.16 & 0.21 & 0.35 & 0.09 & 0.30 & 5.84 & 0.73 & 5.53 & 0.32 & 0.39 & 0.64 & 0.05 & 0.04 \\
$\mathrm{Total}$ & 99.44 & 98.17 & 100.72 & 100.79 & 100.01 & 97.06 & 99.10 & 96.36 & 99.76 & 99.54 & 99.56 & 99.75 & 100.65 \\
& & & & & & & & & & & & \\
$\mathrm{Ab}$ & 90.5 & 90.3 & 96.8 & 96.5 & 40.6 & 46.5 & 42.1 & 43.6 & 39.4 & 78.5 & 40 & 99.5 & 99.7 \\
$\mathrm{An}$ & 8.6 & 8.5 & 1.2 & 3 & 57.7 & 8.6 & 53.4 & 13.7 & 58.7 & 19.2 & 56.1 & 0.2 & 0.1 \\
$\mathrm{Or}$ & 0.9 & 1.2 & 2 & 0.5 & 1.7 & 44.9 & 4.4 & 42.7 & 1.9 & 2.2 & 3.8 & 0.3 & 0.2 \\
\hline
\end{tabular}

Anorthosites

\begin{tabular}{|c|c|c|c|c|c|c|c|c|c|c|c|c|c|}
\hline $\mathrm{I}$ & $\begin{array}{r}\text { NM312 } \\
-9\end{array}$ & $\begin{array}{r}\mathrm{NM} 312 \\
-10\end{array}$ & $\begin{array}{r}\text { NM312 } \\
-11\end{array}$ & $\begin{array}{r}\mathrm{JM} 312 \\
-18\end{array}$ & $\begin{array}{r}\text { NM312 } \\
-19\end{array}$ & $\begin{array}{r}\text { NM312 } \\
-32\end{array}$ & $\begin{array}{r}\mathrm{VM} 312 \\
-33\end{array}$ & $\begin{array}{r}\mathrm{VM} 312 \\
-34\end{array}$ & $\begin{array}{r}\text { Red4 } \\
-1\end{array}$ & $\begin{array}{r}\text { Red4 } \\
-2\end{array}$ & $\begin{array}{r}\text { Red4 } \\
-3\end{array}$ & $\begin{array}{r}\text { Red4 } \\
-4\end{array}$ & $\begin{array}{r}\operatorname{Red} 4 \\
-5\end{array}$ \\
\hline $\mathrm{SiO}_{2}$ & 67.63 & 65.08 & 67.31 & 64.02 & 53.08 & 67.81 & 61.53 & 61.52 & 55.68 & 56.39 & 68.56 & 68.56 & 59.14 \\
\hline $\mathrm{Al}_{2} \mathrm{O}_{3}$ & 19.98 & 20.34 & 20.34 & 21.96 & 29.44 & 20.91 & 23.83 & 23.63 & 28.79 & 28.30 & 20.26 & 20.26 & 28.32 \\
\hline $\mathrm{CaO}$ & 0.09 & 1.97 & 1.25 & 1.75 & 0.48 & 0.65 & 0.77 & 1.40 & 10.36 & 9.73 & 0.27 & 0.27 & 3.21 \\
\hline $\mathrm{FeO}$ & 0.09 & 0.57 & 0.24 & 0.11 & 0.89 & 0.15 & 0.52 & 0.67 & 0.19 & 0.19 & 0.15 & 0.15 & 0.08 \\
\hline $\mathrm{SrO}$ & 0.00 & 0.00 & 0.06 & 0.14 & 0.08 & 0.03 & 0.04 & 0.11 & 0.09 & 0.08 & 0.02 & 0.02 & 0.15 \\
\hline $\mathrm{BaO}$ & 0.00 & 0.02 & 0.06 & 0.00 & 0.27 & 0.02 & 0.05 & 0.00 & 0.04 & 0.02 & 0.00 & 0.00 & 0.04 \\
\hline $\mathrm{Na}_{2} \mathrm{O}$ & 11.66 & 10.97 & 11.22 & 10.21 & 4.20 & 11.58 & 9.18 & 8.72 & 5.64 & 6.08 & 11.67 & 11.67 & 8.32 \\
\hline $\mathrm{K}_{2} \mathrm{O}$ & 0.02 & 0.04 & 0.04 & 0.38 & 6.54 & 0.11 & 2.22 & 2.06 & 0.22 & 0.18 & 0.04 & 0.04 & 1.03 \\
\hline Total & 99.45 & 98.99 & 100.51 & 98.57 & 94.99 & 101.26 & 98.14 & 98.10 & 101.01 & 100.97 & 100.96 & 100.96 & 100.29 \\
\hline $\mathrm{Ab}$ & 99.5 & 90.8 & 94 & 89.3 & 47.9 & 96.4 & 83 & 80.4 & 49 & 52.5 & 98.5 & 98.5 & 77.2 \\
\hline An & 0.4 & 9 & 5.8 & 8.5 & 3 & 3 & 3.8 & 7.1 & 49.7 & 46.4 & 1.2 & 1.2 & 16.5 \\
\hline Or & 0.1 & 0.2 & 0.2 & 2.2 & 49.1 & 0.6 & 13.2 & 12.5 & 1.3 & 1 & 0.3 & 0.3 & 6.3 \\
\hline
\end{tabular}


APPENDIX 3. Continued.

\begin{tabular}{lrrrrrrrrrrrrrr}
\hline \multicolumn{1}{c}{ Anorthosites } & \multicolumn{10}{c}{10} \\
\hline & Red4 & Red4 & Red4 & Red4 & Red4 & Red4 & Red4 & Red4 & Red4 & Red4 & Red4 & Red4 & Red4 \\
& -6 & -19 & -20 & -23 & -24 & -27 & -28 & -31 & -32 & -35 & -36 & -39 & -40 \\
\hline $\mathrm{SiO}_{2}$ & 55.74 & 53.06 & 55.04 & 62.85 & 65.13 & 55.29 & 54.20 & 68.36 & 67.79 & 53.14 & 52.43 & 67.71 & 67.98 \\
$\mathrm{Al}_{2} \mathrm{O}_{3}$ & 31.61 & 30.03 & 29.22 & 25.12 & 22.57 & 28.94 & 29.72 & 20.31 & 20.75 & 30.09 & 30.26 & 20.22 & 20.27 \\
$\mathrm{CaO}$ & 2.37 & 11.79 & 10.87 & 2.21 & 2.50 & 10.88 & 11.48 & 0.49 & 0.66 & 11.95 & 12.31 & 0.39 & 0.31 \\
$\mathrm{FeO}$ & 0.15 & 0.66 & 0.26 & 0.06 & 0.06 & 0.28 & 0.26 & 0.01 & 0.13 & 0.37 & 0.28 & 0.00 & 0.04 \\
$\mathrm{SrO}$ & 0.20 & 0.08 & 0.08 & 0.11 & 0.11 & 0.07 & 0.13 & 0.03 & 0.04 & 0.11 & 0.07 & 0.02 & 0.06 \\
$\mathrm{BaO}$ & 0.05 & 0.01 & 0.01 & 0.00 & 0.01 & 0.00 & 0.01 & 0.04 & 0.02 & 0.00 & 0.01 & 0.04 & 0.00 \\
$\mathrm{Na} \mathrm{O}_{2}$ & 7.82 & 4.57 & 5.48 & 9.37 & 10.36 & 5.34 & 5.05 & 11.57 & 11.54 & 4.68 & 4.55 & 11.50 & 11.67 \\
$\mathrm{~K}_{2} \mathrm{O}$ & 1.06 & 0.39 & 0.30 & 0.83 & 0.05 & 0.30 & 0.23 & 0.05 & 0.05 & 0.23 & 0.32 & 0.04 & 0.07 \\
$\mathrm{Total}$ & 99.00 & 100.60 & 101.26 & 100.54 & 100.79 & 101.09 & 101.08 & 100.87 & 100.97 & 100.57 & 100.24 & 99.91 & 100.40 \\
$\mathrm{Ab}$ & 79.6 & 40.3 & 46.9 & 84.1 & 87.9 & 46.2 & 43.8 & 97.4 & 96.7 & 40.9 & 39.4 & 98 & 98.2 \\
$\mathrm{An}$ & 13.3 & 57.5 & 51.4 & 10.9 & 11.8 & 52.1 & 54.9 & 2.3 & 3.1 & 57.7 & 58.8 & 1.8 & 1.4 \\
$\mathrm{Or}$ & 7.1 & 2.3 & 1.7 & 4.9 & 0.3 & 1.7 & 1.3 & 0.3 & 0.3 & 1.3 & 1.8 & 0.2 & 0.4 \\
\hline
\end{tabular}

Analytical error, based on 12 replicate analyses of standard reference materials MAD-10 orthoclase (UCB 374 used for $\mathrm{SiO}_{2}, \mathrm{Al}_{2} \mathrm{O}_{3}$, and $\mathrm{FeO}$ ), Cazadero albite (UCB 301, used for $\mathrm{Na}_{2} \mathrm{O}$ ) and Grass Valley anorthite (UCB 305, used for CaO) (all obtained from University of California at Berkeley), from 2 separate analytical sessions, are as follows: $\mathrm{SiO}_{2} \pm 0.4$ wt. $\%, \mathrm{Al}_{2} \mathrm{O}_{3} \pm 0.1$ wt. $\%, \mathrm{CaO} \pm 0.2$ wt. $\%, \mathrm{FeO} \pm 0.03$ wt. $\%, \mathrm{Na}_{2} \mathrm{O} \pm 0.08$ wt. $\%$, and $\mathrm{K}_{2} \mathrm{O} \pm 0.18$ wt. $\%$. The levels of $\mathrm{Ba}$ and $\mathrm{Sr}$ in the reference materials are not sufficient to determine analytical error, but the detection limits for these two elements are 0.07 and $0.06 \mathrm{wt} . \%$, respectively. 
APPENDIX 4. Amphibole analyses of the Redrock Granite.

\begin{tabular}{|c|c|c|c|c|c|c|c|c|c|c|c|c|}
\hline & \multicolumn{12}{|c|}{ Biotite-hornblende granite } \\
\hline & $\begin{array}{r}\text { NM93 } \\
-98-25\end{array}$ & $\begin{array}{r}\text { NM93 } \\
-98-30\end{array}$ & $\begin{array}{r}\text { NM93 } \\
-98-31\end{array}$ & $\begin{array}{r}\text { NM93 } \\
-98-32\end{array}$ & $\begin{array}{r}\text { NM93 } \\
-98-33\end{array}$ & $\begin{array}{r}\text { NM93 } \\
-98-35\end{array}$ & $\begin{array}{r}\text { NM93 } \\
-98-53\end{array}$ & $\begin{array}{r}\text { NM93 } \\
-98-54\end{array}$ & $\begin{array}{l}\text { NM279 } \\
-99-37\end{array}$ & $\begin{array}{l}\text { NM279 } \\
-99-38\end{array}$ & $\begin{array}{l}\text { NM279 } \\
-99-39\end{array}$ & $\begin{array}{l}\text { NM279 } \\
-99-40\end{array}$ \\
\hline $\mathrm{SiO}_{2}$ & 42.62 & 39.93 & 40.23 & 40.37 & 41.13 & 40.61 & 39.10 & 38.41 & 39.33 & 39.11 & 39.31 & 38.91 \\
\hline $\mathrm{TiO}_{2}$ & 1.64 & 1.25 & 1.28 & 1.56 & 1.61 & 1.32 & 1.62 & 1.63 & 1.59 & 1.39 & 1.70 & 1.90 \\
\hline $\mathrm{Al}_{2} \mathrm{O}_{3}$ & 9.28 & 8.65 & 9.06 & 8.49 & 8.79 & 8.27 & 8.12 & 8.52 & 7.94 & 7.59 & 7.33 & 7.58 \\
\hline $\mathrm{MgO}$ & 3.65 & 2.94 & 2.90 & 3.27 & 3.15 & 3.02 & 2.59 & 2.53 & 2.26 & 2.30 & 2.23 & 2.24 \\
\hline $\mathrm{CaO}$ & 10.08 & 10.08 & 10.22 & 9.79 & 9.98 & 10.09 & 10.13 & 10.27 & 9.67 & 9.64 & 9.58 & 9.61 \\
\hline $\mathrm{MnO}$ & 0.74 & 0.81 & 0.81 & 0.80 & 0.82 & 0.81 & 0.86 & 0.90 & 0.57 & 0.64 & 0.59 & 0.51 \\
\hline $\mathrm{FeO}$ & 28.53 & 30.07 & 29.82 & 29.72 & 29.52 & 30.13 & 30.31 & 30.10 & 31.50 & 31.81 & 31.68 & 31.57 \\
\hline $\mathrm{Na}_{2} \mathrm{O}$ & 2.16 & 1.74 & 1.88 & 1.89 & 1.98 & 1.77 & 1.66 & 1.71 & 1.99 & 2.05 & 1.97 & 1.96 \\
\hline $\mathrm{K}_{2} \mathrm{O}$ & 1.29 & 1.27 & 1.33 & 1.29 & 1.29 & 1.21 & 1.28 & 1.27 & 1.35 & 1.32 & 1.38 & 1.36 \\
\hline $\mathrm{H}_{2} \mathrm{O}$ & 1.70 & 1.74 & 1.85 & 1.85 & 1.57 & 1.63 & 1.60 & 1.63 & 1.55 & 1.68 & 1.39 & 1.79 \\
\hline $\mathrm{F}$ & 0.48 & 0.21 & 0.00 & 0.00 & 0.64 & 0.45 & 0.43 & 0.34 & 0.54 & 0.23 & 0.86 & 0.00 \\
\hline Total & 102.16 & 98.67 & 99.37 & 99.04 & 100.48 & 99.30 & 97.70 & 97.31 & 98.27 & 97.75 & 98.00 & 97.42 \\
\hline $\mathrm{Fe}$ & 22.12 & 23.31 & 23.11 & 23.04 & 22.89 & 23.36 & 23.50 & 23.34 & 24.42 & 24.66 & 24.56 & 24.47 \\
\hline $\mathrm{Mg}$ & 2.20 & 1.77 & 1.75 & 1.98 & 1.90 & 1.82 & 1.56 & 1.52 & 1.36 & 1.39 & 1.35 & 1.35 \\
\hline $\mathrm{Fe} /(\mathrm{Fe}+\mathrm{Mg})$ & 0.91 & 0.93 & 0.93 & 0.92 & 0.92 & 0.93 & 0.94 & 0.94 & 0.95 & 0.95 & 0.95 & 0.95 \\
\hline
\end{tabular}

\begin{tabular}{lrrrrrrrrrrrr}
\hline \multicolumn{1}{c}{ Hornblende granite } & & & & & & & & & \\
\hline & $N M 1$ & NM1 & NM1 & NM1 & NM1 & NM1 & NM1 & NM1 & NM1 & NM1 & NM1 & NM1 \\
& -15 & -27 & -28 & -30 & -31 & -32 & -33 & -34 & -35 & -36 & -37 & -38 \\
\hline $\mathrm{SiO}_{2}$ & 46.35 & 41.70 & 41.56 & 39.12 & 39.93 & 46.28 & 37.31 & 38.83 & 38.83 & 38.31 & 39.00 & 39.01 \\
$\mathrm{TiO}_{2}$ & 0.28 & 0.14 & 0.08 & 1.95 & 1.91 & 0.05 & 0.00 & 1.91 & 1.89 & 1.93 & 1.93 & 1.88 \\
$\mathrm{Al}_{2} \mathrm{O}_{3}$ & 3.83 & 6.96 & 7.20 & 7.20 & 7.30 & 3.73 & 10.51 & 7.97 & 7.92 & 8.00 & 7.98 & 7.87 \\
$\mathrm{MgO}$ & 2.83 & 0.78 & 0.87 & 0.63 & 0.70 & 0.54 & 0.14 & 0.87 & 0.83 & 0.84 & 0.85 & 0.82 \\
$\mathrm{CaO}$ & 10.59 & 11.00 & 11.33 & 10.05 & 10.17 & 10.60 & 10.95 & 10.38 & 10.23 & 10.40 & 10.26 & 10.24 \\
$\mathrm{MnO}$ & 0.49 & 0.43 & 0.37 & 0.61 & 0.62 & 0.47 & 0.35 & 0.57 & 0.58 & 0.54 & 0.59 & 0.56 \\
$\mathrm{FeO}$ & 34.41 & 34.33 & 33.52 & 33.15 & 33.55 & 35.80 & 34.47 & 32.97 & 33.13 & 33.23 & 33.19 & 33.37 \\
$\mathrm{Na} 2 \mathrm{O}$ & 0.50 & 1.03 & 0.80 & 1.97 & 1.90 & 0.66 & 1.30 & 2.01 & 3.86 & 1.25 & 1.96 & 2.00 \\
$\mathrm{~K}_{2} \mathrm{O}$ & 0.46 & 1.32 & 1.59 & 1.29 & 1.23 & 0.78 & 2.05 & 1.44 & 1.45 & 1.48 & 1.46 & 1.50 \\
$\mathrm{H}_{2} \mathrm{O}$ & 1.87 & 1.77 & 1.82 & 1.69 & 1.61 & 1.81 & 1.69 & 1.53 & 1.56 & 1.58 & 1.56 & 1.59 \\
$\mathrm{~F}$ & 0.05 & 0.11 & 0.00 & 0.19 & 0.42 & 0.11 & 0.19 & 0.56 & 0.54 & 0.43 & 0.52 & 0.45 \\
$\mathrm{Total}$ & 101.66 & 99.57 & 99.12 & 97.83 & 99.32 & 100.83 & 98.95 & 99.03 & 100.81 & 97.99 & 99.29 & 99.29 \\
& & & & & & & & & & & & \\
$\mathrm{Fe}$ & 26.67 & 26.61 & 25.98 & 25.70 & 26.01 & 27.75 & 26.72 & 25.56 & 25.68 & 25.76 & 25.73 & 25.86 \\
$\mathrm{Mg}$ & 1.70 & 0.47 & 0.53 & 0.38 & 0.42 & 0.33 & 0.08 & 0.52 & 0.50 & 0.51 & 0.51 & 0.49 \\
$\mathrm{Fe} /(\mathrm{Fe}+\mathrm{Mg})$ & 0.94 & 0.98 & 0.98 & 0.99 & 0.98 & 0.99 & 1.00 & 0.98 & 0.98 & 0.98 & 0.98 & 0.98 \\
\hline
\end{tabular}


APPENDIX 4. Continued.

\begin{tabular}{|c|c|c|c|c|c|c|c|c|c|c|c|c|}
\hline \multicolumn{13}{|c|}{ Hornblende granite } \\
\hline & NM1 & NM1 & NM1 & NM1 & NM1 & NM1 & NM1 & NM1 & NM1 & NM1 & NM1 & NM1 \\
\hline & -46 & -47 & -48 & -49 & -50 & -51 & -60 & -61 & -62 & -63 & -64 & -66 \\
\hline $\mathrm{SiO}_{2}$ & 41.03 & 39.51 & 39.15 & 40.03 & 39.86 & 40.43 & 41.88 & 47.36 & 47.70 & 45.76 & 40.00 & 49.32 \\
\hline $\mathrm{TiO}_{2}$ & 1.71 & 1.91 & 1.79 & 1.59 & 1.55 & 1.62 & 0.20 & 0.54 & 0.77 & 0.21 & 0.15 & 0.69 \\
\hline $\mathrm{Al}_{2} \mathrm{O}_{3}$ & 6.91 & 7.64 & 8.69 & 6.88 & 6.92 & 6.94 & 8.40 & 3.79 & 3.92 & 3.39 & 10.87 & 3.27 \\
\hline $\mathrm{MgO}$ & 0.78 & 0.73 & 0.72 & 0.73 & 0.75 & 0.72 & 2.39 & 7.53 & 8.99 & 4.56 & 2.79 & 10.21 \\
\hline $\mathrm{CaO}$ & 10.34 & 10.31 & 10.15 & 10.16 & 10.27 & 10.10 & 11.21 & 10.69 & 10.86 & 11.07 & 11.38 & 11.17 \\
\hline $\mathrm{MnO}$ & 0.62 & 0.62 & 0.72 & 0.72 & 0.67 & 0.71 & 0.23 & 0.45 & 0.42 & 0.67 & 0.23 & 0.42 \\
\hline $\mathrm{FeO}$ & 33.56 & 33.25 & 33.42 & 33.22 & 33.64 & 33.83 & 30.83 & 25.12 & 23.01 & 29.22 & 28.73 & 21.14 \\
\hline $\mathrm{Na}_{2} \mathrm{O}$ & 1.95 & 2.08 & 1.99 & 2.02 & 1.95 & 2.03 & 1.10 & 0.94 & 1.23 & 0.65 & 1.01 & 1.30 \\
\hline $\mathrm{K}_{2} \mathrm{O}$ & 1.24 & 1.28 & 1.24 & 1.12 & 1.20 & 1.17 & 1.10 & 0.61 & 0.55 & 0.34 & 1.36 & 0.44 \\
\hline $\mathrm{H}_{2} \mathrm{O}$ & 1.75 & 1.56 & 1.67 & 1.46 & 1.54 & 1.55 & 1.62 & 1.31 & 1.95 & 1.80 & 1.85 & 1.67 \\
\hline $\mathrm{F}$ & 0.18 & 0.53 & 0.33 & 0.71 & 0.54 & 0.55 & 0.48 & 1.30 & 0.00 & 0.13 & 0.00 & 0.66 \\
\hline Total & 100.05 & 99.42 & 99.86 & 98.63 & 98.89 & 99.63 & 99.44 & 99.65 & 99.40 & 97.79 & 98.37 & 100.29 \\
\hline $\mathrm{Fe}$ & 26.01 & 25.77 & 25.91 & 25.76 & 26.08 & 26.22 & 23.90 & 19.47 & 17.84 & 22.65 & 22.27 & 16.39 \\
\hline $\mathrm{Mg}$ & 0.47 & 0.44 & 0.44 & 0.44 & 0.45 & 0.44 & 1.44 & 4.54 & 5.42 & 2.75 & 1.68 & 6.16 \\
\hline $\mathrm{Fe} /(\mathrm{Fe}+\mathrm{Mg})$ & 0.98 & 0.98 & 0.98 & 0.98 & 0.98 & 0.98 & 0.94 & 0.81 & 0.77 & 0.89 & 0.93 & 0.73 \\
\hline \multicolumn{13}{|c|}{ Hornblende granite } \\
\hline & NM19 & NM19 & NM19 & NM19 & NM19 & NM131 & NM131 & NM131 & NM131 & NM131 & NM131 & NM131 \\
\hline & -67 & -68 & -69 & -70 & -71 & -22 & -23 & -24 & -25 & -26 & -27 & -42 \\
\hline $\mathrm{SiO}_{2}$ & 48.63 & 49.13 & 48.20 & 48.45 & 49.23 & 39.12 & 38.05 & 38.73 & 39.04 & 39.24 & 38.24 & 38.78 \\
\hline $\mathrm{TiO}_{2}$ & 0.47 & 0.75 & 0.16 & 0.69 & 0.19 & 1.41 & 1.39 & 1.50 & 1.46 & 1.66 & 1.47 & 1.43 \\
\hline $\mathrm{Al}_{2} \mathrm{O}_{3}$ & 2.70 & 3.40 & 3.35 & 3.46 & 2.16 & 8.21 & 8.32 & 8.27 & 8.01 & 8.32 & 8.41 & 8.44 \\
\hline $\mathrm{MgO}$ & 6.75 & 10.51 & 6.00 & 8.68 & 5.70 & 2.23 & 2.09 & 2.02 & 2.14 & 2.05 & 2.10 & 2.24 \\
\hline $\mathrm{CaO}$ & 11.12 & 11.08 & 11.61 & 10.93 & 11.32 & 9.67 & 9.54 & 9.72 & 9.87 & 9.70 & 9.88 & 9.18 \\
\hline $\mathrm{MnO}$ & 0.56 & 0.34 & 0.31 & 0.41 & 0.61 & 1.22 & 1.05 & 1.16 & 1.07 & 1.17 & 1.17 & 1.07 \\
\hline $\mathrm{FeO}$ & 26.80 & 21.10 & 27.45 & 23.65 & 28.26 & 30.74 & 31.58 & 31.09 & 31.07 & 30.63 & 30.92 & 30.86 \\
\hline $\mathrm{Na}_{2} \mathrm{O}$ & 0.60 & 1.18 & 0.51 & 1.13 & 0.41 & 1.94 & 1.57 & 1.89 & 1.73 & 1.88 & 1.76 & 1.85 \\
\hline $\mathrm{K}_{2} \mathrm{O}$ & 0.34 & 0.66 & 0.49 & 0.45 & 0.26 & 1.29 & 1.30 & 1.29 & 1.22 & 1.26 & 1.31 & 1.33 \\
\hline $\mathrm{H}_{2} \mathrm{O}$ & 0.00 & 1.72 & 1.93 & 1.67 & 1.93 & 1.47 & 0.03 & 1.43 & 1.50 & 1.53 & 1.06 & 1.47 \\
\hline $\mathrm{F}$ & 0.00 & 0.56 & 0.00 & 0.62 & 0.00 & 0.70 & 3.67 & 0.77 & 0.62 & 0.57 & 1.52 & 0.67 \\
\hline Total & 97.97 & 100.45 & 100.01 & 100.13 & 100.07 & 97.99 & 98.59 & 97.85 & 97.73 & 98.00 & 97.83 & 97.31 \\
\hline $\mathrm{Fe}$ & 20.78 & 16.36 & 21.28 & 18.33 & 21.91 & 23.83 & 24.48 & 24.10 & 24.08 & 23.74 & 23.97 & 23.93 \\
\hline $\mathrm{Mg}$ & 4.07 & 6.34 & 3.62 & 5.24 & 3.44 & 1.35 & 1.26 & 1.22 & 1.29 & 1.24 & 1.27 & 1.35 \\
\hline $\mathrm{Fe} /(\mathrm{Fe}+\mathrm{Mg})$ & 0.84 & 0.72 & 0.86 & 0.78 & 0.86 & 0.95 & 0.95 & 0.95 & 0.95 & 0.95 & 0.95 & 0.95 \\
\hline
\end{tabular}


APPENDIX 4. Continued.

\begin{tabular}{|c|c|c|c|c|c|c|}
\hline \multicolumn{7}{|c|}{ Hornblende granite } \\
\hline & NM312 & NM312 & NM312 & NM312 & NM312 & \\
\hline & -22 & -26 & -38 & -39 & -41 & \\
\hline $\mathrm{SiO}_{2}$ & 43.85 & 50.39 & 45.91 & 39.60 & 46.22 & Analytical error, based on 12 replicate analyses of \\
\hline $\mathrm{TiO}_{2}$ & 1.26 & 0.14 & 1.16 & 0.24 & 1.12 & standard reference material Kakanui hornblende \\
\hline $\mathrm{Al}_{2} \mathrm{O}_{3}$ & 6.07 & 1.37 & 6.56 & 12.17 & 6.48 & (obtained from the Smithsonian Institution), from two \\
\hline $\mathrm{MgO}$ & 9.28 & 8.37 & 8.89 & 3.03 & 9.22 & separate analytical sessions, are as follows: $\mathrm{SiO}_{2} \pm 0.29$ \\
\hline $\mathrm{CaO}$ & 10.69 & 11.64 & 10.89 & 11.69 & 10.11 & wt. $\%, \mathrm{TiO}_{2} \pm 0.1$ wt. $\%, \mathrm{Al}_{2} \mathrm{O}_{3} \pm 0.08$ wt. $\%, \mathrm{MgO} \pm 0.12$ \\
\hline $\mathrm{MnO}$ & 0.40 & 0.38 & 0.40 & 0.19 & 0.46 & wt. $\%, \mathrm{CaO} \pm 0.11$ wt. $\%, \mathrm{MnO} \pm 0.01$ wt. $\%, \mathrm{FeO} \pm 0.13$ \\
\hline $\mathrm{FeO}$ & 22.07 & 24.51 & 22.42 & 28.43 & 23.18 & wt. $\%, \mathrm{Na}_{2} \mathrm{O} \pm 0.13$ wt. $\%, \mathrm{~K}_{2} \mathrm{O} \pm 0.05$ wt. $\%$, and $\mathrm{F} \pm 0.04$ \\
\hline $\mathrm{Na}_{2} \mathrm{O}$ & 0.79 & 0.26 & 0.91 & 0.49 & 0.98 & wt. $\%$ \\
\hline $\mathrm{K}_{2} \mathrm{O}$ & 0.55 & 0.09 & 0.59 & 1.69 & 0.51 & \\
\hline $\mathrm{H}_{2} \mathrm{O}$ & 1.71 & 1.95 & 1.84 & 1.80 & 1.78 & \\
\hline $\mathrm{F}$ & 0.39 & 0.00 & 0.27 & 0.16 & 0.41 & \\
\hline Total & 97.07 & 99.09 & 99.82 & 99.47 & 100.47 & \\
\hline $\mathrm{Fe}$ & 17.11 & 19.00 & 17.38 & 22.04 & 17.97 & \\
\hline $\mathrm{Mg} \quad$ & 5.60 & 5.05 & 5.36 & 1.83 & 5.56 & \\
\hline $\mathrm{Fe} /(\mathrm{Fe}+\mathrm{Mg})$ & 0.75 & 0.79 & 0.76 & 0.92 & 0.76 & \\
\hline
\end{tabular}


APPENDIX 5. Mica analyses of the Redrock Granite.

Miarolitic biotite granite

\begin{tabular}{|c|c|c|c|c|c|c|c|c|c|c|c|c|c|}
\hline & $\begin{array}{r}\text { NM11 } \\
-5\end{array}$ & $\begin{array}{r}\text { NM11 } \\
-6\end{array}$ & $\begin{array}{r}\text { NM11 } \\
-7\end{array}$ & $\begin{array}{r}\text { NM11 } \\
-8\end{array}$ & $\begin{array}{r}\text { NM11 } \\
-9\end{array}$ & $\begin{array}{r}\text { NM11 } \\
-10\end{array}$ & $\begin{array}{r}\text { NM11 } \\
-11\end{array}$ & $\begin{array}{r}\text { NM11 } \\
-12\end{array}$ & $\begin{array}{r}\text { NM11 } \\
-13\end{array}$ & $\begin{array}{r}\text { NM11 } \\
-14\end{array}$ & $\begin{array}{r}\text { NM11 } \\
-15\end{array}$ & $\begin{array}{r}\text { NM11 } \\
-16\end{array}$ & $\begin{array}{r}\text { NM11 } \\
-17\end{array}$ \\
\hline $\mathrm{SiO}_{2}$ & 46.08 & 45.88 & 47.06 & 47.05 & 45.67 & 46.22 & 49.94 & 50.31 & 45.74 & 45.81 & 46.87 & 47.40 & 45.35 \\
\hline $\mathrm{TiO}_{2}$ & 0.03 & 0.01 & 0.32 & 0.18 & 0.40 & 0.19 & 0.12 & 0.06 & 0.03 & 0.01 & 0.14 & 0.06 & 0.46 \\
\hline $\mathrm{Al}_{2} \mathrm{O}_{3}$ & 36.62 & 36.67 & 28.82 & 30.38 & 29.86 & 29.73 & 29.19 & 28.69 & 37.85 & 36.25 & 28.59 & 31.13 & 31.00 \\
\hline $\mathrm{Cr}_{2} \mathrm{O}_{3}$ & 0.01 & 0.03 & 0.04 & 0.01 & 0.00 & 0.02 & 0.03 & 0.03 & 0.03 & 0.02 & 0.00 & 0.00 & 0.00 \\
\hline $\mathrm{MgO}$ & 0.00 & 0.06 & 0.00 & 0.55 & 0.00 & 0.71 & 1.45 & 1.26 & 0.00 & 1.38 & 0.44 & 0.77 & 0.15 \\
\hline $\mathrm{CaO}$ & 0.01 & 0.02 & 0.03 & 0.03 & 0.03 & 0.04 & 0.17 & 0.14 & 0.01 & 0.00 & 0.02 & 0.02 & 0.06 \\
\hline $\mathrm{MnO}$ & 0.24 & 0.28 & 0.32 & 0.29 & 0.35 & 0.27 & 0.02 & 0.01 & 0.40 & 0.33 & 0.32 & 0.28 & 0.21 \\
\hline $\mathrm{FeO}$ & 1.60 & 1.16 & 6.70 & 5.85 & 6.82 & 6.51 & 4.65 & 5.20 & 0.62 & 1.50 & 6.07 & 5.39 & 6.55 \\
\hline $\mathrm{BaO}$ & 0.01 & 0.00 & 0.04 & 0.00 & 0.00 & 0.02 & 0.02 & 0.01 & 0.01 & 0.01 & 0.03 & 0.00 & 0.00 \\
\hline $\mathrm{Na}_{2} \mathrm{O}$ & 0.32 & 0.26 & 0.13 & 0.07 & 0.25 & 0.22 & 0.14 & 0.13 & 0.24 & 0.30 & 0.09 & 0.09 & 0.27 \\
\hline $\mathrm{K}_{2} \mathrm{O}$ & 11.13 & 11.07 & 11.06 & 10.71 & 10.81 & 10.73 & 9.73 & 9.45 & 10.43 & 10.45 & 10.88 & 10.66 & 10.67 \\
\hline $\mathrm{H}_{2} \mathrm{O}$ & 4.52 & 4.50 & 4.17 & 4.39 & 4.16 & 4.29 & 4.48 & 4.31 & 4.52 & 4.52 & 3.42 & 4.43 & 4.26 \\
\hline $\mathrm{F}$ & 0.00 & 0.00 & 0.32 & 0.00 & 0.31 & 0.11 & 0.00 & 0.34 & 0.03 & 0.03 & 1.84 & 0.00 & 0.16 \\
\hline $\mathrm{Cl}$ & 0.01 & 0.01 & 0.01 & 0.01 & 0.01 & 0.00 & 0.00 & 0.01 & 0.00 & 0.00 & 0.01 & 0.01 & 0.01 \\
\hline Total & 100.58 & 99.94 & 99.01 & 99.52 & 98.66 & 99.07 & 99.94 & 99.95 & 99.91 & 100.60 & 98.71 & 100.24 & 99.16 \\
\hline $\mathrm{Fe}$ & 1.24 & 0.90 & 5.19 & 4.53 & 5.29 & 5.05 & 3.60 & 4.03 & 0.48 & 1.16 & 4.71 & 4.18 & 5.08 \\
\hline $\mathrm{Mg}$ & 0.00 & 0.04 & 0.00 & 0.33 & 0.00 & 0.43 & 0.87 & 0.76 & 0.00 & 0.83 & 0.26 & 0.46 & 0.09 \\
\hline $\mathrm{Fe} /(\mathrm{Fe}+\mathrm{Mg})$ & g) 1.00 & 0.93 & 1.00 & 0.89 & 1.00 & 0.88 & 0.71 & 0.76 & 1.00 & 0.46 & 0.92 & 0.85 & 0.97 \\
\hline
\end{tabular}

Miarolitic biotite granite

\begin{tabular}{lrrrrrrrrrrrrr}
\hline & $\mathrm{NM} 11$ & $\mathrm{NM} 11$ & $\mathrm{NM} 11$ & $\mathrm{NM} 11$ & $\mathrm{NM} 11$ & $\mathrm{NM} 11$ & $\mathrm{NM} 11$ & $\mathrm{NM} 11$ & $\mathrm{NM} 11$ & NM11 \\
& $-\mathrm{n} 7$ & $-\mathrm{n} 8$ & $-\mathrm{n} 9$ & $-\mathrm{n} 10$ & $-\mathrm{n} 11$ & $-\mathrm{n} 12$ & $-\mathrm{n} 13$ & $-\mathrm{n} 14$ & $-\mathrm{n} 15$ & $-\mathrm{n} 23$ & $-\mathrm{n} 24$ & $\begin{array}{r}\text { NM11 } \\
-\mathrm{n} 25\end{array}$ & $\begin{array}{r}\text { NM11 } \\
-\mathrm{n} 26\end{array}$ \\
\hline $\mathrm{SiO}_{2}$ & 48.15 & 46.44 & 46.56 & 43.20 & 38.09 & 45.04 & 48.12 & 41.64 & 48.74 & 45.89 & 47.04 & 45.54 & 42.41 \\
$\mathrm{TiO}_{2}$ & 0.08 & 0.09 & 0.12 & 0.16 & 0.13 & 0.10 & 0.13 & 0.11 & 0.05 & 0.07 & 0.04 & 0.01 & 0.07 \\
$\mathrm{Al}_{2} \mathrm{O}_{3}$ & 25.08 & 27.08 & 26.61 & 22.68 & 16.33 & 27.72 & 31.49 & 24.17 & 27.69 & 25.80 & 30.87 & 24.86 & 19.55 \\
$\mathrm{Cr}_{2} \mathrm{O}_{3}$ & 0.00 & 0.00 & 0.02 & 0.01 & 0.00 & 0.00 & 0.04 & 0.01 & 0.01 & 0.00 & 0.00 & 0.00 & 0.00 \\
$\mathrm{MgO}$ & 1.98 & 1.58 & 1.75 & 1.93 & 2.54 & 1.23 & 0.80 & 1.56 & 1.76 & 1.86 & 0.72 & 1.91 & 2.81 \\
$\mathrm{CaO}$ & 0.38 & 0.28 & 0.28 & 0.40 & 0.50 & 0.27 & 0.20 & 0.41 & 0.34 & 0.36 & 0.05 & 0.36 & 0.48 \\
$\mathrm{MnO}$ & 0.34 & 0.29 & 0.32 & 0.37 & 0.70 & 0.16 & 0.03 & 0.29 & 0.26 & 0.27 & 0.16 & 0.35 & 0.64 \\
$\mathrm{FeO}$ & 10.93 & 8.63 & 9.53 & 17.94 & 20.28 & 7.03 & 3.78 & 8.47 & 8.25 & 8.49 & 5.75 & 11.95 & 19.58 \\
$\mathrm{BaO}$ & 0.00 & 0.02 & 0.00 & 0.04 & 0.05 & 0.01 & 0.04 & 0.04 & 0.00 & 0.03 & 0.00 & 0.03 & 0.05 \\
$\mathrm{Na}{ }_{2} \mathrm{O}$ & 0.46 & 0.29 & 1.29 & 0.43 & 0.75 & 0.29 & 0.13 & 0.34 & 0.27 & 0.24 & 0.09 & 0.33 & 0.53 \\
$\mathrm{~K}_{2} \mathrm{O}$ & 7.50 & 8.38 & 7.49 & 6.51 & 4.60 & 8.48 & 7.93 & 6.61 & 8.01 & 8.51 & 9.62 & 7.80 & 6.59 \\
$\mathrm{H}_{2} \mathrm{O}$ & 4.24 & 4.22 & 4.23 & 3.98 & 3.46 & 4.07 & 4.30 & 3.70 & 4.30 & 4.03 & 4.27 & 4.06 & 3.88 \\
$\mathrm{~F}$ & 0.18 & 0.10 & 0.12 & 0.22 & 0.19 & 0.21 & 0.22 & 0.27 & 0.24 & 0.33 & 0.25 & 0.28 & 0.19 \\
$\mathrm{Cl}$ & 0.02 & 0.02 & 0.02 & 0.02 & 0.07 & 0.02 & 0.02 & 0.06 & 0.02 & 0.02 & 0.01 & 0.02 & 0.03 \\
$\mathrm{Total}$ & 99.34 & 97.40 & 98.35 & 97.88 & 87.70 & 94.62 & 97.23 & 87.67 & 99.92 & 95.90 & 98.88 & 97.48 & 96.82 \\
& & & & & & & & & & & & \\
$\mathrm{Fe}$ & 8.47 & 6.69 & 7.39 & 13.90 & 15.72 & 5.45 & 2.93 & 6.57 & 6.39 & 6.58 & 4.46 & 9.26 & 15.18 \\
$\mathrm{Mg}$ & 1.20 & 0.95 & 1.06 & 1.16 & 1.53 & 0.74 & 0.48 & 0.94 & 1.06 & 1.12 & 0.44 & 1.15 & 1.70 \\
$\mathrm{Fe} /(\mathrm{Fe}+\mathrm{Mg})$ & 0.81 & 0.81 & 0.81 & 0.88 & 0.86 & 0.82 & 0.79 & 0.81 & 0.78 & 0.78 & 0.86 & 0.83 & 0.84
\end{tabular}


APPENDIX 5. Continued.

\begin{tabular}{|c|c|c|c|c|c|c|c|c|c|c|c|c|c|}
\hline & \multicolumn{5}{|c|}{ Hornblende granite } & \multirow[b]{2}{*}{ NM131 } & \multirow[b]{2}{*}{ NM131 } & \multirow[b]{2}{*}{ NM131 } & \multirow[b]{2}{*}{ NM131 } & \multirow[b]{2}{*}{ NM131 } & \multirow{3}{*}{$\begin{array}{r}\text { NM131 } \\
-31\end{array}$} & \multirow[b]{2}{*}{ NM131 } & \multirow[b]{2}{*}{ NM131 } \\
\hline & NM11 & NM11 & NM131 & NM131 & NM131 & & & & & & & & \\
\hline & $-\mathrm{n} 27$ & $-\mathrm{n} 28$ & -17 & -18 & -19 & -20 & -21 & -28 & -29 & -30 & & -44 & -45 \\
\hline $\mathrm{SiO}_{2}$ & 46.14 & 43.06 & 34.21 & 34.58 & 34.14 & 33.76 & 34.47 & 31.89 & 32.74 & 32.14 & 32.10 & 34.03 & 33.87 \\
\hline $\mathrm{TiO}_{2}$ & 0.09 & 0.14 & 4.04 & 3.81 & 4.33 & 4.14 & 3.93 & 3.28 & 3.70 & 2.98 & 3.37 & 3.94 & 4.26 \\
\hline $\mathrm{Al}_{2} \mathrm{O}_{3}$ & 27.10 & 25.30 & 12.41 & 12.70 & 12.55 & 12.47 & 12.83 & 11.61 & 11.75 & 12.42 & 12.49 & 12.29 & 12.40 \\
\hline $\mathrm{Cr}_{2} \mathrm{O}_{3}$ & 0.00 & 0.00 & 0.00 & 0.00 & 0.04 & 0.03 & 0.00 & 0.03 & 0.02 & 0.04 & 0.00 & 0.01 & 0.01 \\
\hline $\mathrm{MgO}$ & 1.68 & 1.64 & 2.73 & 2.76 & 2.74 & 2.78 & 2.82 & 3.06 & 2.90 & 2.95 & 2.85 & 2.93 & 2.80 \\
\hline $\mathrm{CaO}$ & 0.33 & 0.38 & 0.08 & 0.17 & 0.04 & 0.39 & 0.33 & 0.08 & 0.39 & 0.06 & 0.03 & 0.00 & 0.01 \\
\hline $\mathrm{MnO}$ & 0.23 & 0.33 & 0.49 & 0.51 & 0.40 & 0.49 & 0.46 & 0.43 & 0.55 & 0.47 & 0.39 & 0.55 & 0.55 \\
\hline $\mathrm{FeO}$ & 10.99 & 16.34 & 32.66 & 32.75 & 32.45 & 32.37 & 32.10 & 33.47 & 31.99 & 34.01 & 34.04 & 32.47 & 32.63 \\
\hline $\mathrm{BaO}$ & 0.01 & 0.00 & 0.00 & 0.00 & 0.00 & 0.00 & 0.00 & 0.00 & 0.00 & 0.00 & 0.00 & 0.00 & 0.00 \\
\hline $\mathrm{Na}_{2} \mathrm{O}$ & 1.12 & 0.31 & 0.10 & 0.12 & 0.07 & 0.10 & 0.10 & 0.04 & 0.21 & 0.08 & 0.04 & 0.05 & 0.06 \\
\hline $\mathrm{K}_{2} \mathrm{O}$ & 7.97 & 6.77 & 8.95 & 8.68 & 9.16 & 8.25 & 8.39 & 8.44 & 7.56 & 8.40 & 8.63 & 9.21 & 9.19 \\
\hline $\mathrm{H}_{2} \mathrm{O}$ & 4.23 & 4.06 & 3.26 & 3.16 & 3.13 & 3.25 & 3.17 & 3.29 & 3.15 & 3.32 & 3.32 & 3.19 & 3.30 \\
\hline $\mathrm{F}$ & 0.18 & 0.17 & 0.59 & 0.88 & 0.91 & 0.55 & 0.84 & 0.18 & 0.55 & 0.20 & 0.23 & 0.71 & 0.47 \\
\hline $\mathrm{Cl}$ & 0.03 & 0.04 & 0.45 & 0.43 & 0.40 & 0.46 & 0.41 & 0.39 & 0.41 & 0.44 & 0.44 & 0.45 & 0.51 \\
\hline Total & 100.10 & 98.55 & 99.96 & 100.56 & 100.36 & 99.05 & 99.84 & 96.19 & 95.90 & 97.52 & 97.93 & 99.80 & 100.04 \\
\hline $\mathrm{Fe}$ & 8.52 & 12.67 & 25.31 & 25.39 & 25.16 & 25.09 & 24.89 & 25.94 & 24.80 & 26.36 & 26.39 & 25.17 & 25.29 \\
\hline $\mathrm{Mg}$ & 1.01 & 0.99 & 1.65 & 1.67 & 1.65 & 1.68 & 1.70 & 1.84 & 1.75 & 1.78 & 1.72 & 1.77 & 1.69 \\
\hline $\mathrm{Fe} /(\mathrm{Fe}+\mathrm{N}$ & Ig) 0.84 & 0.89 & 0.90 & 0.90 & 0.90 & 0.90 & 0.90 & 0.90 & 0.90 & 0.90 & 0.90 & 0.90 & 0.90 \\
\hline
\end{tabular}

Biotite-hornblende granite

\begin{tabular}{|c|c|c|c|c|c|c|c|c|c|c|c|}
\hline & $\begin{array}{r}\text { NM93- } \\
98-24\end{array}$ & $\begin{array}{r}\text { NM93- } \\
98-26\end{array}$ & $\begin{array}{l}\text { NM93- } \\
98-27\end{array}$ & $\begin{array}{r}\text { NM93- } \\
98-28\end{array}$ & $\begin{array}{r}\text { NM93- } \\
98-29\end{array}$ & $\begin{array}{c}\text { NM93- } \\
98-36\end{array}$ & $\begin{array}{r}\text { NM93- } \\
98-37\end{array}$ & $\begin{array}{r}\text { NM93- } \\
98-51\end{array}$ & $\begin{array}{r}\text { NM93- } \\
98-52\end{array}$ & $\begin{array}{r}\text { NM93- } \\
98-59\end{array}$ & $\begin{array}{r}\text { NM93- } \\
98-55\end{array}$ \\
\hline $\mathrm{SiO}_{2}$ & 34.08 & 33.22 & 33.67 & 33.19 & 33.38 & 34.20 & 32.41 & 33.85 & 34.26 & 34.29 & 33.55 \\
\hline $\mathrm{TiO}_{2}$ & 3.69 & 3.51 & 3.80 & 3.33 & 3.47 & 3.91 & 4.03 & 3.84 & 3.87 & 3.88 & 3.61 \\
\hline $\mathrm{Al}_{2} \mathrm{O}_{3}$ & 12.48 & 12.73 & 12.18 & 12.92 & 12.10 & 12.54 & 11.78 & 12.31 & 12.46 & 12.42 & 12.42 \\
\hline $\mathrm{Cr}_{2} \mathrm{O}_{3}$ & 0.05 & 0.00 & 0.03 & 0.00 & 0.01 & 0.01 & 0.00 & 0.03 & 0.00 & 0.02 & \\
\hline $\mathrm{MgO}$ & 4.12 & 5.00 & 3.87 & 4.06 & 3.69 & 3.53 & 3.24 & 3.34 & 3.51 & 3.54 & 3.61 \\
\hline $\mathrm{CaO}$ & 0.10 & 0.17 & 0.13 & 0.12 & 0.13 & 0.16 & 0.10 & 0.02 & 0.08 & 0.08 & 0.22 \\
\hline $\mathrm{MnO}$ & 0.37 & 0.38 & 0.37 & 0.36 & 0.37 & 0.31 & 0.38 & 0.36 & 0.34 & 0.27 & 0.38 \\
\hline $\mathrm{FeO}$ & 31.42 & 32.59 & 31.74 & 32.77 & 31.83 & 31.54 & 31.70 & 32.56 & 32.56 & 32.16 & 32.80 \\
\hline $\mathrm{BaO}$ & 0.00 & 0.00 & 0.00 & 0.00 & 0.00 & 0.00 & 0.00 & 0.00 & 0.00 & 0.00 & \\
\hline $\mathrm{Na}_{2} \mathrm{O}$ & 0.10 & 0.16 & 0.14 & 0.07 & 0.11 & 0.11 & 0.16 & 0.07 & 0.08 & 0.11 & 0.12 \\
\hline $\mathrm{K}_{2} \mathrm{O}$ & 9.14 & 7.71 & 8.98 & 8.17 & 8.95 & 9.01 & 8.88 & 9.26 & 8.91 & 9.12 & 8.53 \\
\hline $\mathrm{H}_{2} \mathrm{O}$ & 3.36 & 3.39 & 3.36 & 3.43 & 3.34 & 3.40 & 3.41 & 3.48 & 3.40 & 3.37 & 1.62 \\
\hline $\mathrm{F}$ & 0.40 & 0.36 & 0.34 & 0.22 & 0.25 & 0.31 & 0.00 & 0.11 & 0.37 & 0.40 & 0.25 \\
\hline $\mathrm{Cl}$ & 0.46 & 0.41 & 0.45 & 0.41 & 0.51 & 0.47 & 0.46 & 0.46 & 0.40 & 0.44 & \\
\hline Total & 99.76 & 99.62 & 99.05 & 99.03 & 98.14 & 99.49 & 96.54 & 99.68 & 100.23 & 100.09 & 97.11 \\
\hline $\mathrm{Fe}$ & 24.36 & 25.26 & 24.60 & 25.40 & 24.67 & 24.45 & 24.58 & 25.24 & 25.24 & 24.93 & 25.43 \\
\hline $\mathrm{Mg}$ & 2.48 & 3.02 & 2.33 & 2.45 & 2.22 & 2.13 & 1.96 & 2.02 & 2.12 & 2.14 & 2.18 \\
\hline $\mathrm{Fe} /(\mathrm{Fe}+\mathrm{Mg}$ & g) 0.86 & 0.84 & 0.86 & 0.86 & 0.87 & 0.87 & 0.88 & 0.88 & 0.88 & 0.88 & 0.88 \\
\hline
\end{tabular}

Analytical error, based on 12 replicate analyses of standard reference material Biot5. Errors for $\mathrm{CaO}$ and $\mathrm{Na}_{2} \mathrm{O}$ were obtained from Kakanui hornblende due to low concentrations in Biot5. Data from 2 separate analytical sessions are as follows: $\mathrm{SiO}_{2} \pm 0.30$ wt. $\%, \mathrm{TiO}_{2} \pm 0.1 \mathrm{wt} . \%, \mathrm{Al}_{2} \mathrm{O}_{3} \pm 0.10$ wt. $\%, \mathrm{MgO} \pm 0.11$ wt. $\%$, $\mathrm{CaO} \pm 0.11$ wt. $\%, \mathrm{MnO} \pm 0.02$ wt. $\%, \mathrm{FeO} \pm 0.10$ wt. $\%, \mathrm{Na}_{2} \mathrm{O} \pm 0.13$ wt. $\%, \mathrm{~K}_{2} \mathrm{O} \pm 0.03$ wt. $\%, \mathrm{~F} \pm 0.04$ wt. $\%$, and $\mathrm{Cl} \pm 0.01$ wt. $\%$. 